HÁTYLAS FELYPE ZANETI DE AZEVEDO

\title{
SINALIZAÇÃO MEDIADA PELA ANGIOTENSINA II \\ EM UM MODELO DE GLIOBLASTOMA MULTIFORME: \\ USO DA GENÔMICA FUNCIONAL NA IDENTIFICAÇÃO \\ DO PAPEL DOS RECEPTORES AT1 E AT2
}

Dissertação apresentada ao Programa de PósGraduação Interunidades em Biotecnologia USP/Instituto Butantan/IPT, para obtenção do

Título de Mestre em Biotecnologia 
HÁTYLAS FELYPE ZANETI DE AZEVEDO

\section{SINALIZAÇÃO MEDIADA PELA ANGIOTENSINA II \\ EM UM MODELO DE GLIOBLASTOMA MULTIFORME: \\ USO DA GENÔMICA FUNCIONAL NA IDENTIFICAÇÃO \\ DO PAPEL DOS RECEPTORES AT1 E AT2}

Dissertação apresentada ao Programa de PósGraduação Interunidades em Biotecnologia USP/Instituto Butantan/IPT, para Obtenção do Título de Mestre em Biotecnologia

Área de concentração: Biotecnologia

Orientador: Prof. Dr. Carlos Alberto Moreira-Filho

Versão original 
DADOS DE CATALOGAÇÃO NA PUBLICAÇÃO (CIP)

Serviço de Biblioteca e Informação Biomédica do

Instituto de Ciências Biomédicas da Universidade de São Paulo

(c) reprodução total

Azevedo, Hátylas Felype Zaneti de.

Sinalização mediada pela Angiotensina II em um modelo de glioblastoma multiforme: uso da genômica funcional na identificação do papel dos receptores AT1 e AT2 / Hátylas Felype Zaneti de Azevedo. - São Paulo, 2012.

Orientador: Prof. Dr. Carlos Alberto Moreira Filho.

Dissertação (Mestrado) - Universidade de São Paulo. Instituto de Ciências Biomédicas. Programa de Pós-Graduação Interunidades em Biotecnologia USP/IPT/Instituto Butantan. Área de concentração: Biotecnologia. Linha de pesquisa: Genômica Funcional.

Versão do título para o inglês: Transcriptome profile induced by Angiotensin II in glioma cells: potential insights into the role of AT1 and AT2 receptors.

1. Genômica 2. Oncologia 3. Biotecnologia 4. Bioinformática 5. Biologia molecular I. Moreira Filho, Prof. Dr. Carlos Alberto II. Universidade de São Paulo. Instituto de Ciências Biomédicas. Programa de Pós-Graduação Interunidades em Biotecnologia USP/IPT/Instituto Butantan III. Título. 
Título da Dissertação:

Orientador(a):
Sinalização mediada pela Ang II em um modelo de glioblastoma multiforme: Uso da genômica funcional na identificação do papel dos receptores AT1 e AT2

Prof. Dr. Carlos Alberto Moreira-Filho

A Comissão Julgadora dos Trabalhos de Defesa da Dissertação de Mestrado, em sessão pública realizada a ..................., considerou o(a)

\section{() Aprovado(a) ( ) Reprovado(a)}

Examinador(a): Assinatura:

Nome:

Instituição:

Examinador(a): Assinatura:

Nome:

Instituição:

Presidente: Assinatura:

Nome:

Instituição: 


\section{AGRADECIMENTOS}

Ao Professor Carlos Alberto Moreira-Filho por toda orientação e oportunidade de aprendizado que contribuíram para o meu crescimento profissional e pessoal.

À Paula pela companhia, carinho e incentivo para nunca desistir dos meus sonhos.

A minha Família por me apoiar em todos os momentos e por serem meus exemplos de vida.

À equipe do Laboratório de Genômica Pediátrica - Dra. Silvia Y. Bando, Dra. Patricia L. Ramos (atualmente na UNIFESP), Thais Baudracco, Priscila lamashita e Leandro Ferreira - pelo aprendizado, ajuda nos experimentos e discussões de trabalho.

À Fernanda Macaferri da Fonseca e Thais Scudelletti, do LIM-36 HC-FMUSP, pelo apoio durante a realização deste trabalho.

Aos colegas Beatriz R. Corradini, Vinicius G. Cerezer, Roberta L. Dutra, Ana Carolina D. Teixeira pela companhia e amizade.

Aos Drs. Renato Faro e Carlos Melo, do Aché Laboratórios, pela compreensão sobre a importância da pós-graduação para o meu desenvolvimento profissional.

Aos Professores Roger Chammas e Sueli K. Nagahashi Marie da FMUSP pelo fornecimento de reagentes e células para a realização deste trabalho.

Ao Professor André Fujita, do IME-USP, pelo auxílio nas análises estatísticas e de bioinformática.

Ao Marcos, Fábia e Eliane, da Secretaria do Programa de Pós-Graduação Interunidades em Biotecnologia, pelo auxílio nos procedimentos administrativos relacionados ao programa de pós-graduação.

Às Professoras Eugênia Costanzi-Strauss, Glaucia Santelli e Alison Colquhoun, do ICB-USP, pelas contribuições científicas em minha Qualificação de Mestrado.

Ao CNPQ pela concessão da bolsa de mestrado. 
"Todo o futuro da nossa espécie, todo o governo das sociedades, toda a prosperidade moral e material das nações dependem da ciência, como a vida do homem depende do ar. Ora, a ciência é toda observação, toda exatidão, toda verificação experimental. Perceber os fenômenos, discernir as relações, comparar as analogias e as dessemelhanças, classificar as realidades, e induzir as leis, eis a ciência; eis, portanto, o alvo que a educação deve ter em mira. Espertar na inteligência nascente as faculdades cujo concurso se requer nesses processos de descobrir e assimilar a verdade, é o a que devem tender os programas e os métodos de ensino." 


\section{RESUMO}

AZEVEDO, H. Sinalização mediada pela angiotensina II em um modelo de glioblastoma multiforme: Uso da genômica funcional na identificação do papel dos receptores AT1 e AT2. 2012. 90 f. Dissertação (Mestrado em Biotecnologia) Instituto de Ciências Biomédicas, Universidade de São Paulo, São Paulo, 2012.

Glioblastoma multiforme é um tipo comum e agressivo de tumor cerebral primário, com um mau prognóstico após a cirurgia devido ao seu potencial altamente infiltrativo. A expressão dos receptores AT1 e AT2 da Angiotensina II (Ang II) em astrocitomas foi anteriormente associada a um pior prognóstico. Para investigar os mecanismos moleculares da ação da Ang II em gliomas, o transcriptoma comparativo de gliomas tratados com Ang II foi analisado. Células C6 de glioma de rato foram cultivadas em condições adequadas e tratadas com Ang II e antagonistas específicos de AT1 e AT2. O RNA total foi isolado nos intervalos de três e seis horas e submetido ao protocolo de DNA microarray. Os genes diferencialmente expressos foram obtidos e submetidos a análises subsequentes de enriquecimento funcional, diagramas de Venn e redes de interação. As alterações no transcriptoma observadas a partir do tratamento com Ang II revelaram genes envolvidos na mitose, ciclo celular, ubiquitinação de proteínas, reparo do DNA, doenças neurológicas, apoptose, crescimento celular, fosforilação, transporte de proteínas e migração celular. O bloqueio dos receptores AT1 ou AT2 alterou a expressão de genes envolvidos na mitose, ciclo celular, diferenciação, apoptose, citoesqueleto de actina, fosforilação, adesão focal, adesão celular e vias em câncer. Além disso, de acordo com os perfis de expressão gênica obtidos, as vias de sinalização hiper-representadas foram PI3K, ErbB, mTOR, MAPK, Notch, VEGF, neurotrofinas, insulina, Wnt, TGF- $\beta$ e p53. Este estudo revelou como o transcriptoma de células de glioma é modificado pela ação da Ang II. Embora a transdução de sinal de AT2 seja distinta da observada em AT1, ambas apresentam categorias funcionais em comum que podem estar relacionadas ao pior prognóstico observado em pacientes cujos gliomas expressem esses receptores.

Palavras-chave: Glioblastoma Multiforme. Linhagem celular C6. DNA microarrays. Angiotensina II. Genômica Funcional. 


\begin{abstract}
AZEVEDO, H. Transcriptome profile regulated by Angiotensin II in glioma cells: potential insights into the role of AT1 and AT2 receptors. 2012. 90 p. Masters thesis (Biotechnology) - Instituto de Ciências Biomédicas, Universidade de São Paulo, São Paulo, 2012.
\end{abstract}

Glioblastoma multiform is a common and aggressive type of primary brain tumor in humans, with a poor prognosis after surgery due to its highly infiltrative potential. The expression of AT1 and AT2 receptors of Angiotensin II (Ang II) in human astrocytomas was previously associated with a worse prognosis. To investigate the molecular mechanisms of Ang II action in gliomas, the comparative transcriptomic profile of glioma cells exposed to Ang II was evaluated. C6 rat glioma cells were cultured under proper conditions and treated with Ang II and specific antagonists of AT1 and AT2. Total RNA was isolated at the intervals of three and six hours and submitted to DNA microarray protocol for gene expression analysis. The differentially expressed genes were obtained and submitted to functional enrichment, Venn diagram and transcriptome network analyzes. Most of the gene alterations seen after Ang II treatment revealed genes involved in mitosis, cell cycle, protein ubiquitination, DNA repair, neurologic diseases, apoptosis, cell growth and protein phosphorylation. DNA microarray data analysis indicated that blocking AT1 or AT2 changed the expression of genes involved in mitosis, cell cycle and growth, cell proliferation, cell differentiation, apoptosis, cell adhesion, regulation of actin cytoskeleton, cell migration, focal and cell adhesion protein ubiquitination and pathways in cancer. Additionally, according to the gene expression profiles activated extent, the signal transduction pathways overrepresented were ErbB, mTOR, MAPK, Notch, neurotrophin, insulin, Wnt, TGF- $\beta$ and p53. Taken together, our results provide insights into how the transcriptome of glioma cells is affected by Ang II. Moreover, although the signal transduction of AT2 is distinct from the observed for AT1, they present functional categories in common that may be underlying the worst prognosis observed in gliomas expressing Ang II receptors.

Keywords: Glioblastoma. C6 rat cell line. Angiotensin II. Functional genomics. DNA microarray. 


\section{LISTA DE ILUSTRAÇÕES}

Figura 1 - Pipeline de bioinformática utilizado para a obtenção dos insights biológicos a partir dos genes diferencialmente expressos...................................21

Figura 2 - Análise da integridade do RNA extraído de células C6. .....................22

Figura 3 - A expressão de Mmp9 e Ccl2 é regulada pela Ang II em gliomas.......24

Figura 4 - Processos biológicos categorizados segundo GO após 3 horas de tratamento com Ang II..............................................................................26

Figura 5 - Temas hiper-representados em KEGG após 3 horas de tratamento com Ang II. ..........................................................................................27

Figura 6 - Processos biológicos categorizados segundo GO após 6 horas de tratamento com Angiotensina II....................................................................28 Figura 7 - Temas hiper-representados em KEGG após 6 horas de tratamento com Ang II. ...................................................................................................29 Figura 8 - Processos biológicos categorizados segundo GO e mediados pelo receptor AT1 no intervalo de 3 horas. ................................................................. Figura 9 - Temas hiper-representados em KEGG e modulados via receptor AT1

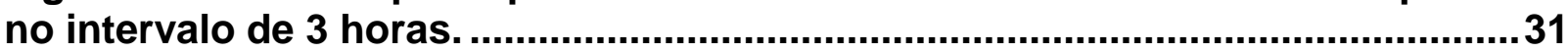
Figura 10 - Processos biológicos categorizados segundo GO e mediados pelo receptor AT1 no intervalo de 6 horas. ............................................................33 Figura 11 - Temas hiper-representados em KEGG e modulados via receptor AT1 no intervalo de 6 horas. .................................................................................. Figura 12 - Processos biológicos categorizados segundo GO e mediados pelo receptor AT2 no intervalo de 3 horas..................................................................36 Figura 13 - Temas hiper-representados em KEGG e modulados via receptor AT2 no intervalo de 3 horas.

Figura 14 - Processos biológicos categorizados segundo GO e mediados pelo receptor AT2 no intervalo de 6 horas. 38

Figura 15 - Temas hiper-representados em KEGG modulados via receptor AT2

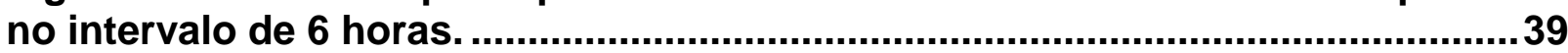

Figura 16 - Diagramas de Venn entre as mesmas comparações em 3 e 6 h........40 Figura 17 - Diagrama de Venn entre os resultados para Ang II, AT1 e AT2. .......42 Figura 18 - Enriquecimento funcional dos genes sobrepostos entre as comparações Ang x Controle e Ang + Los x Ang. ...............................................43 Figura 19 - Enriquecimento funcional dos genes sobrepostos entre as comparações Ang x Controle e Ang + PD x Ang...........................................44 Figura 20 - Enriquecimento funcional dos genes sobrepostos entre as comparações Ang + Los x Ang e Ang + PD x Ang ……......................................45 Figura 21 - Interatoma obtido a partir das proteínas codificadas por genes diferencialmente expressos encontrados na comparação Ang x Controle $3 \mathrm{~h} . . .50$ Figura 22 - Interatoma obtido a partir das proteínas codificadas por genes diferencialmente expressos encontrados na comparação Ang x Controle $6 \mathrm{~h}$....51 Figura 23 - Interatoma obtido a partir das proteínas codificadas por genes diferencialmente expressos encontrados na comparação Ang+Los x Ang 3h. ..52 Figura 24 - Interatoma obtido a partir das proteínas codificadas por genes diferencialmente expressos encontrados na comparação Ang+Los x Ang $6 \mathrm{~h} . . .53$ Figura 25 - Interatoma obtido a partir das proteínas codificadas por genes diferencialmente expressos encontrados na comparação Ang+PD x Ang $3 \mathrm{~h} \ldots . .54$ Figura 26 - Interatoma obtido a partir das proteínas codificadas por genes diferencialmente expressos encontrados na comparação Ang+PD x Ang $6 \mathrm{~h} . . .55$ Figura 27 - Validação dos resultados de DNA microarray por qPCR. 


\section{LISTA DE QUADROS}

Quadro 1 - Classificação de astrocitomas - OMS

Quadro 2 - Primers utilizados nas reações de qPCR dos genes Ccl2 e Mmp9..23 Quadro 3 - Sobreposição dos resultados encontrados para as mesmas comparações nos intervalos de 3 e 6 horas.

Quadro 4 - Lista de Hubs encontrados em cada interatoma..............................47

Quadro 5 - Hubs encontrados nas análises dos interatomas e suas possíveis

funções biológicas e associação com gliomas.

Quadro 6 - Genes diferencialmente expressos nas análises de DNA microarray que foram selecionados para posterior validação por qPCR

Quadro S1 - Genes diferencialmente expressos enriquecidos em KEGG no intervalo de 3 horas de tratamento com Ang II.............................................79 Quadro S2 - Genes diferencialmente expressos enriquecidos em GO no intervalo de 3 horas de tratamento com Ang II............................................... 80 Quadro S3 - Genes diferencialmente expressos enriquecidos em KEGG no intervalo de 6 horas de tratamento com Ang II................................................. Quadro S4 - Genes diferencialmente expressos enriquecidos em GO no intervalo de 6 horas de tratamento com Ang II.................................................. Quadro S5 - Genes diferencialmente expressos enriquecidos em KEGG no intervalo de 3 horas de tratamento com Ang II e Losartan.................................84 Quadro S6 - Genes diferencialmente expressos enriquecidos em GO no intervalo de 3 horas de tratamento com Ang II e Losartan.................................85 Quadro S7 - Genes diferencialmente expressos enriquecidos em KEGG no intervalo de 6 horas de tratamento com Ang II e Losartan..................................86 Quadro S8 - Genes diferencialmente expressos enriquecidos em GO no intervalo de 6 horas de tratamento com Ang II e Losartan................................87 Quadro S9 - Genes diferencialmente expressos enriquecidos em KEGG no intervalo de 3 horas de tratamento com Ang II e PD123319..............................88 Quadro S10 - Genes diferencialmente expressos enriquecidos em GO no intervalo de 3 horas de tratamento com Ang II e PD123319...............................89 Quadro S11 - Genes diferencialmente expressos enriquecidos em KEGG no intervalo de 6 horas de tratamento com Ang II e PD123319.............................90 Quadro S12 - Genes diferencialmente expressos enriquecidos em GO no intervalo de 6 horas de tratamento com Ang II e PD123319. .91 
1 INTRODUÇÃO

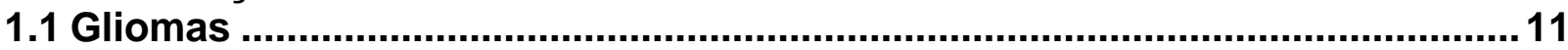

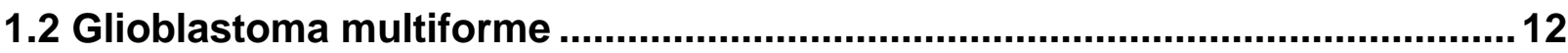

1.3 Modelos experimentais de glioblastoma multiforme ....................................13

1.4 A sinalização mediada pela Angiotensina II e seu papel em tumores .............14

1.5 Estudos de genômica funcional em gliomas ...................................................15

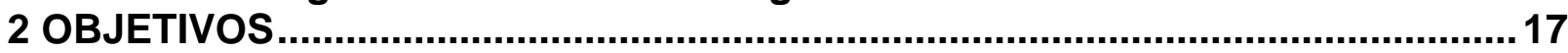

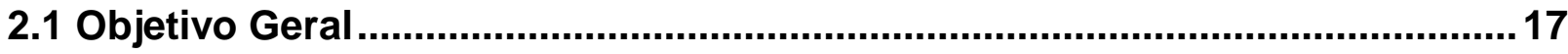

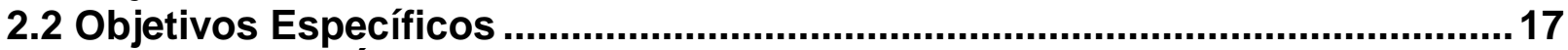

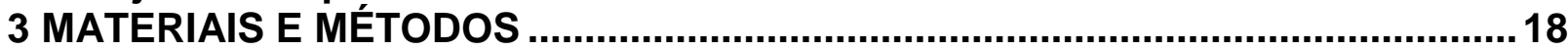

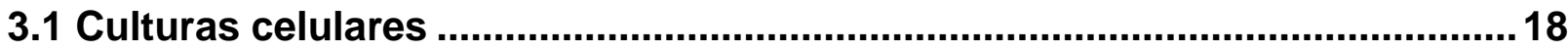

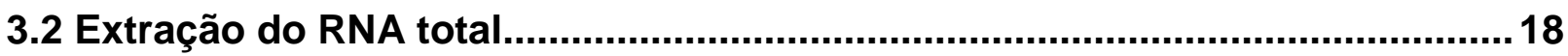

3.3 Microarray de oligonucleotídeos de DNA ……............................................19

3.3.1. Amplificação e marcação fluorescente do RNA .........................................19

3.3.2 Hibridização das lâminas de DNA microarray e aquisição dos dados ........19

3.3.3 Processamento e análise dos resultados de DNA microarray obtidos ....... 20

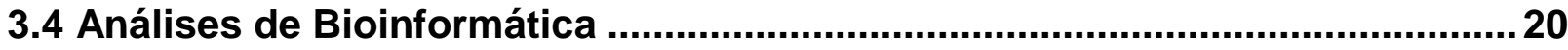

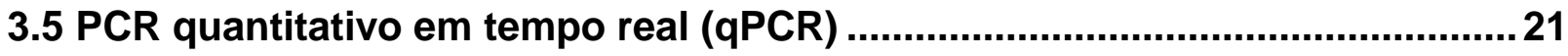

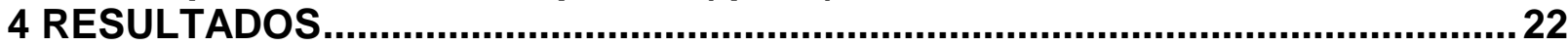

4.1 Padronizações das culturas celulares e do modelo utilizado .........................22

4.2 Análise da qualidade da hibridização dos DNA microarrays .........................24

4.3 Análise transcriptômica da transdução de sinal promovida pela Ang II........25

4.3.1 Intervalo de 3 horas de tratamento com Ang II...........................................25

4.3.2 Intervalo de 6 horas de tratamento com Angiotensina II..........................27

4.4 Análise transcriptômica da transdução de sinal ativada pelo receptor AT1 .30

4.4.1 Intervalo de 3 horas de tratamento com Ang II e Losartan.............................30

4.4.2 Intervalo de 6 horas de tratamento com Ang II e Losartan...........................32

4.5 Análise transcriptômica da transdução de sinal ativada pelo receptor AT2 .34

4.5.1 Intervalo de 3 horas de tratamento com Ang II e PD123319.........................35

4.5.2 Intervalo de 6 horas de tratamento com Ang II e PD123319........................ 37

4.6 Análises dos resultados dos perfis diferenciais de expressão gênica por

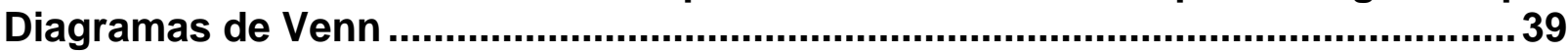

4.7 Redes de Interatoma ............................................................................... 46

4.8 Validação dos resultados de DNA microarray por qPCR ................................56

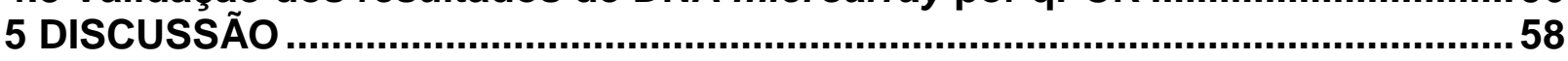

5.1 Análise funcional do transcriptoma induzido pela ativação global dos

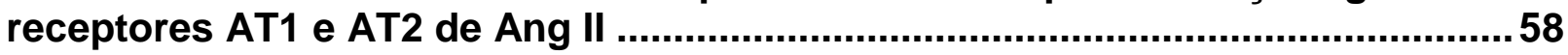

5.2 Análise funcional do transcriptoma regulado pelo receptor AT1 de Ang II ...62

5.3 Análise funcional do transcriptoma regulado pelo receptor AT2 ...................63

5.4 Similaridades e diferenças dos papéis dos receptores AT1 e AT2 ................64

5.5 Análise integrada da Ang II sobre o transcriptoma das células C6 .................65

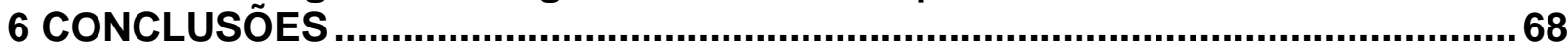

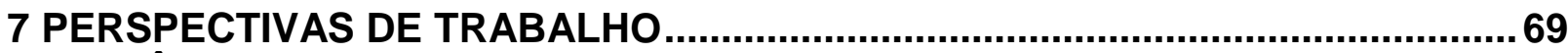

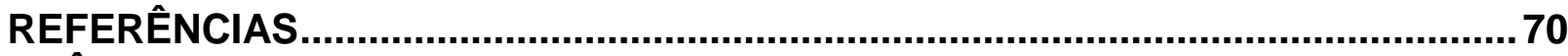

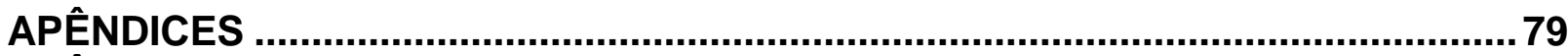

APÊNDICE A - Quadros suplementares contendo os genes presentes em cada

tema hiper-representado nas comparações realizadas ..........................................79 


\section{INTRODUÇÃO}

\subsection{Gliomas}

Os gliomas derivados de astrocitomas são os tumores cerebrais primários mais comuns em humanos, representando $60 \%$ de todos os tumores cerebrais primários (DEANGELIS, 2001). Os tratamentos convencionais para a maioria dos gliomas malignos, incluindo quimioterapia, radioterapia e cirurgia, são reconhecidamente medidas paliativas, sendo que o tempo médio de sobrevida apresentou pouca melhora ao longo dos últimos 25 anos (WONG, 2007).

Os astrocitomas são gliomas originados de astrócitos. Eles podem ser difusos e pilocíticos. Os astrocitomas pilocíticos ocorrem em localizações especiais como no cerebelo e nervo óptico. Predominam em crianças e são considerados de grau de malignidade baixo. Os astrocitomas difusos ocorrem principalmente em hemisférios cerebrais de adultos e são os tumores mais comuns originados de células da glia. São chamados difusos porque não possuem boa delimitação e apresentam potencial infiltrativo. Além disso, tendem a progredir com o tempo a graus mais elevados de malignidade, o que torna seu prognóstico pior (PERRY, 2003).

A classificação dos astrocitomas tem grande importância na prática clínica porque está relacionada com o prognóstico dos pacientes. A classificação mais utilizada para os astrocitomas é a da Organização Mundial da Saúde - OMS (KHLEIUES, 2002), a qual foi adotada neste trabalho. Essa classificação é baseada em aspectos histopatológicos relacionados ao grau de malignidade como atipias nucleares, índice mitótico, proliferação endotelial e necrose. Conforme o número de achados histopatológicos, os astrocitomas são classificados como indicado no Quadro 1.

\section{Quadro 1 - Classificação de astrocitomas - OMS}

\begin{tabular}{|lll|}
\hline Grau & Classificação & Sobrevida \\
Grau I & Astrocitoma pilocítico & $>5$ anos \\
Grau II & Astrocitoma difuso de baixo grau & $>5$ anos \\
Grau III & Astrocitoma anaplásico & 2 a 5 anos \\
Grau IV & Glioblastoma multiforme & $<1$ ano \\
\hline
\end{tabular}




\subsection{Glioblastoma multiforme}

O glioblastoma multiforme (GBM) é o tipo de astrocitoma mais comum e maligno, com um prognóstico desolador. Durante os últimos 25 anos, não ocorreram avanços significativos no desenvolvimento de tratamentos efetivos para o GBM, sendo que atualmente $80 \%$ dos pacientes com GBM submetidos à ressecção cirúrgica, radioterapia e quimioterapia apresentam um tempo médio de sobrevida de 12 meses (DA FONSECA et al., 2006).

A neurocirurgia ainda é um elemento fundamental da terapia padrão para pacientes com glioma de alto grau. É bem reconhecido que a cirurgia pode, pelo menos temporariamente, melhorar a qualidade de vida de uma proporção significativa desses pacientes (HENRIKSSON et al., 2011). Entretanto, devido ao seu acesso cirúrgico restrito e a alta taxa de morbidade pós-operatória, a ressecção cirúrgica completa dos GBMs é difícil. A radioterapia intraoperatória também é utilizada. Contudo, seus resultados não são satisfatórios e a sobrevida é equivalente ao tratamento convencional (HARGRAVE et al., 2006). A radioterapia também pode ser associada ao tratamento quimioterápico com o uso da droga temozolomida, um agente alquilante e citotóxico (STUPP et al., 2005). A temozolomida parece funcionar sensibilizando as células do tumor à radiação (CHAMBERLAIN, 2006). Entretanto, esse quimioterápico apresenta eficácia limitada, sendo que a sobrevida global média permanece baixa (STUPP et al., 2009).

Em síntese, a cirurgia, a radioterapia e a quimioterapia alcançam ainda resultados limitados no que tange à sobrevida e à melhoria da qualidade de vida dos pacientes portadores de GBMs. Assim, o esclarecimento dos mecanismos moleculares e a identificação de novos alvos terapêuticos associados a essa classe de tumores é fundamental para o tratamento medicamentoso efetivo desses pacientes. 


\subsection{Modelos experimentais de glioblastoma multiforme}

Os estudos realizados em modelos experimentais permitem obter informações sobre o comportamento morfológico e funcional do tumor, constituindo um passo importante para a descoberta de novas alternativas terapêuticas para os GBMs. Há uma necessidade em neurooncologia experimental de modelos animais que possam ser utilizados para avaliar a eficácia de terapias inovadoras, sendo que modelos derivados de roedores têm sido utilizados nesse sentido (MAGGIO et al., 1996).

As células C6, linhagem de glioblastoma de ratos Wistar, são frequentemente utilizadas em estudos relacionados à proliferação, invasão e migração em gliomas (BARTH et al., 1998). Sibenaller et al. (2005) demonstraram que dentre as linhagens de glioma de rato C6, 9L, F98, e RG2, a linhagem celular C6 apresentou maior similaridade genética ao relatado em tumores cerebrais humanos. Ademais, Grobben et al. (2002) demonstraram que o modelo utilizando células C6 transplantadas em ratos Wistar apresenta características mais próximas aos glioblastomas humanos quando comparado a outras linhagens celulares de gliomas.

As células C6 são também particularmente interessantes por apresentarem resposta proliferativa descrita a Angiotensina II (RIVERA et al., 2001). A Angiotensina II (Ang II), atuando por meio de seus receptores, pode desencadear processos biológicos relevantes para o desenvolvimento do tumor tais como a proliferação celular, a angiogênese e a evasão da apoptose (ESCOBAR et al., 2004). De fato, o bloqueio do receptor AT1 da Ang II foi capaz de diminuir a síntese de fatores de crescimento e induzir a apoptose em células de glioma C6 (ARRIETA et al., 2005). Além disso, a expressão dos receptores da Ang II está associada a piores prognósticos em astrocitomas humanos (ARRIETA et al., 2008). Entretanto, os mecanismos moleculares associados a essa observação permanecem elusivos e portanto estudos nessa área são apropriados. Assim, a linhagem C6 torna-se um modelo adequado para estudos in vitro e in vivo do mecanismo de ação da Ang II em glioblastomas, dado o seu potencial de correlação dos resultados encontrados entre modelos animais e gliomas humanos, além de sua resposta descrita à Ang II. 


\subsection{A sinalização mediada pela Angiotensina II e seu papel em tumores}

O sistema renina-angiotensina (SRA) foi descrito canonicamente pela sua participação no sistema cardiovascular e na regulação do balanço hídrico e eletrolítico. Entretanto, durante a última década, novas funções não clássicas foram estabelecidas para a Ang II, tais como a regulação do crescimento, proliferação e migração celular, da apoptose, da inflamação, da diferenciação e da angiogênese, o que sugere que esse peptídeo pode exercer um papel importante no câncer (DOMINSKA, 2008).

A Ang II atua por meio de dois subtipos de receptores, AT1 e AT2, ambos pertencentes à família dos receptores de sete domínios transmembrânicos acoplados à proteína G (KASCHINA; UNGER, 2003). Aparentemente, a ativação desses receptores apresenta funções antagônicas, relacionadas a mecanismos distintos de sinalização celular (MIURA et al., 2010). Muitas funções prótumorigênicas foram atribuídas à ativação do receptor AT1, sendo que a inibição da sinalização promovida por esse receptor é capaz de reduzir o crescimento tumoral e a angiogênese em um modelo murino (FUJITA et al., 2002). Em contrapartida, algumas funções anti-tumorigênicas foram descritas para o receptor AT2, tais como a ativação da apoptose (YAMADA et al., 1996) e a inibição do crescimento tumoral e da angiogênese (HORIUCHI et al., 1999). Entretanto, alguns autores questionam essa função antagônica dos receptores AT1 e AT2, pois o receptor AT2 parece ser importante também para o desenvolvimento tumoral (CLERE et al., 2010).

Como descrito anteriormente, a proposta do uso terapêutico de inibidores do SRA em tumores deriva da observação por vários autores da participação do SRA na progressão de tumores. O bloqueio desse sistema é capaz de reduzir a proliferação, a metástase, o crescimento tumoral e a angiogênese (ATEEQ; TOMLINS, CHINNAIYAN, 2009; HERR, 2008; RHODES, 2009). Esses achados levaram a utilização de inibidores da enzima conversora de Ang II e do receptor AT1 como alternativas terapêuticas em tumores. Em gliomas, foi demonstrado que o Losartan, um antagonista específico de receptores AT1, inibe o crescimento tumoral em um modelo animal (RIVERA et al., 2001). Outro estudo demonstrou que o bloqueio dos receptores AT1 também promovia o aumento da apoptose e a redução da expressão de fatores de crescimento importantes para diversos processos pró- 
tumorigênicos (ARRIETA et al., 2005). Evidências da expressão gênica do fator de crescimento VEGF (Vascular Endotelial Growth Factor) mediada pelo SRA também foram obtidas em estudos de outros tipos de câncer, como os de mama e ovário (BUYSSACHERT et al., 2009; YIN et al., 2009). Esses dados sugerem que a sinalização mediada pela Ang II seja relevante na angiogênese promovida pelos tumores.

Assim, frente ao exposto acima, uma investigação mais detalhada do papel do SRA em gliomas é justificada. Com esse intuito, uma abordagem interessante seria identificar os genes expressos pela ativação dos receptores AT1 ou AT2 pela Ang II. Essa abordagem possibilitaria uma correlação do padrão de expressão gênica promovida pela ativação desses receptores com suas respectivas funções no tumor.

\subsection{Estudos de genômica funcional em gliomas}

Apesar da existência de numerosos desafios, nos últimos anos houve um notável progresso na caracterização molecular dos gliomas malignos, com o grande auxílio das tecnologias genômicas e de biologia molecular. A análise genômica integrada também tem facilitado a identificação e caracterização de genes adicionais envolvidos na patogênese dos gliomas (HOLLAND, 2010). Atualmente, os estudos das alterações genômicas em tumores cerebrais são utilizados não apenas para a obtenção de indicadores de prognóstico, mas também com o objetivo de se identificar novos alvos terapêuticos. Marie et al. (2007), por exemplo, demonstraram a relação entre a expressão do gene MELK e o grau de malignidade em astrocitomas anaplásicos e GBMs. Scrideli et al. (2008) por sua vez estudaram a expressão de 20 genes relacionados de forma importante com a progressão tumoral do glioblastoma para entender o mecanismo de tumorigênese e identificar novos alvos terapêuticos.

A amplificação dos genes EGFR (Epidermal Growth Factor Receptor) e PDGFR (Platelet-derived Growth Factor Receptor) foi detectada em glioblastomas primários (SUZUKI et al., 2004), sugerindo que esses receptores e suas vias de sinalização são importantes na tumorigênese de gliomas (HUI et al., 2001). De fato, a hiperexpressão de EGFR, incluindo as amplificações desse gene, permite a 
classificação de GBMs em dois subtipos moleculares distintos, com comportamentos e prognósticos diferentes (FIGARELLA-BRANGER, 2008). Outro estudo demonstrou que GBMs pediátricos podem ser classificados baseados em sua associação ou ausência de associação com a via RAS-MAPK ativa (HAQUE, 2007). Mischel et al. (2003) por sua vez indicaram que subtipos de glioblastomas podem ser classificados de acordo com a ativação da via de sinalização de PI3K-AKT-mTOR, descrita como sendo fundamental para a progressão dos glioblastomas (LINO et al., 2011). Também foi demonstrado que a ativação dos componentes dessa via é mais frequente em glioblastoma multiforme do que em tumores de menor grau (CHAKRAVARTI, 2004). Em outro estudo, Rickman et al. (2001) compararam o perfil molecular de gliomas de baixo e alto grau. Foi encontrado que muitos dos genes hiperexpressos em tumores de grau IV codificam proteínas envolvidas no reparo do DNA, replicação e manutenção de proteínas, reguladores da transcrição e tradução, ciclo celular, moléculas associadas à matriz extracelular e adesão celular, além de proteínas participantes da organização do citoesqueleto.

A genômica funcional permite esclarecer quais genes são regulados pela ação de um agonista em seu receptor, fornecendo indicativos do programa transcricional induzido nesse contexto. Nesse sentido, a identificação dos genes expressos pela ativação específica dos receptores AT1 ou AT2 pode oferecer indícios sobre a transdução de sinal induzida pela Ang II em seus receptores. Além disso, a posterior classificação desses genes em suas respectivas funções biológicas fornece indícios para a identificação do papel de cada receptor na progressão de glioblastomas. Também, a partir da aquisição do transcriptoma diferencial gerado, pode-se inferir redes de interação entre os genes identificados (redes de interação transcricional). Mais ainda, é possível colocar essa informação em tela com redes de iteração proteína-proteína, gerando interatomas. Esses interatomas permitem a identificação de proteínas importantes para a modelagem da rede associada ao fenótipo observado. Com essa perspectiva, neste projeto foram estudados os perfis de expressão gênica decorrentes da ativação in vitro dos receptores AT1 ou AT2 pela Ang II, a fim de se avaliar o mecanismo de ação da Ang II em um modelo de glioma. 


\section{OBJETIVOS}

\subsection{Objetivo geral}

O objetivo geral deste projeto foi o estudo do transcriptoma regulado pela ação da Ang II em seus receptores AT1 e AT2, na linhagem celular C6.

\subsection{Objetivos específicos}

- Identificar, por análise de expressão gênica em larga escala (utilizando DNA microarrays), os genes cuja expressão é alterada pela ação da Ang II em seus receptores na linhagem celular C6;

- determinar as funções biológicas hiper-representadas a partir dos genes diferencialmente expressos encontrados, por meio das ferramentas de bioinformática GO (Gene Ontology), KEGG (Kyoto Encyclopaedia of Genes and Genomes) e FunNet;

- identificar sobreposições entre os resultados obtidos nas diferentes comparações realizadas, utilizando diagramas de Venn;

- construir interatomas a partir das proteínas codificadas pelos genes diferencialmente expressos obtidos em cada comparação, utilizando a ferramenta de bioinformática Cytoscape e seu plugin Bisogenet;

- validar, por PCR em tempo real (qPCR), alguns genes diferencialmente expressos para comparar os resultados encontrados por DNA microarrays e qPCR. 


\section{MATERIAIS E MÉTODOS}

\subsection{Culturas celulares}

Células $\mathrm{C} 6$ foram cultivadas em placas de Petri de $75 \mathrm{~mm}$ de diâmetro para culturas celulares (TPP, St. Louis, MO, USA) e meio DMEM (Dulbecco's modified Eagle's medium) suplementado com antibióticos (penicilina/estreptomicina) e 10\% de soro fetal bovino (Cultilab, Brasil). Após a confluência das culturas, essas células foram pré-tratadas (30 minutos) com os antagonistas do receptor AT1 (Losartan: 10${ }^{5} \mathrm{M}$ - Sigma-Aldrich, St. Louis, MO, USA) e AT2 (PD123319: $10^{-5} \mathrm{M}$ - Sigma-Aldrich) e posteriormente tratadas com $10^{-7} \mathrm{M}$ de Angiotensina II (Sigma-Aldrich), conforme $\mathrm{O}$ seguinte esquema de tratamento: Grupo 1 - controle; Grupo 2 - células tratadas com Ang II; Grupo 3 - células tratadas com Losartan e Ang II e Grupo 4 - células tratadas com PD123319 e Ang II. Decorridos os intervalos de 3 e 6 horas, o RNA dessas células foi extraído. Esses intervalos de tempo foram escolhidos devido aos achados de Arrieta et al. (2005): utilizando células C6 esses autores observaram um aumento da proliferação celular e da apoptose após 6 horas de tratamento com Ang II e Losartan, respectivamente. Portanto, provavelmente alterações importantes no perfil de expressão gênica global também ocorram ao longo desse período em resposta à administração da Ang II e dos antagonistas de AT1 e AT2.

\subsection{Extração do RNA total}

O RNA foi extraído com o kit RNeasy ${ }^{\circledR}$ Mini (Qiagen, Germantown, MD, USA) seguindo as instruções do fabricante. Para avaliar a integridade do RNA extraído, todas as amostras foram analisadas com o auxílio do Bioanalyzer 2100 (Agilent Technologies, Santa Clara, CA, USA). A análise realizada pela plataforma Bioanalyzer informa de forma automatizada parâmetros de integridade do RNA por meio da variável RIN (RNA Integrity Number). O RIN varia de zero a dez, indicando respectivamente de zero a cem por cento de integridade do RNA (SCHROEDER et al., 2006). Foram utilizadas somente amostras com $R I N \geq 8$. 


\subsection{Microarray de oligonucleotídeos de DNA}

Os experimentos para análise de expressão gênica foram realizados na plataforma da Agilent Technologies, seguindo os protocolos fornecidos pelo fabricante. Foram utilizadas lâminas de DNA microarrays com oligonucleotídeos de 60 bases, individualmente pré-validados, contendo 44.000 transcritos do genoma de rato (Agilent whole rat genome $4 X 44 K$ v3 oligonucleotide microarrays, G2519F028282).

\subsubsection{Amplificação e marcação fluorescente do RNA}

Kits Agilent Quick Amp Labeling foram utilizados na geração do cRNA (RNA complementar) para a etapa de hibridização. O protocolo consiste da transcrição reversa de uma alíquota de $700 \mathrm{ng}$ de RNA total em cDNA. Depois, o cDNA sintetizado é transcrito in vitro em cRNA e marcado com o corante fluorescente Cy3. O cRNA marcado é então purificado utilizando colunas RNeasy Mini (Qiagen). Por fim, a qualidade de cada amostra de cRNA é confirmada a partir do rendimento total obtido e da atividade específica da Сy3, calculados com base em medidas espectrofotométricas obtidas no Nanovue (GE Healthcare, WI, USA). Foram consideradas qualificadas as amostras que apresentaram rendimento superior a $1.65 \mu \mathrm{g}$ e atividade específica maior que 9 pmol de Cy3 por $\mu \mathrm{g}$ de RNA.

\subsubsection{Hibridização das lâminas de DNA microarray e aquisição dos dados}

As lâminas de DNA microarray foram incubadas a $65^{\circ} \mathrm{C}$ por 17 horas em uma câmara de hibridização e submetidas às etapas de lavagem de acordo com o protocolo da Agilent (Versão 5.7, Março de 2008). Após a hibridização das lâminas, as imagens foram capturadas pelo leitor Agilent Bundle (Agilent Technologies G2505B DNA microarray scanner) e extraídas pelo software Feature Extraction versão 9.5.3 (Agilent Technologies). A qualidade das lâminas foi analisada pelo relatório de controle de qualidade gerado pelo software. Esse relatório apresenta parâmetros tais como reprodutibilidade, distribuição gaussiana dos sinais de fluorescência encontrados, comportamento similar do sinal processado e do 
background nas diferentes linhas e colunas do microarray, distribuição uniforme do background e obtenção de uma curva de comportamento linear $\left(R^{2}=0.99\right)$ utilizando como pontos os sinais de fluorescência obtidos de diferentes RNAs spike-in.

\subsubsection{Processamento e análise dos resultados de DNA microarray obtidos}

O ambiente estatístico R (http://www.r-project.org) foi usado para filtrar e analisar os dados. O parâmetro considerado para as análises de bioinformática foi o sinal processado (gProcessedSignal) gerado pelo software Feature Expression (v9.5.3). As médias das intensidades de sinal das sondas de cada gene foram obtidas, os genes com valores ausentes foram removidos e em seguida, foi calculado o logaritmo na base 2 (log2) dos valores encontrados. Os dados foram então normalizados utilizando o método de Löwess (YANG et al., 2002) para corrigir possíveis vieses sistemáticos decorrentes da intensidade do sinal obtido entre os microarrays. Para determinar diferenças estatisticamente significativas na expressão dos transcritos avaliados, foi utilizado o teste estatístico t de Student pareado com $\mathrm{p}<0.05$. As seguintes comparações foram realizadas: I) Ang II $\times$ Controle (3 h); II) Ang II x Controle (6 h); III) Ang II + Los x Ang II (3 h); IV) Ang II + Los x Ang II (6 h); V) Ang II + PD x Ang II (3 h); VI) Ang II + PD x Ang II (6 h).

\subsection{Análises de Bioinformática}

Os procedimentos de bioinformática utilizados para a obtenção dos insights biológicos a partir dos genes diferencialmente expressos encontram-se na Figura 1. Para procurar categorias biológicas hiper-representadas no conjunto de genes diferencialmente expressos, os genes diferencialmente expressos obtidos pelos resultados de DNA microarray foram inseridos nos bancos de dados GO e KEGG utilizando a ferramenta FunNet (http://www.funnet.ws). Para identificar genes diferencialmente expressos comuns entre as comparações realizadas nos intervalos 3 e 6 horas, diagramas de Venn foram construídos utilizando o software Gene List Venn Diagrams (PIROOZNIA et al., 2007). Por fim, redes de interação entre os genes diferencialmente expressos foram construídas utilizando o software Cytoscape e seu plug-in Bisogenet (MARTIN et al., 2010). 
Figura 1- Pipeline de bioinformática utilizados para a obtenção dos insights biológicos a partir dos genes diferencialmente expressos.

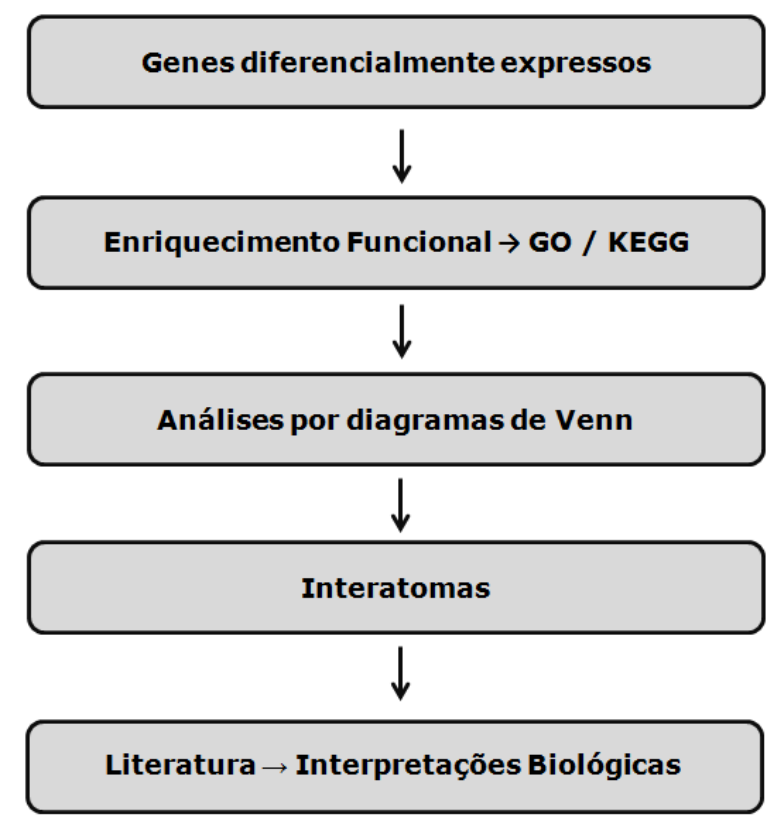

\subsection{PCR quantitativo em tempo real (qPCR)}

A qPCR foi realizada utilizando os kits SuperScript ${ }^{\circledR}$ III Reverse Transcriptase (Life Technologies, La Jolla, CA, USA) e QuantiFast SYBR Green PCR Kit (Qiagen). A 2,0 $\mu$ de cDNA diluído $10 \times$ foram adicionados $1 \mu \mathrm{l}$ de primer sense, 1,0 $\mu \mathrm{l}$ de primer anti-sense (10 pmol cada), 12,5 $\mu$ de Master Mix 2X e água destilada e deionizada suficiente para completar $25 \mu \mathrm{l}$ de reação. As amostras foram incubadas à $95^{\circ} \mathrm{C}$ por 5 minutos, e submetidas a 40 ciclos de $95^{\circ} \mathrm{C}$ por $30 \mathrm{~s}$ e $60^{\circ} \mathrm{C}$ por $30 \mathrm{~s}$. Os primers foram desenhados a partir do software Primer 3 ou selecionados de artigos científicos. Os controles de especificidade das reações foram a presença de apenas um pico de fluorescência na curva de dissociação e a ausência de amplificação nas reações em que o cDNA estava ausente. A quantificação da expressão gênica foi realizada por meio de quantificação relativa a partir de curva padrão. Os dados foram normalizados pela expressão gênica de GAPDH. A significância estatística foi determinada pelo teste ANOVA seguido de teste post hoc Tukey, com $\mathrm{p}<0.05$. 


\section{RESULTADOS}

\subsection{Padronizações das culturas celulares e do modelo utilizado}

Culturas celulares foram realizadas com o intuito de se padronizar 0 cultivo das células C6. Essas células foram gentilmente cedidas pela Prof ${ }^{a}$ Sueli K. Nagahashi Marie da FMUSP. Com essas culturas, foram realizados os tratamentos com Ang II, Losartan e PD1223319, conforme descrito na Metodologia deste projeto. O RNA dessas culturas foi extraído nos intervalos de 3 e 6 horas e sua integridade analisada com a plataforma Bioanalyzer. Na Figura 2 , há um exemplo da análise gerada pelo Bioanalyzer, com o valor RIN de cada amostra.

Figura 2 - Análise da integridade do RNA extraído de células C6.

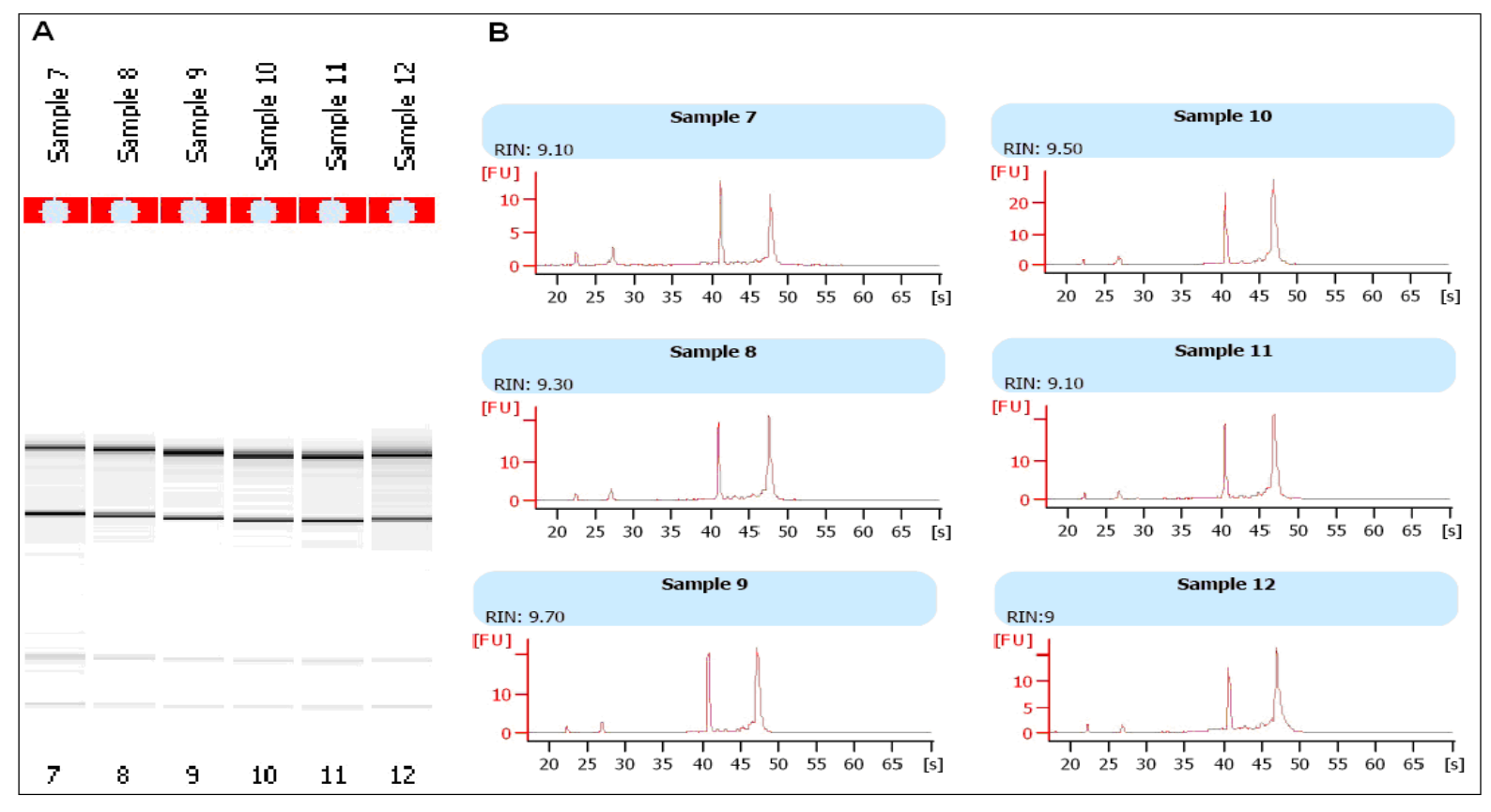

Células C6 foram tratadas com Ang II, Losartan e PD123319 por 3 e 6 horas e seu RNA foi extraído. A seguir, esse RNA foi quantificado e sua integridade analisada. (A) Imagem virtual ("gel-like") gerada pelo Bioanalyzer indicando a presença das bandas $18 \mathrm{~S}$ e $28 \mathrm{~S}$ e a ausência de um "smear", o qual indicaria a degradação do RNA. (B) Eletroferograma do RNA analisado de cada amostra, indicando os picos correspondentes aos rRNAs $18 \mathrm{~S}$ e $28 \mathrm{~S}$. 
Foram realizadas reações de qPCR para avaliar a expressão de alguns genes antes de serem iniciados os experimentos de DNA microarray. A escolha desses genes foi motivada pela busca na literatura de genes relevantes em tumores, expressos em células C6 e que foram demonstrados em outros modelos experimentais serem induzidos pela Ang II. Essa abordagem foi necessária para confirmar que as células C6 apresentam resposta transcricional a Ang II e seus antagonistas nos intervalos de tempo estudados. Foram selecionados os genes Ccl2 (chemokine C-C motif ligand 2) e Mmp9 (matrix metallopeptidase 9), além do gene GAPDH como controle endógeno. Os primers para esses genes foram selecionados (Quadro 2) de artigos da literatura (CHIPITSYNA, 2007; LI; ZHUO, 2008; YEH, 2009). O gene Ccl2 é responsável pelo recrutamento de macrófagos para o ambiente tumoral e o gene Mmp9 relacionado à degradação de matriz extracelular relevante para a invasão celular e angiogênese.

\section{Quadro 2 - Primers utilizados nas reações de qPCR dos genes Ccl2 e Mmp9}

\begin{tabular}{|c|c|c|}
\hline Gene & Primer forward & Primer reverse \\
\hline CCL2 & 5'-CCTGTTGTTCACAGTTGCTGCC-3' & 5'-TCTACAGAAGTGCTTGAGGTGGTTG-3' \\
\hline MMP9 & 5'-CCCCACTTACTTTGGAAACGC-3' & 5'-ACCCACGACGATACAGATGCTG-3' \\
\hline GAPDH & 5'-ACCACAGTCCATGCCATCAC-3' & 5'-TCCACCACCCTGTTGCTGTA-3' \\
\hline
\end{tabular}

Os resultados de qPCR (Figura 3) revelaram que ambos os genes analisados possuem expressão significativamente aumentada às 3 horas de tratamento no grupo Ang II em relação ao controle. Ademais, foi observado que quando as células C6 foram tratadas previamente (30 minutos antes) com o antagonista Losartan, o aumento da expressão de Mmp9 e Ccl2 foi inibido. Por outro lado, o antagonista PD123319 somente inibiu a expressão de Ccl2. Isso sugere que ambos os receptores da Ang II (AT1 e AT2) modulam a expressão de Ccl2 em células C6, enquanto que a expressão de Mmp9 é dependente somente do receptor AT1. 
Figura 3 - A expressão de Mmp9 e Ccl2 é regulada pela Ang II em gliomas.
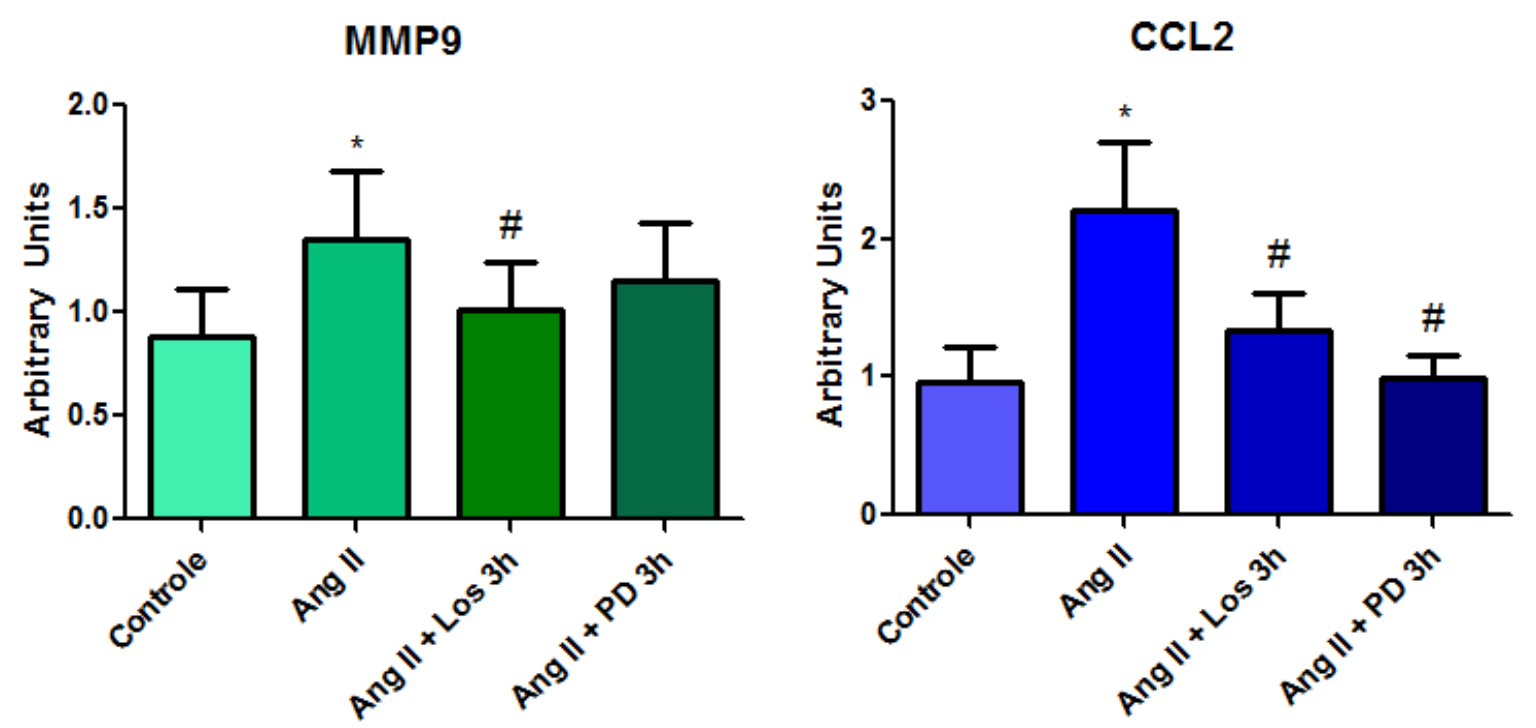

Células C6 foram tratadas com Ang II, Losartan e PD123319 por 3h e o seu RNA foi extraído. Reações de qPCR foram realizadas para os genes Ccl2 e Mmp9, e suas expressões gênicas foram normalizadas pela expressão do gene GAPDH. Os resultados estão representados como a média do fold relativo ao controle \pm erro padrão $(n=4)$. A significância estatística foi determinada por ANOVA de uma via de medidas repetidas, seguido de pós-teste Tukey com p $\leq$ 0.05. * em relação ao Controle; \# em relação a Ang II.

\subsection{Análise da qualidade da hibridização dos DNA microarrays}

As lâminas hibridizadas foram lidas no leitor Agilent Bundle sendo gerada uma imagem de alta resolução para cada amostra. O sinal de fluorescência emitido em cada ponto de hibridização foi posteriormente quantificado e convertido em dados representativos da quantidade relativa de cRNA hibridizado, utilizando o programa Feature Extraction. Esse programa também gera um relatório sobre 0 controle de qualidade das lâminas, o qual avalia diversos parâmetros como localização dos cantos do array, distribuição espacial dos sinais outliers, histograma dos sinais plotados, reprodutibilidade das sondas em replicata e estatística dos RNAs spike-in. Após a confirmação de que todos esses parâmetros estavam de acordo com os critérios de aceitação, os dados brutos foram utilizados para as fases subsequentes de análise. 


\subsection{Análise transcriptômica da transdução de sinal promovida pela Ang II}

A comparação estatística entre os grupos Ang II e Controle permitiu identificar quais foram os genes ativados a partir da ativação dos receptores da Ang II nos intervalos de 3 e 6 horas de tratamento. Após a análise estatística e remoção dos transcritos que não apresentam Entrez GenelD, parâmetro de identificação utilizado na categorização dos genes por meio de GO e KEGG, foram obtidos respectivamente 673 genes (358 hiperexpressos e 315 hipoexpressos) e 1139 genes (547 hiperexpressos e 592 hipoexpressos) nos intervalos de 3 e 6 horas. Os genes mais relevantes e suas respectivas funções biológicas estão contidos nos quadros suplementares S1 a S4 no Apêndice A.

\subsubsection{Intervalo de 3 horas de tratamento com Ang II}

Os processos biológicos hiper-representados em GO após o intervalo de 3 horas de tratamento com Ang II estão sumarizados na Figura 4. As funções com genes hiperexpressos mais relevantes foram: regulação da transcrição, ciclo e divisão celular, transporte de proteínas, transdução intracelular do sinal, transdução de sinal mediada por GTPase, dobramento de proteínas, ubiquitinação de proteínas e organização do citoesqueleto de actina. Por outro lado, o tratamento com Ang II por 3 horas reduziu a expressão de genes relacionados à regulação da transcrição, resposta a substância orgânica, transporte de íons, desenvolvimento do cérebro, transporte de proteínas, regulação da proliferação celular e da apoptose e resposta à hipóxia. 


\section{Figura 4 - Processos biológicos categorizados segundo GO após 3 horas de tratamento com Ang II.}

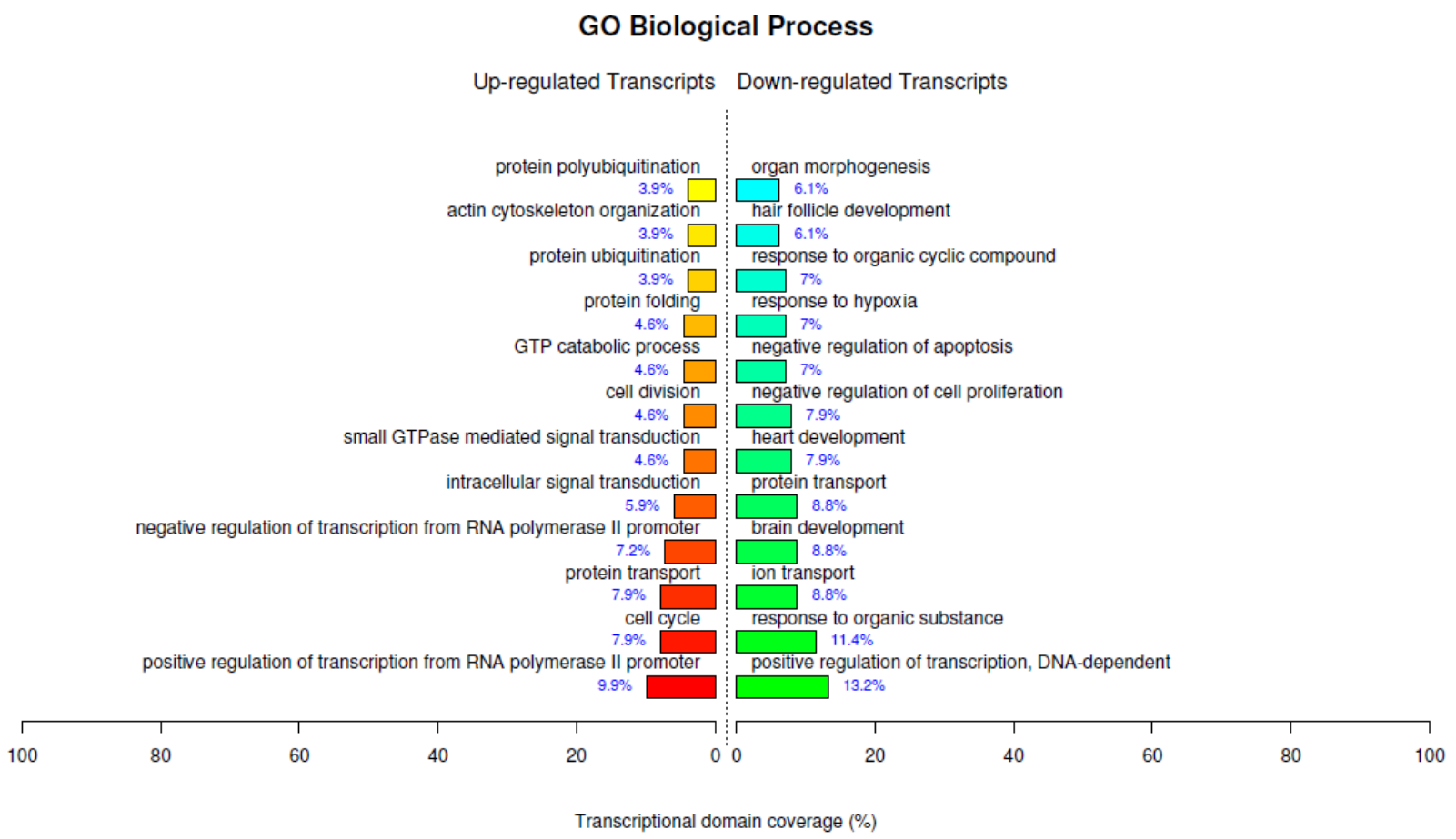

Os temas com genes hiper e hipoexpressos estão representados em vermelho e verde, respectivamente.

Utilizando a base de dados KEGG foi também possível identificar vias de sinalização e funções biológicas hiper-representadas (Figura 5). Observamos que após 3 horas de tratamento com Ang II houve a hiperexpressão de genes pertencentes às vias de sinalização das MAP cinases, quimiocinas, ErbB, neurotrofinas e insulina, além de outras funções biológicas como a regulação do citoesqueleto de actina, junções aderentes, proteólise mediada pela ubiquitina, leucemia mielóide crônica, ciclo celular e glioma. Por outro lado, a Ang II no intervalo de 3 horas diminui a expressão de genes pertencentes às vias de sinalização de TGF- $\beta$, PPAR, mTOR e Notch, além de genes pertencentes a funções de processamento de proteínas no retículo endoplasmático, interação matriz extracelular-receptor, biossíntese de $\mathrm{N}$-glicanos e reabsorção de sódio regulada pela aldosterona. 


\section{Figura 5 - Temas hiper-representados em KEGG após 3 horas de tratamento com Ang II.}

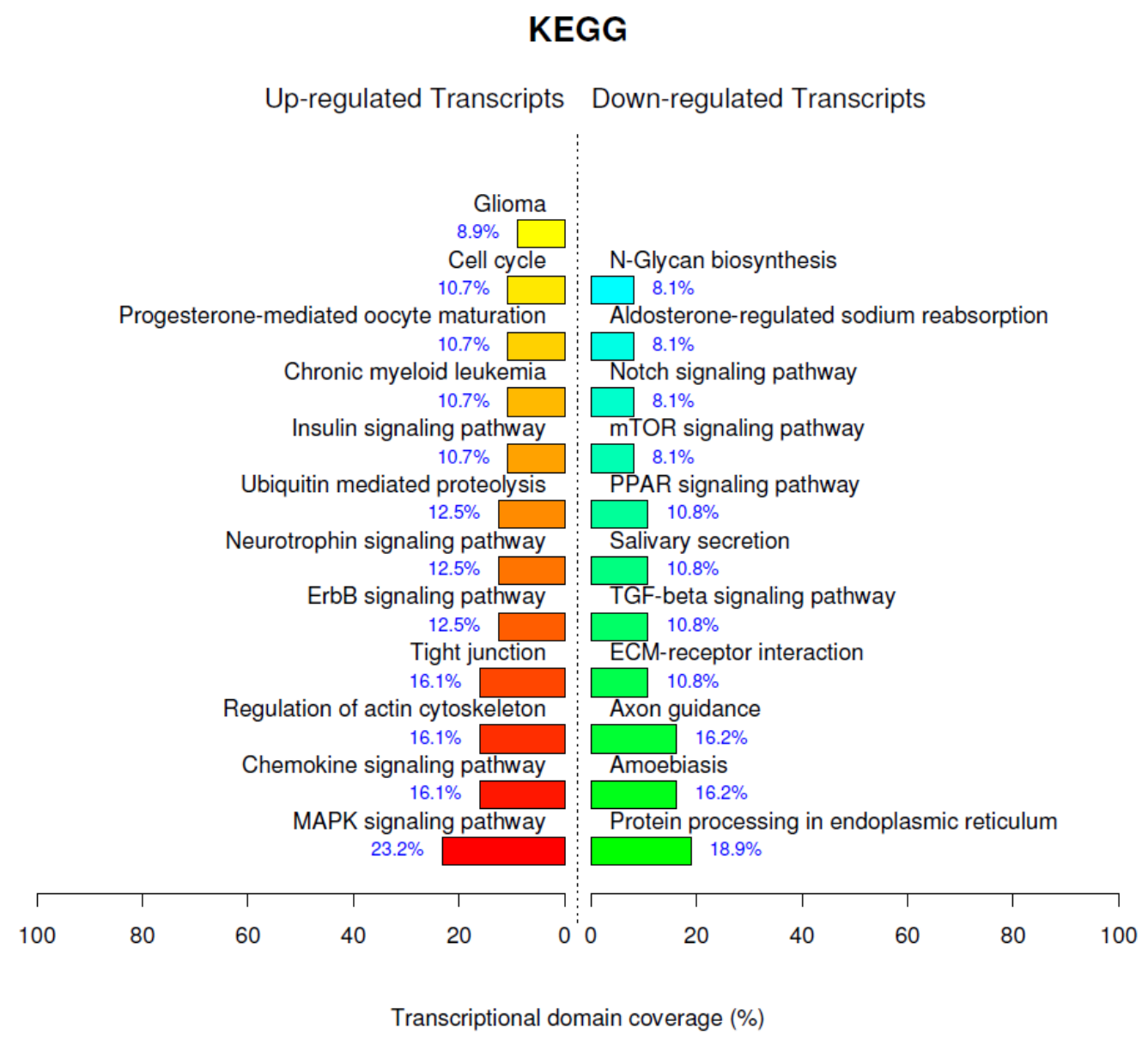

Os temas com genes hiper ou hipoexpressos estão representados em vermelho e verde, respectivamente.

\subsubsection{Intervalo de 6 horas de tratamento com Angiotensina II}

Os principais processos biológicos hiper-representados em GO após o tratamento com Ang II por 6 horas estão sumarizados na Figura 6. Os processos que apresentaram genes hiperexpressos pela ação da Ang II foram a fosforilação de proteínas, apoptose, regulação negativa da proliferação celular, ciclo e divisão celular, organização do citoesqueleto de actina, reparo e replicação do DNA, desenvolvimento do sistema nervoso e processo catabólico dependente da via ubiquitina-proteossomal e promotor da anáfase. Por outro lado, nesse intervalo de tempo a Ang II causou a hipoexpressão de genes pertencentes a apoptose, transporte de proteínas, transdução intracelular de sinal, resposta ao estresse 
oxidativo, organização da membrana celular, ubiquitinação de proteínas, regulação da migração celular e resposta à glicose.

Os principais temas hiper-representados em KEGG após a ativação das células C6 pela Ang II estão sumarizados na Figura 7. Os temas que apresentaram genes hiperexpressos foram: ciclo celular, vias em câncer, transporte de RNA, sinalização das MAPK, adesão focal, vias de sinalização da insulina e de ErbB, spliceossomo, proteólise mediada pela ubiquitina e processamento de proteínas no retículo endoplasmático. Por outro lado, a Ang II reduziu a expressão de genes pertencentes à doença de Parkinson, absorção mineral, via de sensibilidade ao DNA citossólico, biossíntese de pantotenoato e CoA, exportação de proteínas e metabolismo da riboflavina.

Figura 6 - Processos biológicos categorizados segundo GO após 6 horas de tratamento com Angiotensina II.

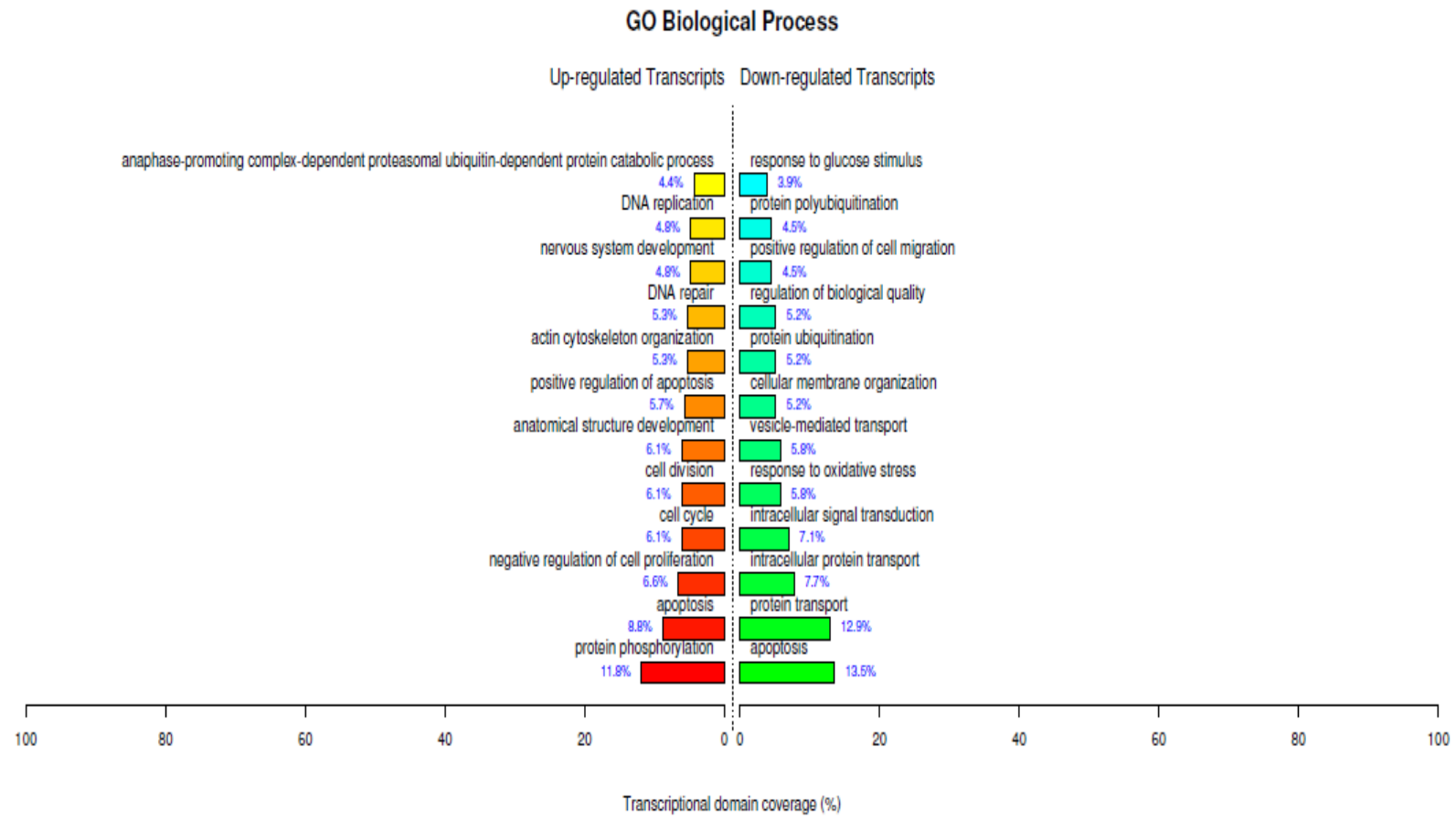

Os temas com genes hiper e hipoexpressos estão representados em vermelho e verde, respectivamente. 


\section{Figura 7 - Temas hiper-representados em KEGG após 6 horas de tratamento com Ang II.}

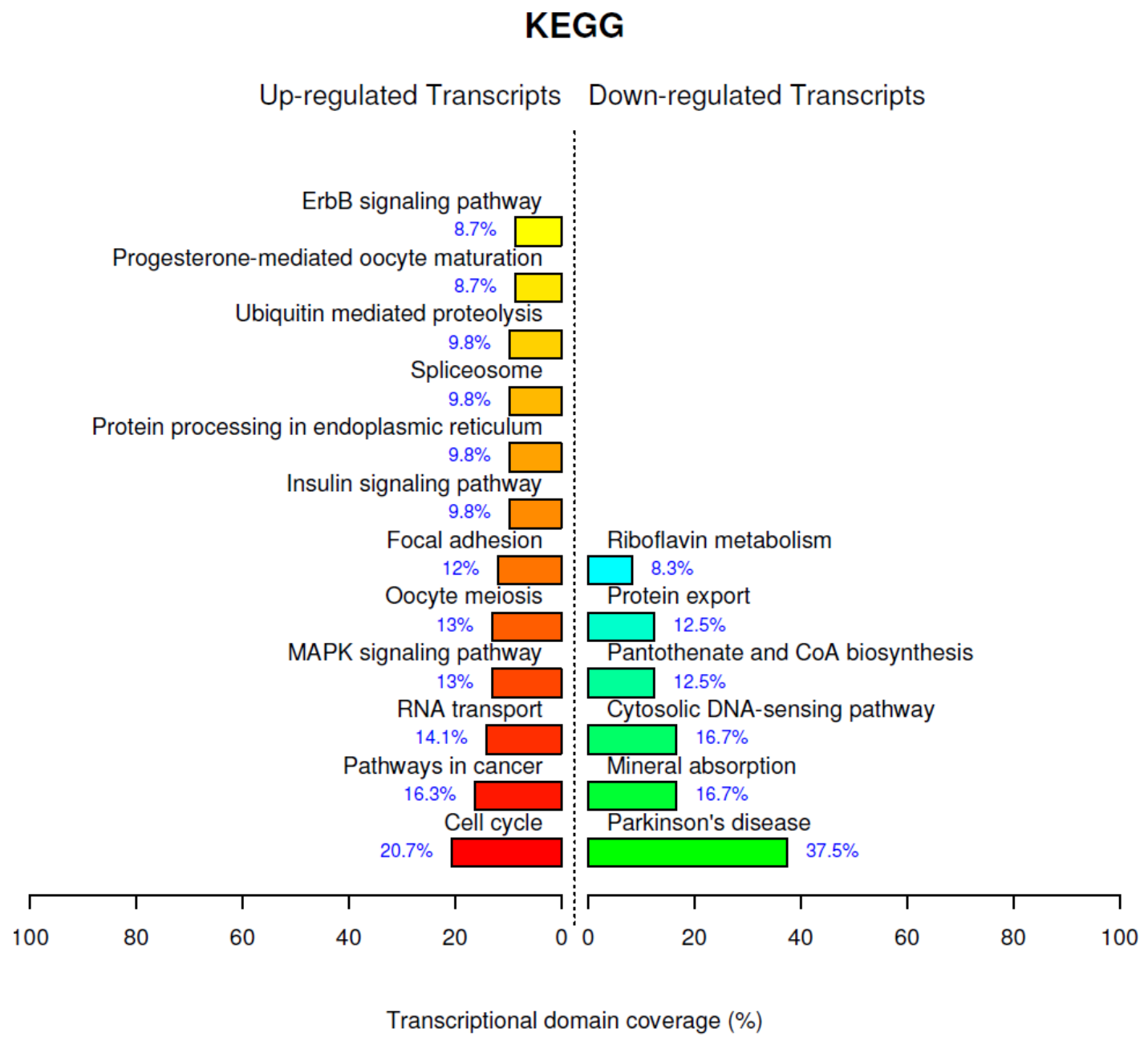

Os temas com genes hiper e hipoexpressos estão representados em vermelho e verde, respectivamente. 


\subsection{Análise transcriptômica da transdução de sinal ativada pelo receptor AT1}

A comparação entre os grupos Ang II + Los e Ang II permitiu identificar os genes regulados pelo receptor AT1 nos intervalos de 3 e 6 horas. Após a análise estatística e a remoção dos transcritos que não apresentam Entrez Gene $I D$, foram obtidos 248 genes diferencialmente expressos (100 hipoexpressos e 148 hiperexpressos) e 441 genes diferencialmente expressos (186 hiperexpressos e 255 hipoexpressos) respectivamente nos intervalos de 3 e 6 horas. Os genes mais relevantes e suas respectivas funções biológicas estão contidos nos quadros suplementares S5 a S8 no Apêndice A.

\subsubsection{Intervalo de 3 horas de tratamento com Ang II e Losartan}

Os principais processos biológicos hiper-representados em GO nesse intervalo estão sumarizados na Figura 8. Os principais processos biológicos que apresentaram genes hipoexpressos pela ação do Losartan foram regulação da transcrição, ciclo celular, mitose, divisão celular, reparo de DNA, resposta ao dano do DNA, migração celular, regulação negativa da transdução de sinal, oligomerização de proteínas e processo metabólico de carboidratos. Os genes hiperexpressos pela ação do Losartan, por sua vez, apresentaram como funções hiper-representadas em GO: transporte de proteínas, regulação da apoptose, resposta inflamatória, regulação da migração celular, regulação da transcrição e cascata de proteína cinase intracelular.

Os temas biológicos hiper-representados em KEGG estão sumarizados na Figura 9. Os principais temas que apresentaram genes hipo-regulados foram: ciclo celular, via de sinalização de P53, metabolismo de aminoácidos e nucleotídeos, reabsorção da água regulada pela vasopressina e replicação de DNA. Os genes hiper-regulados pela ação do Losartan, por sua vez, apresentaram como funções hiper-representadas em KEGG: vias metabólicas, lisossomos, leucemia mielóide aguda e biossíntese hormônios esteroides e N-glicanos. 


\section{Figura 8 - Processos biológicos categorizados segundo GO e mediados pelo receptor AT1 no intervalo de 3 horas.}

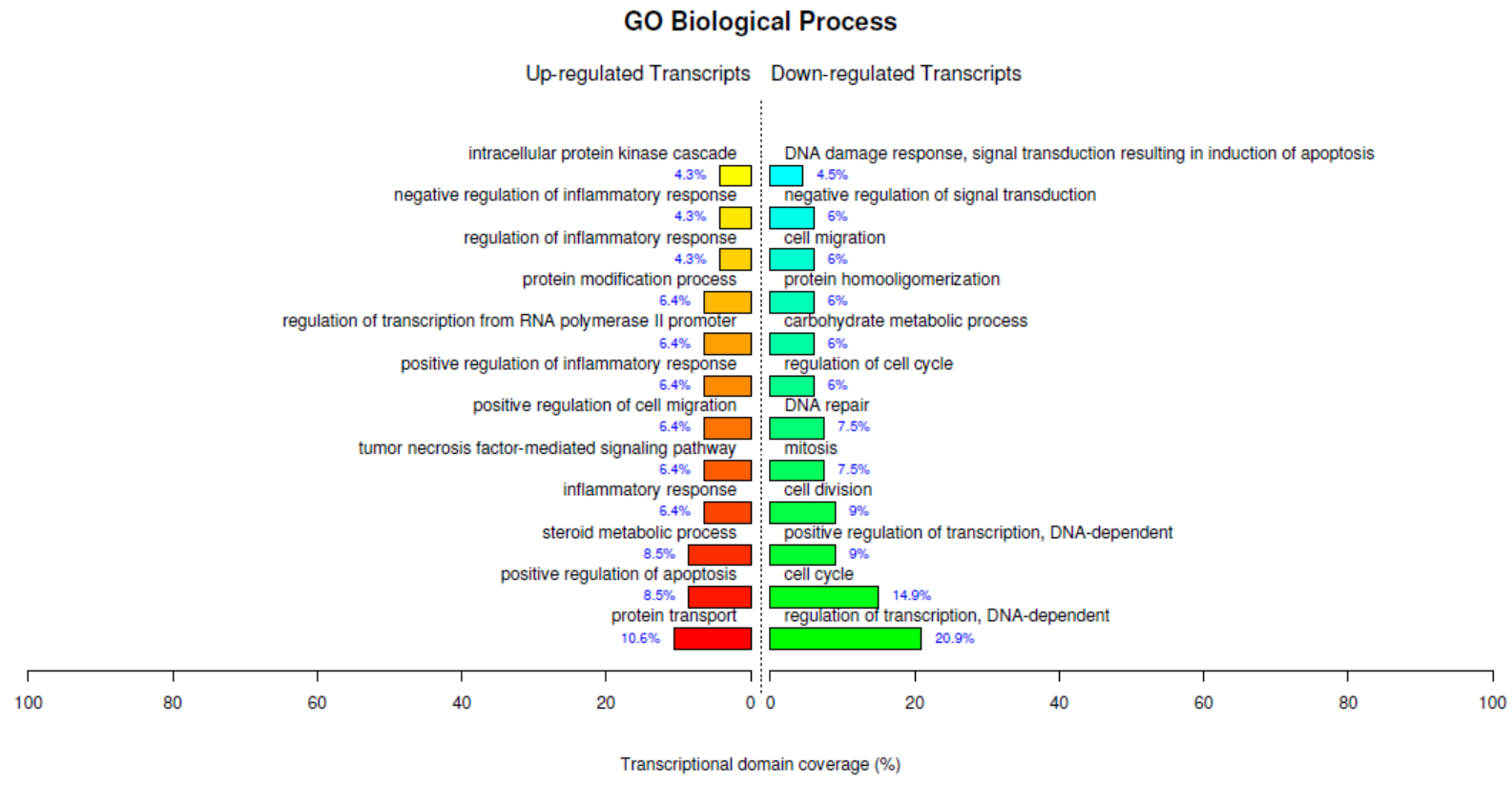

Os temas com genes hiper e hipoexpressos estão representados em vermelho e verde, respectivamente.

Figura 9 - Temas hiper-representados em KEGG e modulados via receptor AT1 no intervalo de 3 horas.

\section{KEGG}

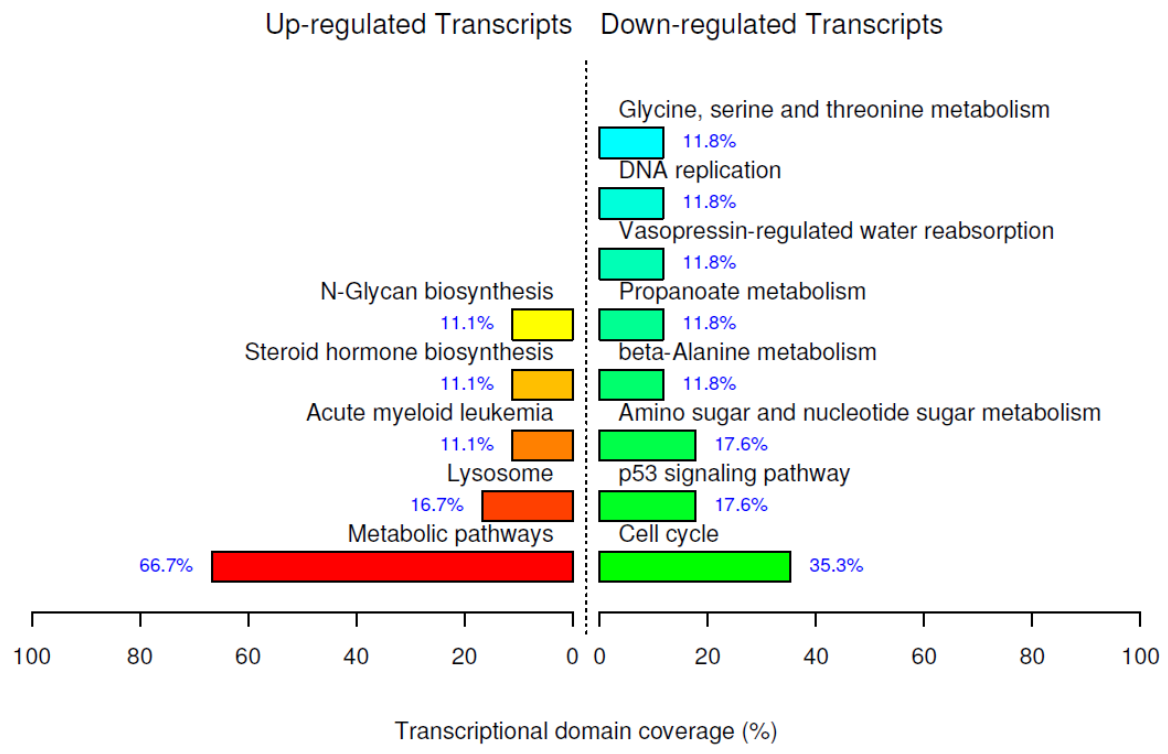

Os temas com genes hiper e hipoexpressos estão representados em vermelho e verde, respectivamente. 


\subsubsection{Intervalo de 6 horas de tratamento com Ang II e Losartan}

Os principais processos biológicos hiper-representados em GO a partir da comparação Ang II + Losartan x Ang II no intervalo de 6 horas estão sumarizados na Figura 10. Os principais processos biológicos que apresentaram genes hipoexpressos pela ação do Losartan foram regulação da transcrição, regulação do processo biossintético celular, regulação positiva da expressão gênica, transdução de sinal, diferenciação celular, resposta à substância orgânica e regulação positiva da proliferação celular. Os genes hiper-regulados pela ação do Losartan, por sua vez, apresentaram como principais funções: ubiquitinação e processo catabólico de proteínas, ciclo celular, reparam de DNA, regulação do crescimento celular, divisão celular, regulação da tradução e resposta a estímulo de hormônio peptídico.

As principais vias metabólicas e de sinalização hiper-representadas em KEGG estão sumarizadas na Figura 11. As principais funções que apresentaram genes hipo-regulados foram adesão focal, regulação do citoesqueleto de actina, via de sinalização de quimiocinas, lisossomos, guidance axonal, via de sinalização de PPAR, junções aderentes, biossíntese de tRNA aminoacilado, biossíntese de ácidos graxos insaturados e absorção e digestão de vitaminas. Os genes hiperexpressos por sua vez apresentaram como funções principais: transporte de RNA, ciclo celular, peroxissomos, metabolismo de pirimidinas, via de sinalização de p53, proteassomo, metabolismo de riboflavinas, recombinação homóloga e RNA polimerase. 


\section{Figura 10 - Processos biológicos categorizados segundo GO e mediados pelo receptor AT1 no intervalo de 6 horas.}

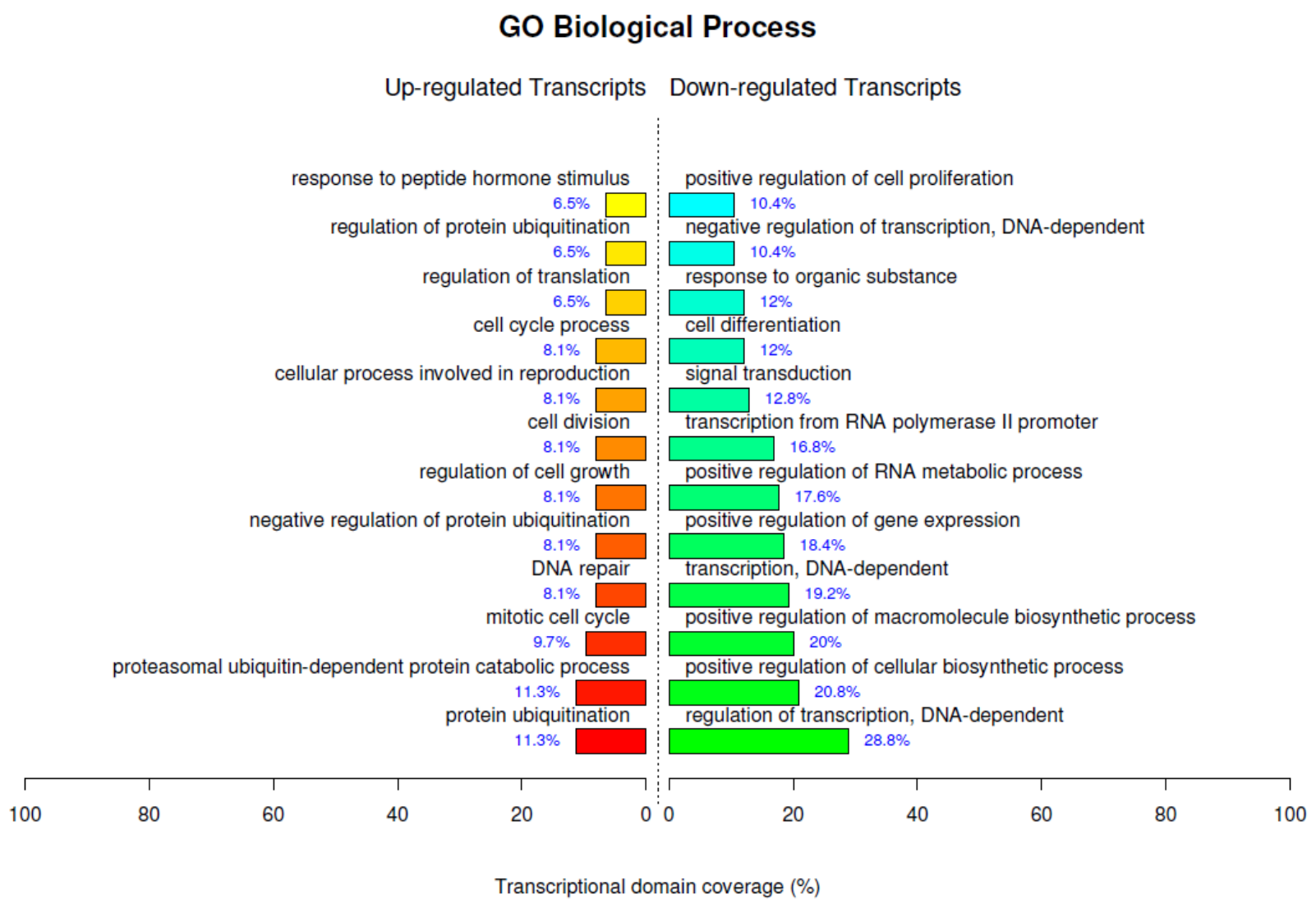

Os temas com genes hiper e hipoexpressos estão representados em vermelho e verde, respectivamente. 
Figura 11 - Temas hiper-representados em KEGG e modulados via receptor AT1 no intervalo de 6 horas.

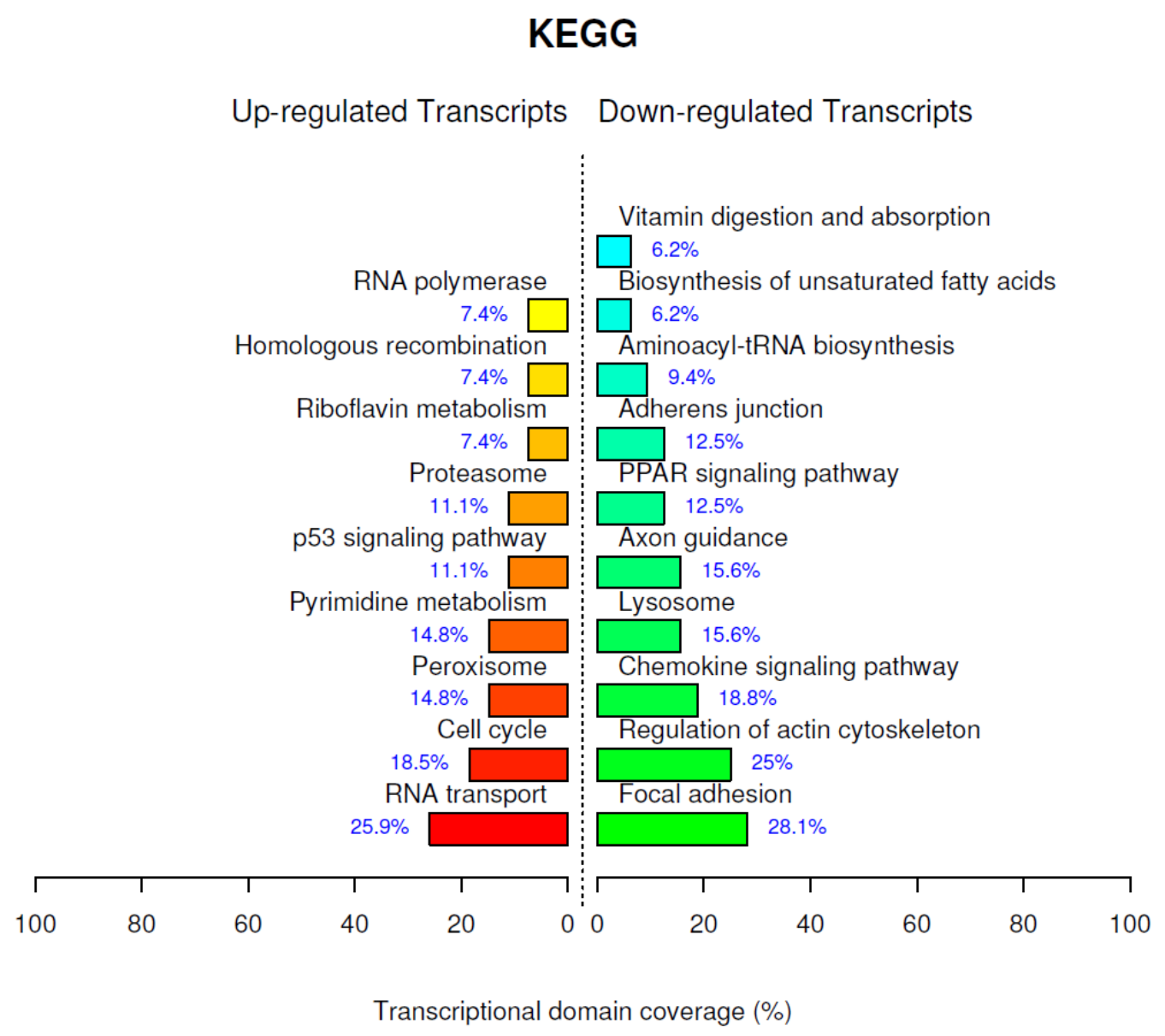

Os temas com genes hiper e hipoexpressos estão representados em vermelho e verde, respectivamente.

\subsection{Análise transcriptômica da transdução de sinal ativada pelo receptor AT2}

A comparação Ang II + PD123319 x Ang II permitiu identificar os genes regulados pelo receptor AT2 nos intervalos de 3 e 6 horas. Após a análise estatística e a remoção dos transcritos que não apresentam Entrez Gene ID, foram obtidos 334 (116 hiper e 218 hipoexpressos) e 972 genes diferencialmente expressos (386 hiper e 541 hipoexpressos) respectivamente nos intervalos de 3 e 6 horas. Os genes mais relevantes e suas respectivas funções biológicas estão contidos nos quadros suplementares S9 a S12 no Apêndice A. 


\subsubsection{Intervalo de 3 horas de tratamento com Ang II e PD123319}

Os principais processos biológicos hiper-representados em GO nesse intervalo estão sumarizados na Figura 12. As principais funções que apresentaram genes hipoexpressos pela ação do PD123319 foram: regulação da transcrição, diferenciação celular, regulação negativa da apoptose, regulação da proliferação celular, adesão celular, via de sinalização de Wnt, regulação da transdução de sinal e envelhecimento. Os genes hiperexpressos pela ação do PD123319 por sua vez apresentaram como funções diferenciação celular, angiogênese e desenvolvimento vascular, resposta ao estímulo de hormônio peptídico, processos biológicos relacionados a desenvolvimento, via de sinalização de Wnt e processo metabólico de nucleotídeos.

Os dados da análise de KEGG para essa comparação estão sumarizados na Figura 13. Os temas mais relevantes com genes hipoexpressos pela ação do antagonista foram vias em câncer, via de sinalização de MAPK, regulação do citoesqueleto de actina, via de sinalização de ErbB, adesão focal e funções relacionadas ao sistema imune. Os genes hiperexpressos por sua vez apresentaram como funções relevantes o metabolismo de purinas, biossíntese de hormônios esteroides, metabolismo de retinol, metabolismo de drogas e biossíntese de $\mathrm{N}$ glicanos. 


\section{Figura 12 - Processos biológicos categorizados segundo GO e mediados pelo receptor AT2 no intervalo de 3 horas.}

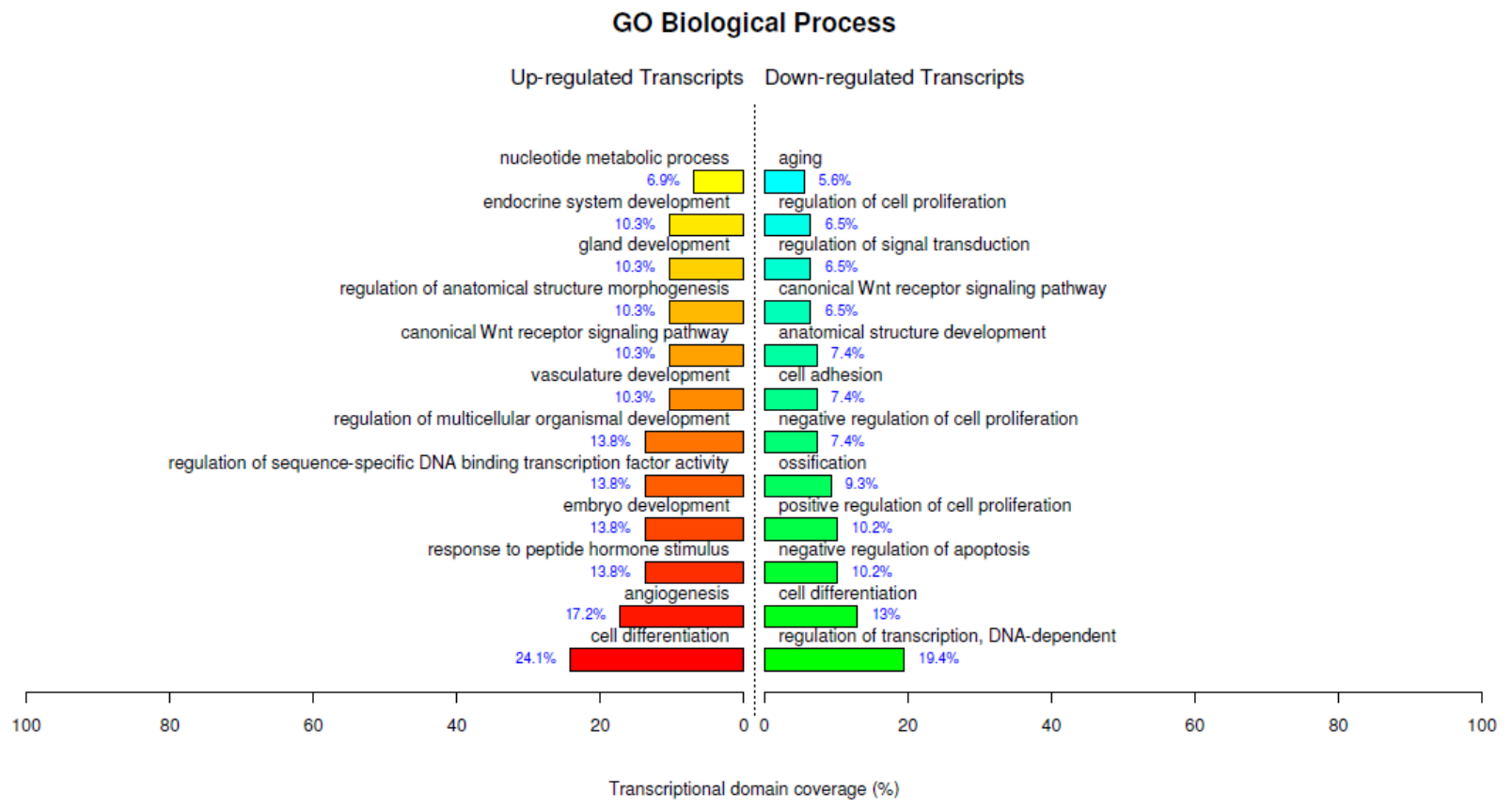

Os temas com genes hiper e hipoexpressos estão representados em vermelho e verde, respectivamente.

Figura 13 - Temas hiper-representados em KEGG e modulados via receptor AT2 no intervalo de 3 horas.

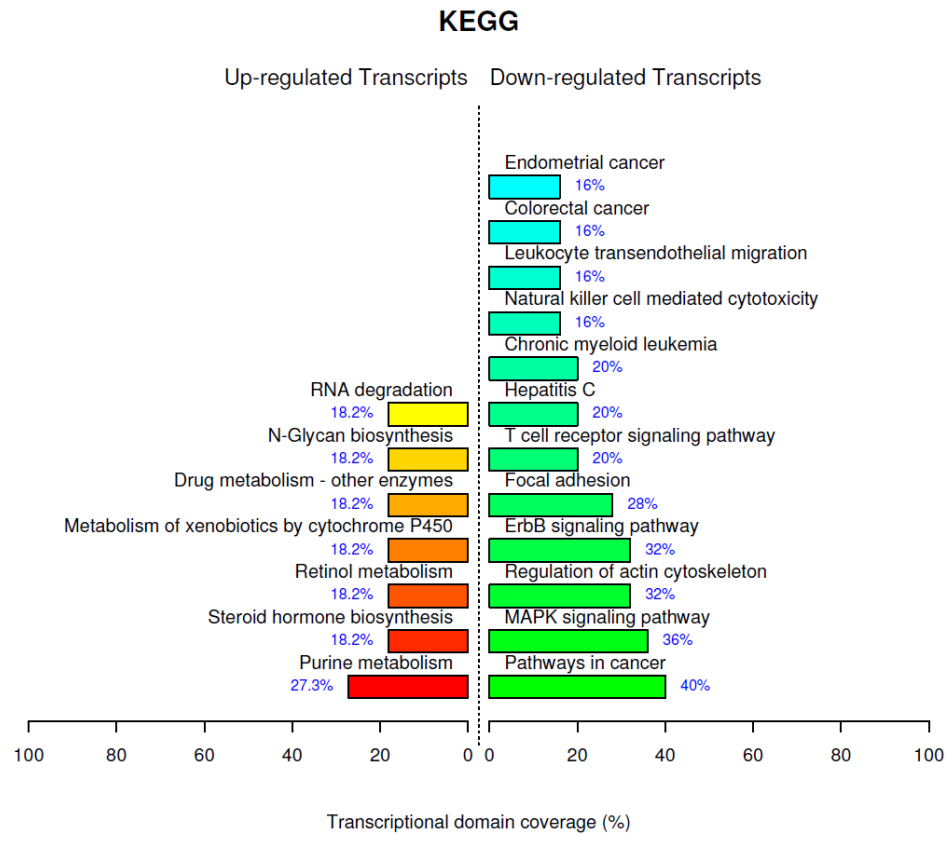

Os temas com genes hiper e hipoexpressos estão representados em vermelho e verde, respectivamente. 


\subsubsection{Intervalo de 6 horas de tratamento com Ang II e PD123319}

Os principais processos biológicos hiper-representados em GO nesse intervalo estão sumarizados na Figura 14. Os principais temas contendo genes hipoexpressos pela ação do PD123319 foram fosforilação de proteínas, transdução de sinal, regulação da transcrição, apoptose, transporte de proteínas, resposta a composto orgânico cíclico, regulação da proliferação celular e ciclo celular. Para os genes hiper-regulados, os processos biológicos hiper-representados foram regulação da transcrição, regulação da proliferação celular, transporte de proteínas, desenvolvimento do cérebro, transporte mediado por vesículas, resposta inflamatória, via de sinalização associada a receptores na superfície celular e cascata de NF-кB.

A análise realizada em KEGG está sumarizada na Figura 15. As principais funções com genes hipoexpressos foram via de sinalização de MAPK, vias em câncer, adesão focal, regulação do citoesqueleto de actina, ciclo celular, via de sinalização de neurotrofinas, transporte de RNA, migração celular, via de sinalização de ErbB, via de sinalização de p53 e gliomas. Já os genes hiperexpressos apresentaram como funções hiper-representadas relevantes: peroxissomo, via de sinalização de mTOR, via citossólica de sensoriamento de DNA, metabolismo de esfingolipídios e transporte vesicular em interações SNARE. 


\section{Figura 14 - Processos biológicos categorizados segundo GO e mediados pelo receptor AT2 no intervalo de 6 horas.}

\section{GO Biological Process}

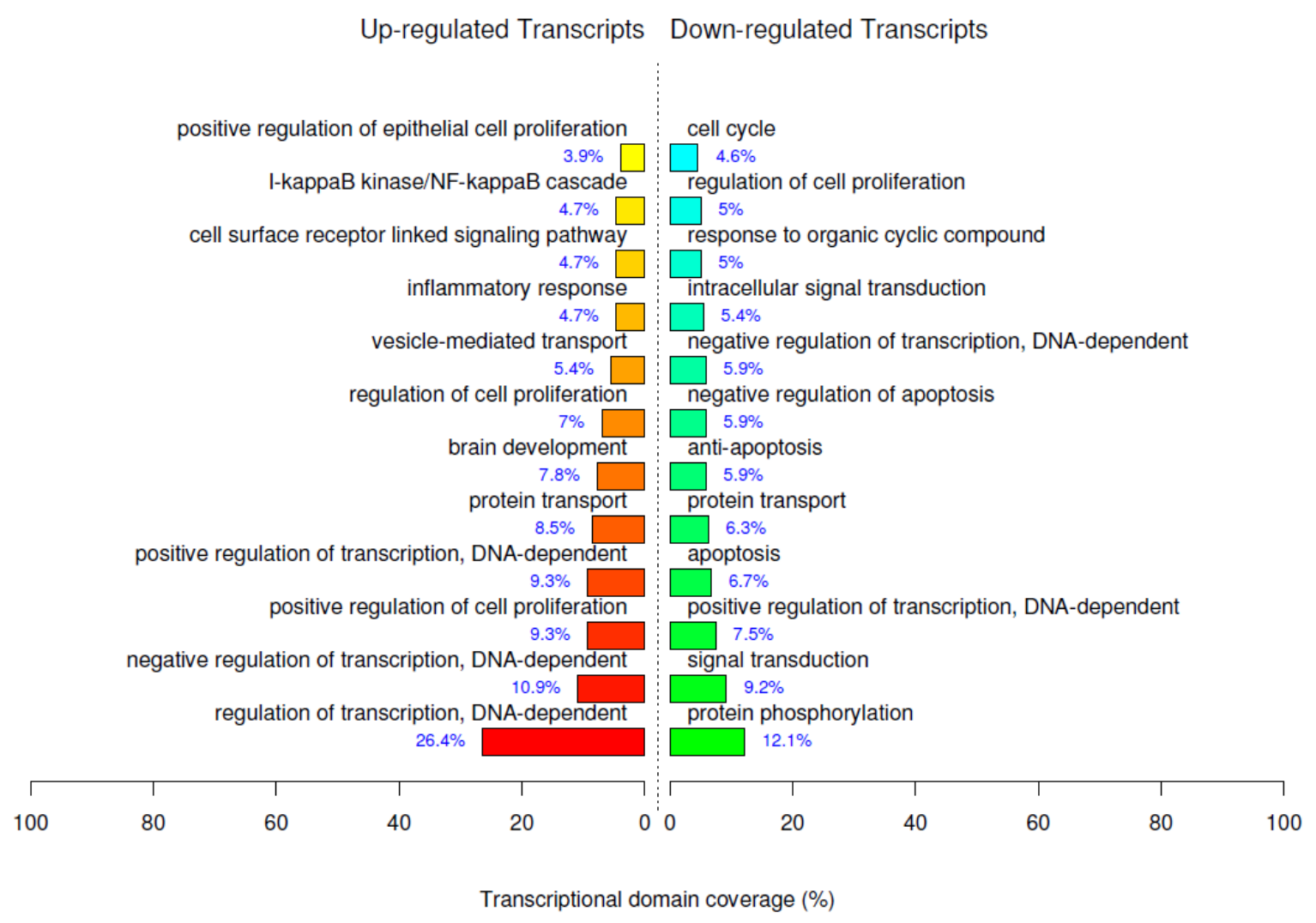

Os temas com genes hiper e hipoexpressos estão representados em vermelho e verde, respectivamente. 
Figura 15 - Temas hiper-representados em KEGG modulados via receptor AT2 no intervalo de 6 horas.

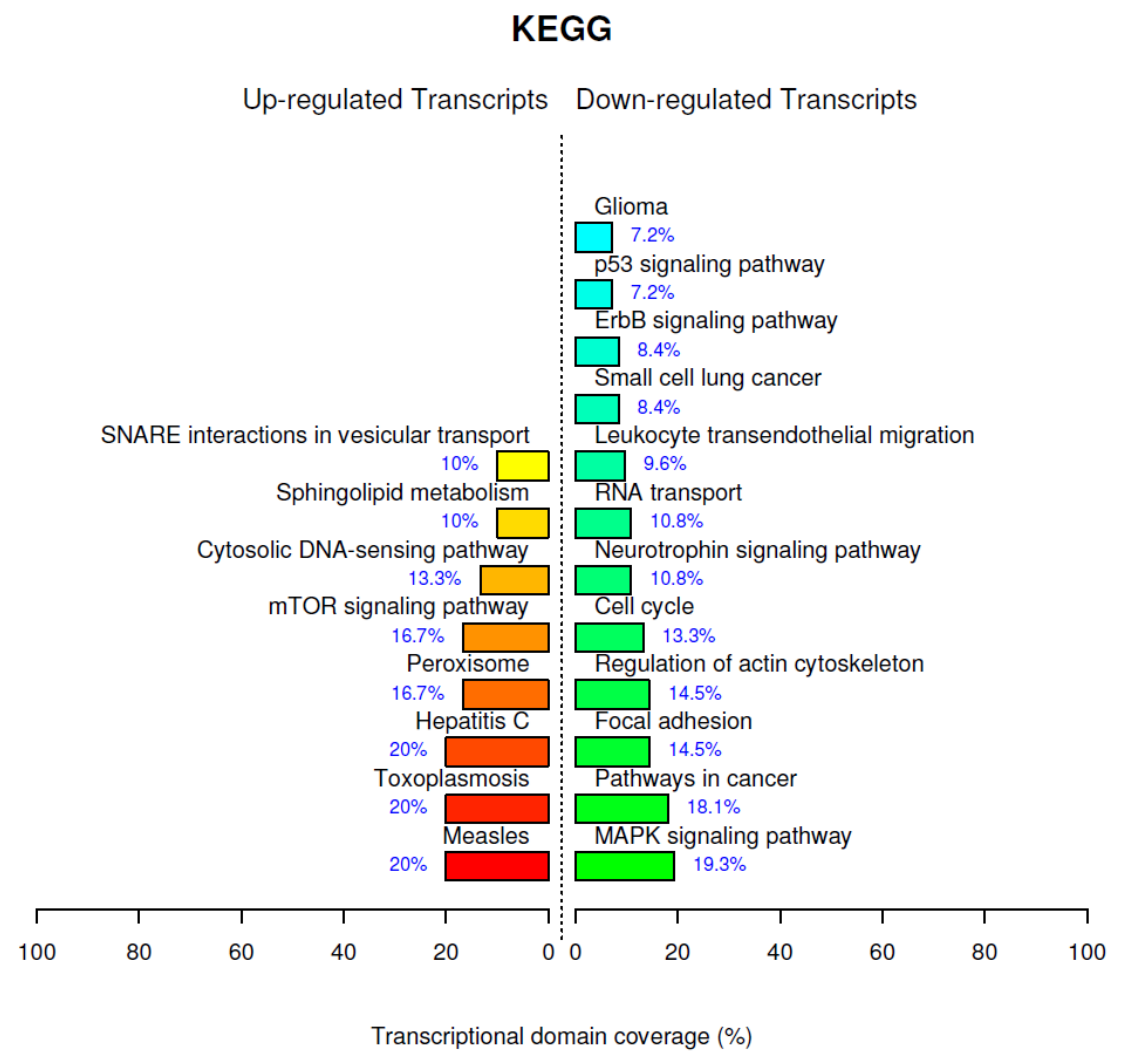

Os temas com genes hiper e hipoexpressos estão representados em vermelho e verde, respectivamente.

\subsection{Análises dos resultados dos perfis diferenciais de expressão gênica por Diagramas de Venn}

Diagramas de Venn foram construídos com o intuito de se identificar sobreposições entre os genes diferencialmente expressos encontrados em cada comparação realizada. Primeiro, visando identificar quais genes apresentaram expressão gênica diferencial em ambos os intervalos de tempo avaliados (3 e 6 horas), foram comparados os resultados obtidos para as mesmas comparações nesses intervalos de tempo. Nesse sentido, foram identificados genes regulados pela Ang II (Ang $x$ Control $3 \mathrm{~h}$ e Ang $\times$ Control 6h), regulados via receptor AT1 (Ang+Los $x$ Ang 3h e Ang+Los $x$ Ang 6h) e regulados via receptor AT2 (Ang+PD $x$ Ang 3 h e Ang+PD $x$ Ang 6h) em ambos os tempos estudados. A Figura 16 e 0 Quadro 3 contém os resultados obtidos pela análise previamente descrita. 
Figura 16 - Diagramas de Venn entre as mesmas comparações em 3 e $6 \mathrm{~h}$.

A

UP

Ang $x$ Control $3 h$

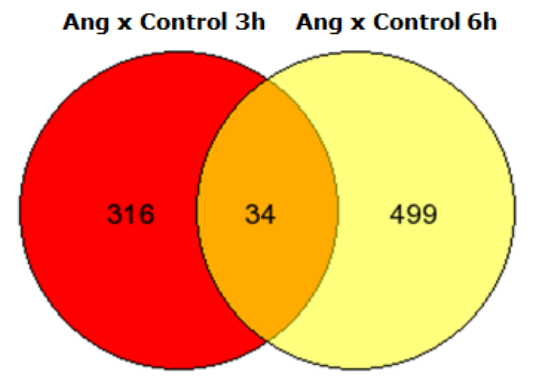

C

UP

Ang+Los $x$ Ang 3h Ang+Los $x$ Ang $6 h$

\section{Ang+Los $x$ Ang}

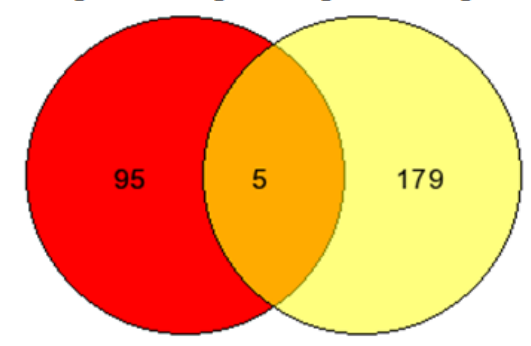

E

UP

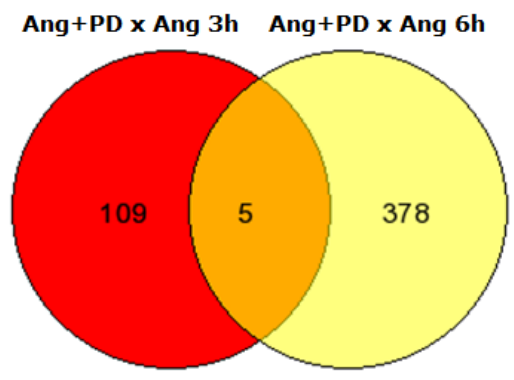

B

$$
\text { Down }
$$

Ang $\times$ Control 3h Ang $\times$ Control 6h

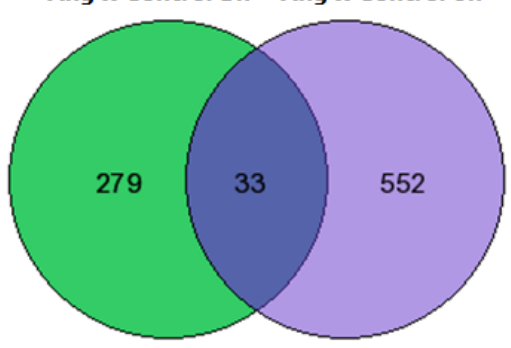

D

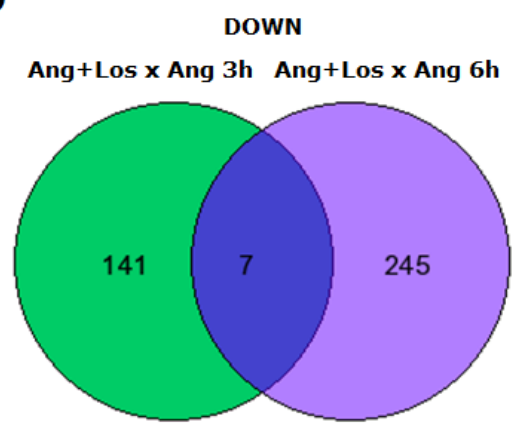

$\mathbf{F}$

Down

Ang+PD x Ang 3h Ang+PD x Ang 6h

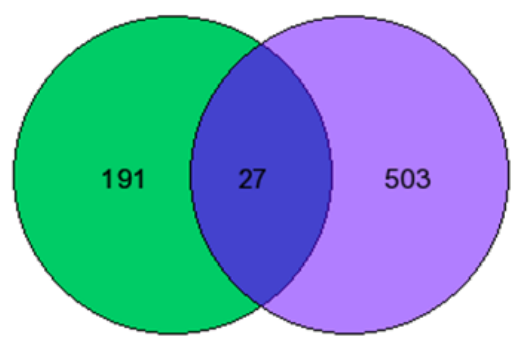

Genes hiperexpressos (A) e hipoexpressos (B) nos intervalos de 3 e 6 horas para a comparação Ang x Controle. Genes hiperexpressos (C) e hipoexpressos (D) nos intervalos de 3 e 6 horas para a comparação Ang+Los x Ang. Genes hiperexpressos (E) e hipoexpressos (F) nos intervalos de 3 e 6 horas para a comparação Ang+PD x Ang. 
Quadro 3 - Sobreposição dos resultados encontrados para as mesmas comparações nos intervalos de 3 e 6 horas.

Ang $\times$ Control

Ang+Los $x$ Ang

Ang+PD x Ang

Hiperexpressos

Hipoexpressos

Hiperexpressos Hipoexpressos Hiperexpressos

Cap1

Nab1

St13

Scnn1a

Rhbdl1

Agrp

Mpv1712

Bcar1

Jkamp

Hdgf

Mdk

Hipoexpressos

Nek2

Acp5

Lime1

Avpi1

Ndrg1

Prkca

Mapk1

Syt5

Sh3tc2

Dclk2

Hbegf

Il1rl1

Serbp1

Cacna1i

Acrbp

Dusp14

Stk19

Slc7a1

Rbm10

Ftsj1

Slc39a1

Sh2b3

Dock9

Zyx

Map2k4

Gpha2

Arhgap10

Ctgf

Srp54

Gdf7

Dusp6

Rbbp8

Ppp1r32

Pik3ca

Nkap

Cdig2

Rnf145

Pias1

Ncstn

Lrrc8c

Ipo9

Tmem208

Urb2

Ccdc18

Olr3

Mphosph10

Pibf1

Clcn6

Rrs1

Wdr33

Agtrap

Bcs1l

Tarsl2

Lypd2

Rev3l

Yipf3

Aggf1

Zfp395

Fam63a

Lrrc38

Rybp

Rexo1

Pex5

Ube2cbp

Mmgt2

Kat2a

Lats2

Fam198b

Rybp

Pea15a

Gabpb1I

Hsdl2 Mccc2

Elk1 Yap1

Atp10a

Psme4

Pid1

Anapc10

Best2

Cd3eap

Hebp1

Wdr96

Fam91a1

Ptpn3

RGD1562874

Prss36

Zfp709l2 Krtap1-3

Skiv2l2 Prr22

Taf9

LOC680443

Tcp11l1

Wfdc10

Dbr1

Lce1d

Atp6v1a 
Segundo, foram identificados os genes regulados ao mesmo tempo pela Ang II e via AT1, pela Ang II e via AT2 ou ainda pelos receptores AT1 e AT2. Considerando que a cinética da regulação da expressão gênica pode não ser igual nos grupos comparados, os resultados para as mesmas comparações nos intervalos de 3 e 6 horas foram combinados. Após esse procedimento, foram identificados respectivamente 117, 249 e 119 genes comuns nas comparações a) Ang x Controle e Ang+Los x Ang; b) Ang x Controle e Ang+PD x Ang e c) Ang+Los x Ang e Ang+PD $x$ Ang, conforme descrito na Figura 17.

Figura 17 - Diagrama de Venn entre os resultados para Ang II, AT1 e AT2.

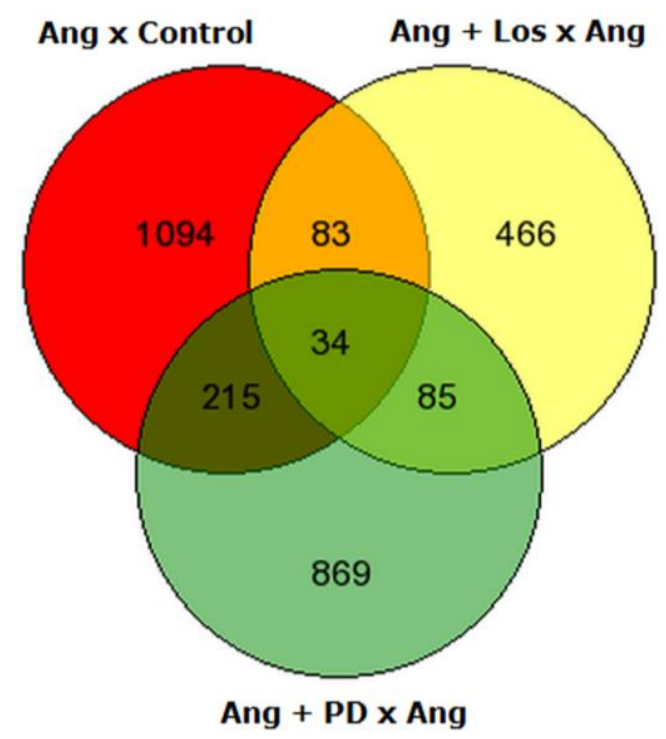

Posteriormente, foi realizado o enriquecimento funcional dos genes comuns encontrados nas comparações "a", "b" e "c", sendo que estes resultados estão contidos nas figuras 18 a 20. Como os genes hiperexpressos na comparação Ang $x$ Controle são encontrados hipoexpressos nas comparações Ang+Los x Ang ou Ang+PD $x$ Ang, optou-se por não se diferenciar quais genes são hiper ou hipoexpressos nessas figuras e, dessa forma, as barras representando a porcentagem de genes comuns em cada função biológica são somente de cor azul, ao invés das cores anteriores: vermelha (hiperexpressos) e verde (hipoexpressos).

Foi observado que em "a" as funções biológicas mais relevantes categorizadas em GO e KEGG foram transporte e ubiquitinação de proteínas, regulação do ciclo celular, resposta a íons metálicos, processamento de RNA, 
reabsorção de água regulada por vasopressina, vias de sinalização de mTOR e proteossomal. Em "b" as funções biológicas mais relevantes foram similares às observadas em a): transporte e ubiquitinação de proteínas, regulação do ciclo celular, resposta a íons metálicos, via de sinalização de MAPK, junções aderentes, processamento de proteínas no retículo endoplasmático, peroxissomos e ritmo circadiano. Em "c" as funções mais relevantes foram regulação da proliferação celular, regulação da apoptose, transporte, migração celular, vias de sinalização de Wnt, ErbB, mTOR, insulina, quimiocinas e Hedgehog, regulação do citoesqueleto de actina, leucemia mieloide aguda e ritmo circadiano.

Figura 18 - Enriquecimento funcional dos genes sobrepostos entre as comparações Ang x Controle e Ang + Los x Ang.

\section{a}

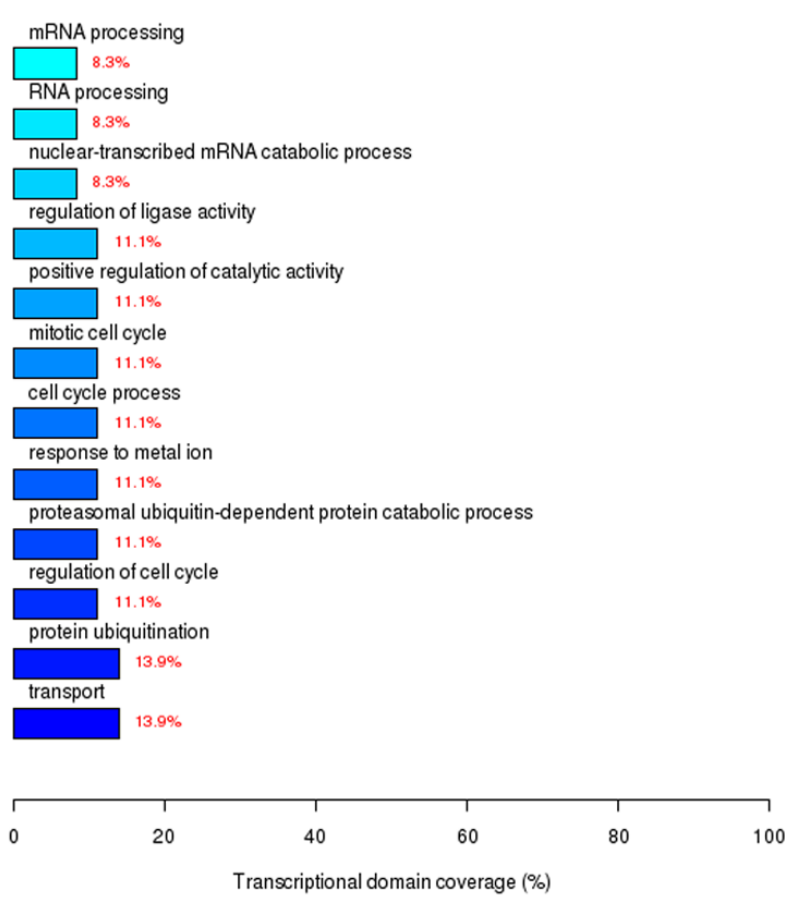

b KEGG

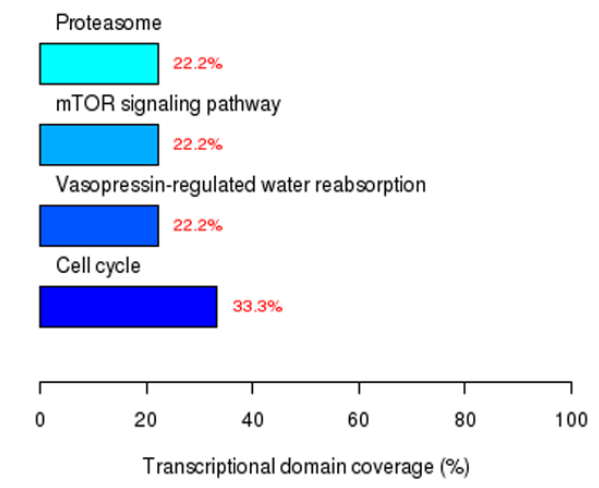

c

\begin{tabular}{cc}
\hline $\begin{array}{c}\text { GO / KEGG function } \\
\text { trans port } \\
\begin{array}{c}\text { protein ubiquitination } \\
\text { and proteasome }\end{array} \\
\text { cell cycle }\end{array}$ & $\begin{array}{c}\text { Gync1i2, Slc25 246, Srpr, Pea15a, Pigz } \\
\text { Psmd9, Psme3, Rnf187, Psmf1, Rnf168 } \\
\text { Chek2, Cdc25b, Mcm5, Eif4e, Mnt, Srsf5, } \\
\text { Hexim2, Psmd9, Psme3, Psmf1, Mlh1 }\end{array}$ \\
$\begin{array}{c}\text { response to metal ion } \\
\text { RNA processing } \\
\text { vasopress in-regulated } \\
\text { water reabsorption }\end{array}$ \\
$\begin{array}{c}\text { Aqp2, Acp5, Cdig2, Sec31a } \\
\text { mTOR signaling pathway }\end{array}$ & Dync1i2, Aqp2 \\
\hline
\end{tabular}




\section{Figura 19 - Enriquecimento funcional dos genes sobrepostos entre as comparações Ang x Controle e Ang + PD x Ang.}

$\mathbf{a}$

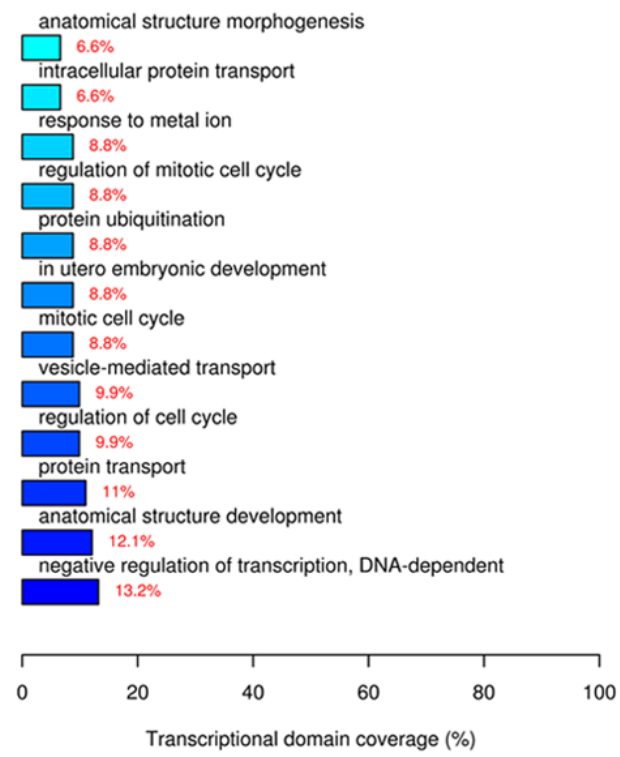

b

KEGG

C

GO / KEGG Functions
MAPK signaling pathway
Protein processing in endoplasmic reticulum
RNA transport
Tight junction
Cell cycle related functions
Leukocyte trans endothelial migration
Protein Ubiquitination and Proteolysis
Peroxisome
Chronic myeloid leukemia
Circadian rhythm - mammal
Protein trans port
Response to metal ion

Genes

Hspa8, Mapkapk2, Pak2, Mecom, Ppp311, Rras, Sos2

Hspa8, Capn2, Sar1a, Eif2ak2, Bag2, Sec31a

Eif4e, Eif4a1, Pigz, Sumo2, Eif2 b2

Magi3, Gnai3, Cldn9, Myl9, Rras

Ccnb1, Skp2, Mcm4, Hdac1, Anapc10, Gtpbp4, Eif4e, Hspa8, Fignl1,

Ctbp1, Mecom, Brd4, A pbb1, Rnf2, Ptnp3, Chmp1a, Thap1, Top2a Gnai3, Cldn9, Myl9, Vcl, Ctnnd1

Skp2, Ube2a1, Pias1, KIhl13, Anapc10, Zfp91, Ccnb1, Ltn1, Rnf 2, Frwd3

Pex19, Paox, Pex14, Agps

Ctbp1, Mecom, Hdac1, Sos2

$$
\text { Rora, Npas } 2
$$

Response to metal ion 
Figura 20 - Enriquecimento funcional dos genes sobrepostos entre as comparações Ang + Los x Ang e Ang + PD x Ang

$\mathbf{a}$

GO Biological Process

b

KEGG
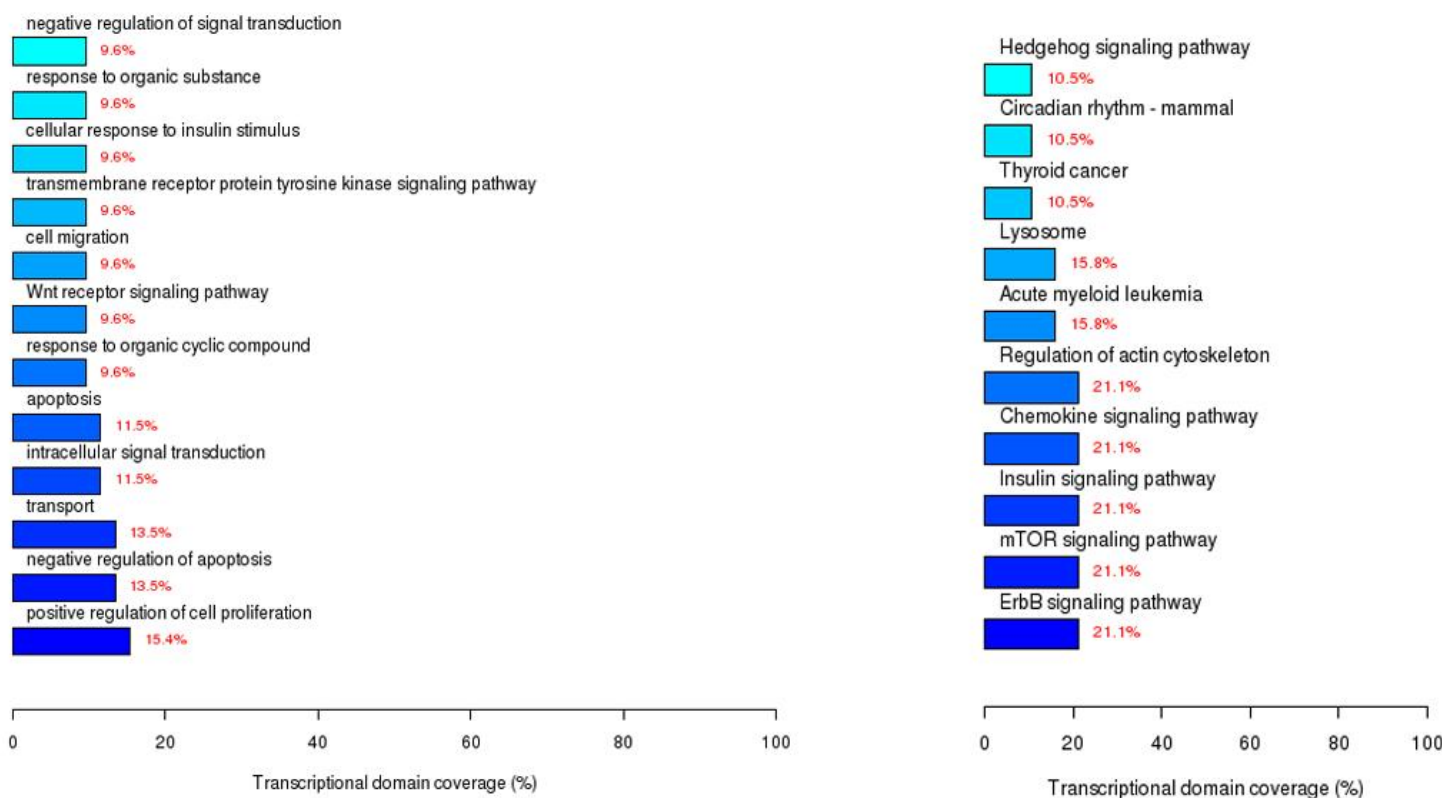

c

\begin{tabular}{cc}
\hline GO / KEGG Functions & Genes \\
Regulat ion of cell prolifer ation & Myc, Irs1, Ccl24, Myd88, Ngf, Sox4, Nolc1, Bambi \\
Regulation of apoptosis & Myc, Cd44, Myd88, Ngf, Pea15a, Sox4, Birc5 \\
Transport & Slc29a4, Copz2, Cyb561d2, Pea15a, Dynll1, Pigz, Abca2 \\
Cell migration & Cd44, Bcar1, Kctd13, G sk3a, Bambi \\
ErbB signaling pathway & Eif4ebp1, Myc, Pak1, Rps6 kb2 \\
mTOR signaling pathway & Eif4ebp1, Eif4e, Ulk1, Rps6kb2 \\
Insulin signaling pathway & Eif4ebp1, Eif4e, Irs1, Rps6 kb2 \\
Chemokine signaling pathway & Bcar1, Ccl24, Pak1, Gsk3a \\
Hedgehog signaling pathway & Csnk1e, Dhh \\
Wnt receptor signaling pathway & Myc, Cd44, Sox4, Csnk1e, Bambi \\
Regulation of actin cytoskeleton & Bcar1, Pak1, Mylg, Rras \\
Acute myeloid leukemia & Eif4 ebp1, Myc, Rps $6 \mathrm{~kb} 2$ \\
Thyroid cancer & Myc, Ccdc6 \\
Lysosome & Cdig2, Mcoln1, Abca2 \\
Circadian rhythm - mammal & Arntl, Csnk1e \\
\hline
\end{tabular}




\subsection{Redes de Interatoma}

Os genes diferencialmente expressos obtidos em cada comparação foram submetidos a análises de interatoma, as quais revelam a partir das relações entre as proteínas codificadas por esses genes o panorama global físico e funcional de um sistema biológico (IDEKER; KROGAN, 2012). Os interatomas foram construídos utilizando o plug-in Bisogenet do Cytoscape. As análises foram limitadas às proteínas codificadas pelos genes diferencialmente expressos encontrados e também às proteínas que interagem diretamente com essas proteínas. As relações funcionais entre as proteínas são baseadas em dados da literatura, os quais são imputados em bancos de dados acessados pelo Bisogenet.

Uma rede de interação é constituída de nós (i.e. proteínas) que são interconectados por arestas, sendo que a expressão diferencial de determinadas proteínas pode ativar ou inibir as proteínas associadas a essa rede. Portanto, é fundamental reconhecer as proteínas que apresentem maior relevância ou controle sobre as redes. Neste trabalho, as proteínas com maior relevância foram identificadas a partir de uma medida de centralidade na qual os nós com cinco ou mais interações foram considerados centrais nas respectivas redes, sendo denominados hubs.

Os interatomas construídos a partir das comparações realizadas estão apresentados nas figuras 21 a 26. Em resumo, os quadros 4 e 5 ilustram os hubs encontrados nas diferentes comparações, bem como suas possíveis funções na biologia dos gliomas. 


\section{Quadro 4 - Lista de Hubs encontrados em cada interatoma.}

Comparação entre os grupos

Ang $x$ Control $3 \mathrm{~h}$

Ang $\times$ Control $6 \mathrm{~h}$

Ang+Los $x$ Ang 3h

Ang+Los $x$ Ang $6 h$

Ang+PD $x$ Ang $3 \mathrm{~h}$

Ang+PD $x$ Ang $6 \mathrm{~h}$
Hubs

Kras, Apc, Prkca, Gja1, Ubc, Sumo3, Akt1, Mapk1, Mapk3, Dlg1, Dlg4, Grip1, Ctnnb1

Calm2, Cdk5, Sumo1, Sumo3, Ntrk1, Ntrk2, Cdk5r1, Grb2, Ubc, Gipc1, Ppp1r9b, Dapk3, Rask, Stx1a, Ywhah, Mapk1, Snap23, Mk03, Dlg4, Kpca

$$
\text { Mapk3, Tp53 e Myc }
$$

Mapk3, Sdc2, Ubc, Ngfr, Arrb2, Sumo3, Dlg4, Irs1

Prkca, Myc, Ubc, Itgb1, Mapk3

Mapk3, Sumo3, Prkca, Irs1, Stxbp1, Ubc, Shank1,

Shank3, Dlg4, Homer1, Grip1

\section{Quadro 5 - Hubs encontrados nas análises dos interatomas e suas possíveis funções biológicas e associação com gliomas.}

\begin{tabular}{|c|c|c|c|}
\hline Hubs & Funções & $\begin{array}{l}\text { Associado } \\
\text { a gliomas? }\end{array}$ & Referência \\
\hline Akt1 & Sobrevivência e crescimento celular & Sim & Chen et al., 2011 \\
\hline Apc & Gene supressor de tumor & Não & \\
\hline Arrb2 & $\begin{array}{l}\text { Dessenssibilização de receptores acoplados a } \\
\text { proteína G }\end{array}$ & Não & \\
\hline Calm2 & Mediador da sinalização de cálcio & Não & \\
\hline Cdk5 & $\begin{array}{l}\text { Media a migração de células de glioblastoma } \\
\text { humanas induzida por fatores de crescimento }\end{array}$ & Sim & Liu et al., 2008 \\
\hline Cdk5r1 & $\begin{array}{l}\text { Ativador de Cdk5 / associado a progressão de } \\
\text { meningiomas / via de sinalização de Wnt }\end{array}$ & Não & Wrobel et al., 2005 \\
\hline Ctnnb1 & Via de sinalização de Wnt & Sim & Nager et al., 2012 \\
\hline Dapk3 & $\begin{array}{l}\text { Gene supressor de tumor: mutações promovem } \\
\text { aumento da sobrevivência e proliferação celular }\end{array}$ & Não & Brognard et al., 2011 \\
\hline Dlg1 & Invasão e migração celular & Não & \\
\hline Dlg4 & Invasão e migração celular & Não & \\
\hline Gipc1 & $\begin{array}{l}\text { Proteína estrutural / interage com complexos de } \\
\text { sinalização de receptores/ tumorigênese }\end{array}$ & Não & Chittenden et al., 2010 \\
\hline
\end{tabular}



Yu et al., 2012 indiferenciado de células-tronco em gliomas Via de Ras-Shc-Grb2 está associada ao

Grb2 comportamento maligno em células de gliomas

Grip1 Proteína estrutural / essencial para o efeito de GluR2 na inativação de ERK-Src e subsequente indução da apoptose

Homer1 Proteína adaptadora

Irs1 Proliferação celular / transmite sinal dos receptores de insulina para as vias de PI3K e MAP cinases

Itgb1 Adesão celular / difusão de células tumorais

Kpca Processamento de proteínas precursoras

Kras A sinalização de Kras-Raf está associada com a indução de gliomas em modelos animais

Mapk1 Proliferação celular / via das MAP cinases

Mapk3 Proliferação celular / via das MAP cinases

Mk03 Via das MAP cinases / expressão em câncer de mama

Myc Regula a proliferação e a sobrevivência de células-tronco em gliomas

Ngfr Fator de crescimento que regula o crescimento, diferenciação e apoptose no sistema nervoso / expressão em astrocitomas

Ntrk1 Membro da família de NTRK / associação inversa da expressão de TrkA com a malignidade dos gliomas

Ntrk2 Membro da família de NTRK / expressão em astrocitomas

Ppp1r9b Proteína estrutural / contribui para 0 Não desenvolvimento de câncer de pulmão

Prkca Migração de células de glioma C6

Rask Desenvolvimento de neoplasias / Ativação somatic de Rask em carcinomas ovarianos

Sdc2 Influencia a sensibilidade de GBMs à Sim quimioterapia com semustina/ Associado com angiogênese

Shank1 Proteína estrutural
Sim

Sim

Prigent et al., 1996

Beretta et al., 2009

Não

Sim

Knobbe et al., 2003

Sim

Edwards et al., 2011

Não

Sim

Lyustikman et al., 2008

Sim

Glassmann et al., 2011

Sim

Não

Czerwenka et al., 2001

Sim

Wang et al., 2008

Sim

Sim

Hansen et al., 2007

Sim

Wang et al., 1998
Não

Zhao et al., 2011

Molina-Pinelo et al., 2011

Hu et al., 2010

Feig et al., 1994

Não 
Shank3 Proteína estrutural

Snap23 Regula o transporte por vesículas / expresso em células de gliomas

Stx1a Inibe canais iônicos em células de gliomas

Stxbp1 Liga à sintaxina e co-purifica com a cinase cdc2like / expressão em gliomas

Sumo1 Sumoilação da Vimentina / promoção da inibição da migração de células de gliomas

Sumo3 Sumoilação de proteínas como Gja1

Tp53 Gene suppressor de tumor / mutações associadas ao desenvolvimento de gliomas

Ubc Ubiquitinação de proteínas

Ywhah Proteína adaptadora implicada na regulação de vias de sinalização / deleções homozigóticas identificadas em GBMs
Não

Sim Volknandt et al., 2002

Sim

Berdiev et al., 2003

Sim

Kalida et al., 2000

Sim

Wang et al., 2010

Não

Sim

Não

Sim 
Figura 21 - Interatoma obtido a partir das proteínas codificadas por genes diferencialmente expressos encontrados na comparação Ang $x$ Controle 3h.

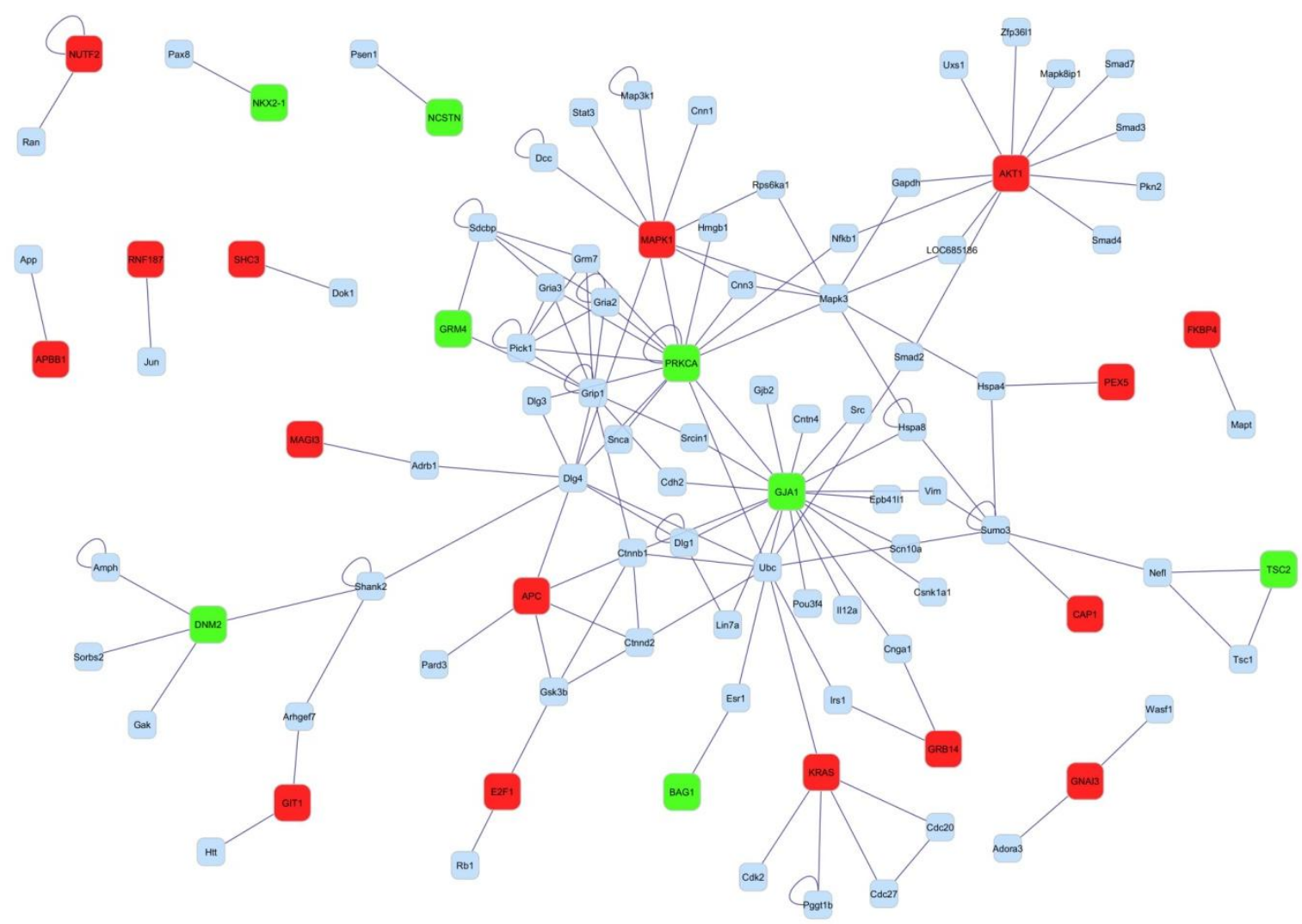

As proteínas diferencialmente expressos estão representados em vermelho (hiperexpressos) e verdes (hipoexpressos). As proteínas codificadas por genes não presentes nos resultados de expressão gênica diferencial aparecem em azul. Os hubs encontrados foram Kras, Apc, Prkca, Gja1, Ubc, Sumo3, Akt1, Mapk1, Mapk3, Dlg1, Dlg4, Grip1 e Ctnnb1. 
Figura 22 - Interatoma obtido a partir das proteínas codificadas por genes diferencialmente expressos encontrados na comparação Ang $x$ Controle 6h.

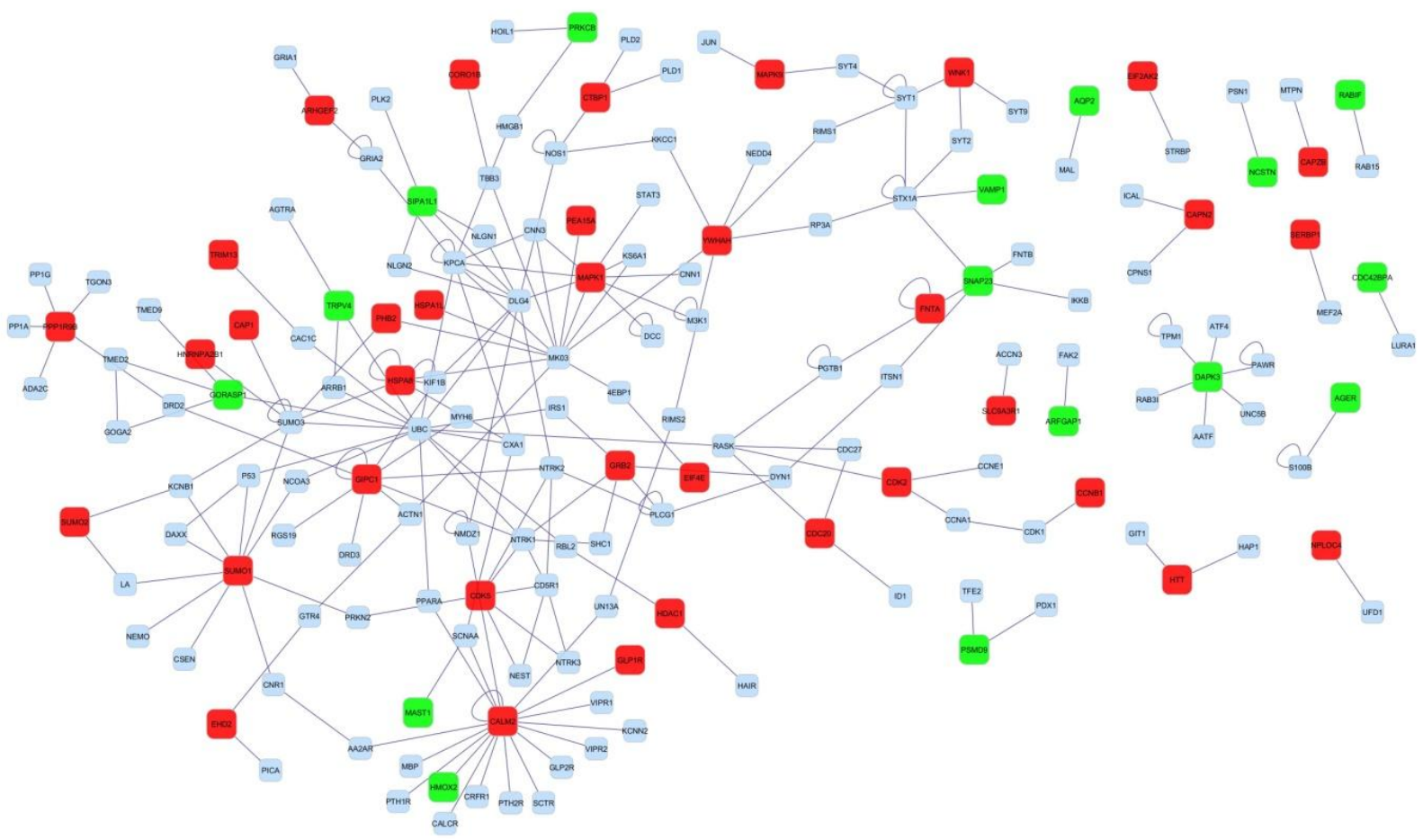

As proteínas diferencialmente expressos estão representados em vermelho (hiperexpressos) e verdes (hipoexpressos). As proteínas codificadas por genes não presentes nos resultados de expressão gênica diferencial aparecem em azul. Os hubs encontrados foram Calm2, Cdk5, Sumo1, Sumo3, Ntrk1, Ntrk2, Cd5r1, Grb2, Ubc, Gipc1, Ppp1r9b, Dapk3, Rask, Stx1a, Ywhah, Mapk1, Snap23, Mk03, Dlg4 e Kpca. 
Figura 23 - Interatoma obtido a partir das proteínas codificadas por genes diferencialmente expressos encontrados na comparação Ang+Los $\mathrm{x}$ Ang $3 \mathrm{~h}$.

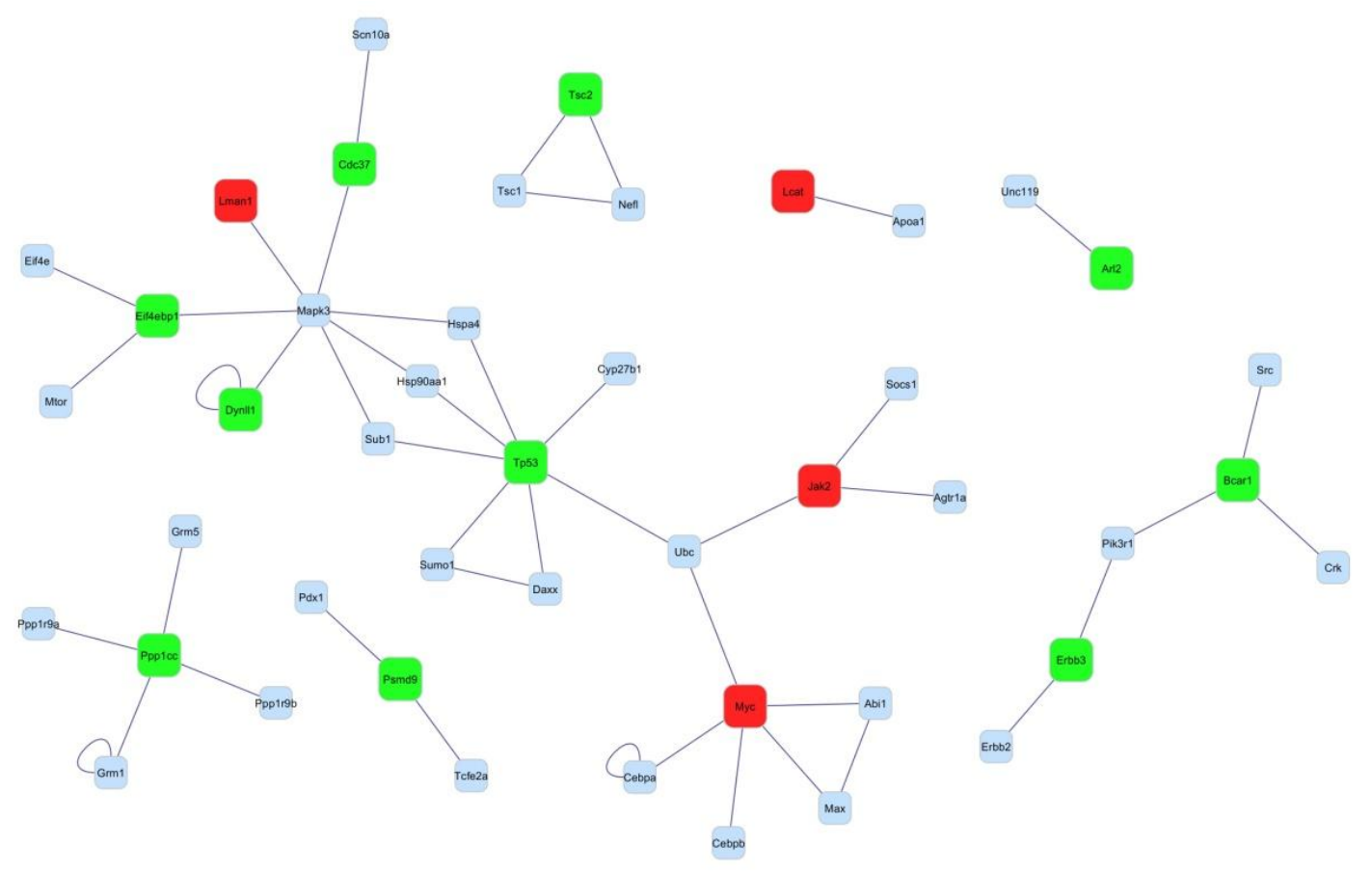

As proteínas diferencialmente expressos estão representados em vermelho (hiperexpressos) e verdes (hipoexpressos). As proteínas codificadas por genes não presentes nos resultados de expressão gênica diferencial aparecem em azul. Os hubs encontrados foram Mapk3, Tp53 e Myc. 
Figura 24 - Interatoma obtido a partir das proteínas codificadas por genes diferencialmente expressos encontrados na comparação Ang+Los $\mathrm{x}$ Ang $6 \mathrm{~h}$.

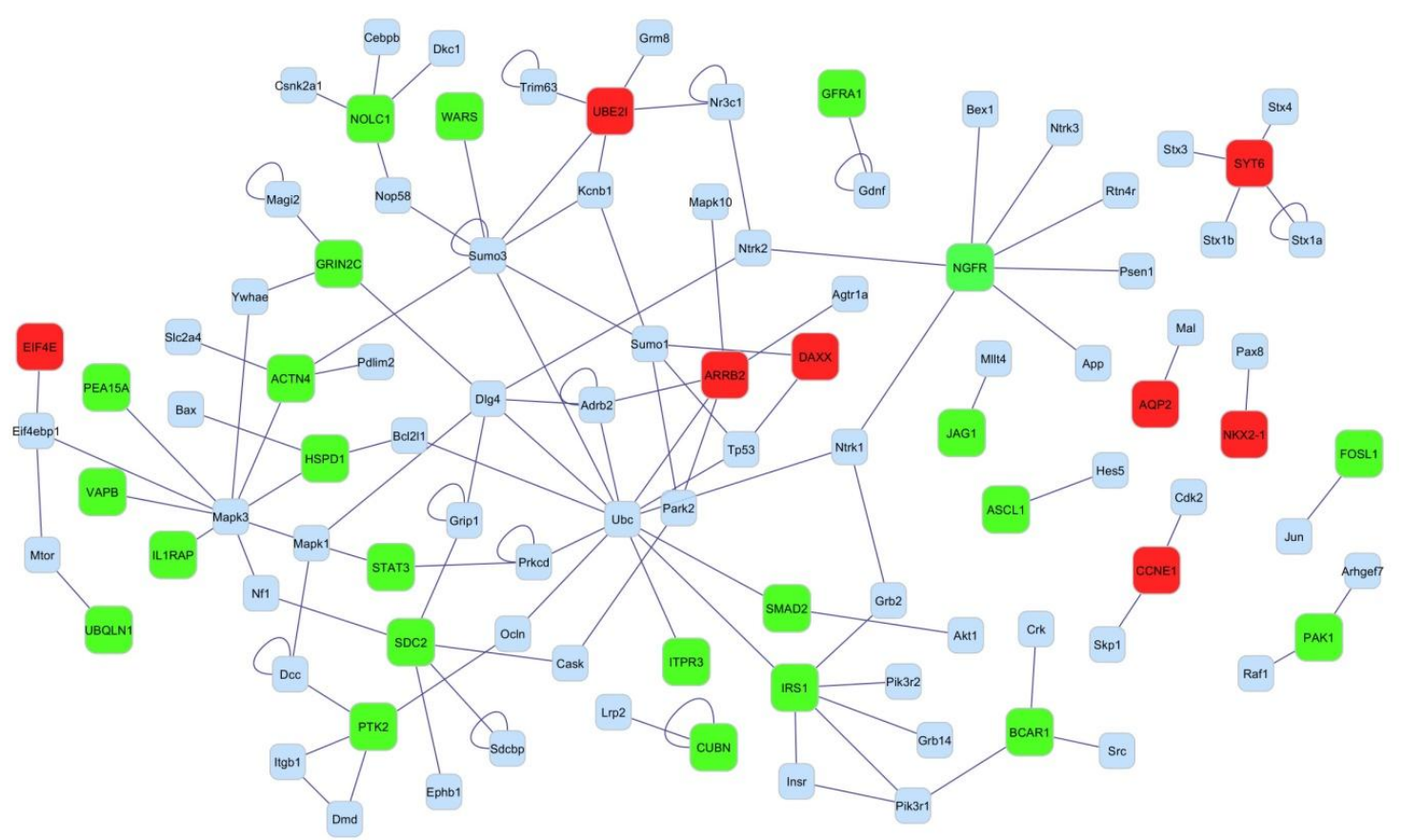

As proteínas diferencialmente expressos estão representados em vermelho (hiperexpressos) e verdes (hipoexpressos). As proteínas codificadas por genes não presentes nos resultados de expressão gênica diferencial aparecem em azul. Os hubs encontrados foram Mapk3, Sdc2, Ubc, Ngfr, Arrb2, Sumo3, Dlg4 e Irs1. 
Figura 25 - Interatoma obtido a partir das proteínas codificadas por genes diferencialmente expressos encontrados na comparação Ang+PD $x$ Ang 3h

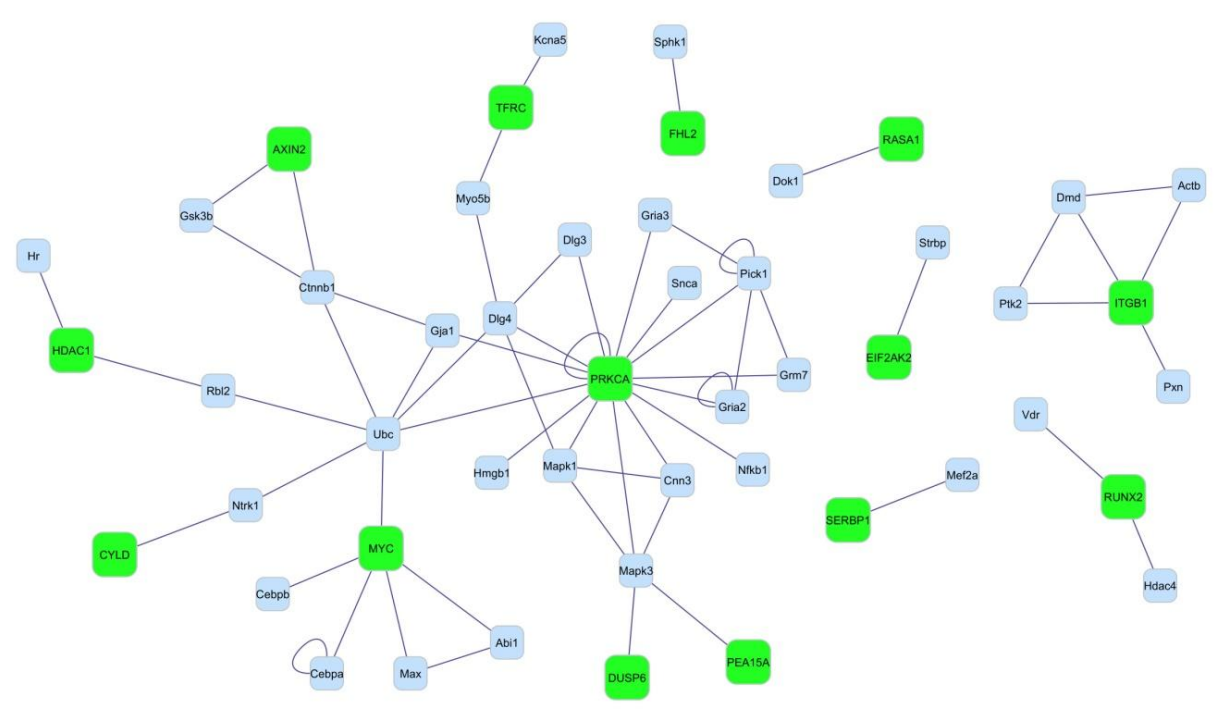

As proteínas diferencialmente expressos estão representados em vermelho (hiperexpressos) e verdes (hipoexpressos). As proteínas codificadas por genes não presentes nos resultados de expressão gênica diferencial aparecem em azul. Os hubs encontrados foram Prkca, Myc, Ubc, Itgb1 e Mapk3. 
Figura 26 - Interatoma obtido a partir das proteínas codificadas por genes diferencialmente expressos encontrados na comparação Ang+PD x Ang 6h.

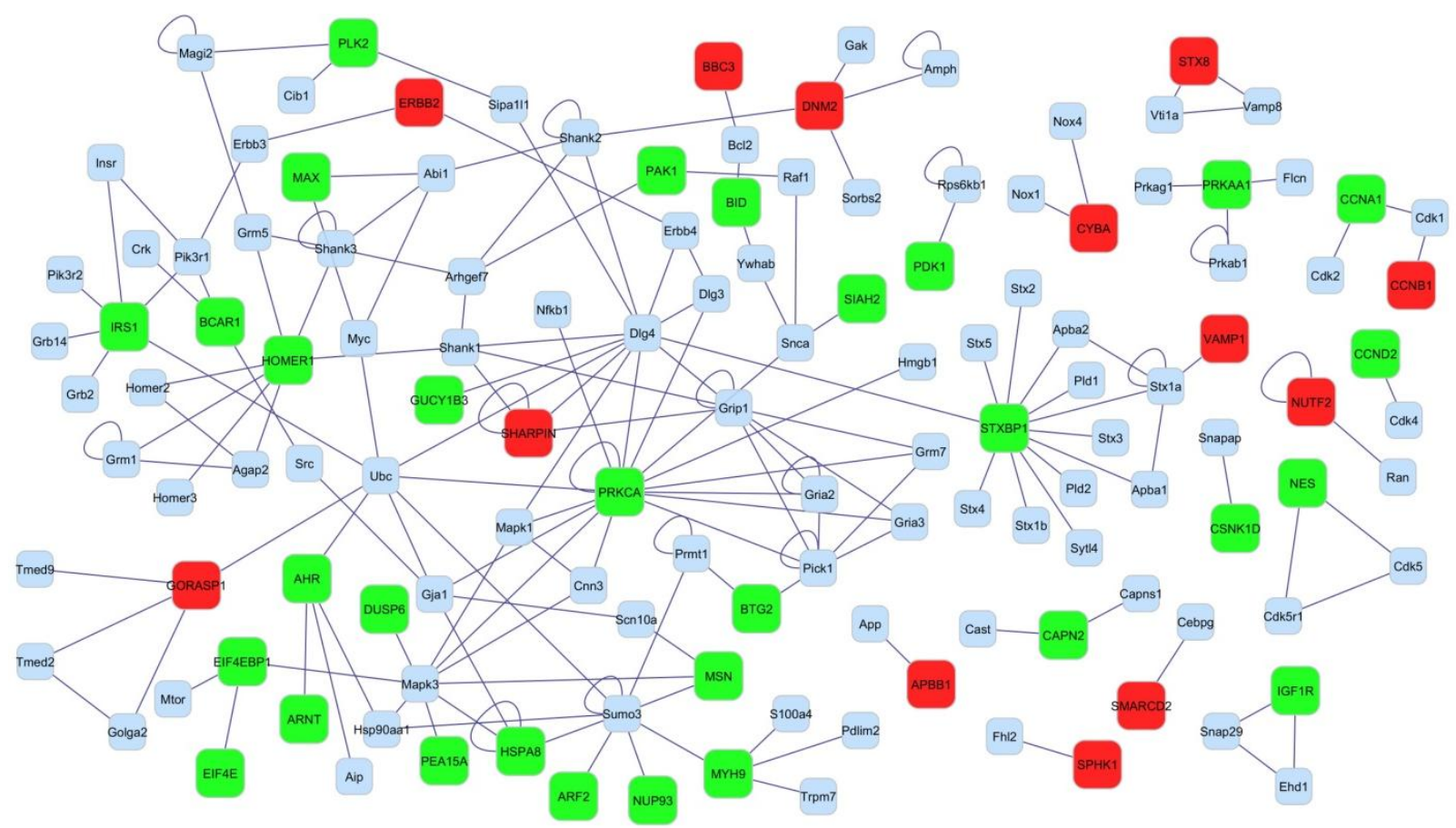

As proteínas diferencialmente expressos estão representados em vermelho (hiperexpressos) e verdes (hipoexpressos). As proteínas codificadas por genes não presentes nos resultados de expressão gênica diferencial aparecem em azul. Os hubs encontrados foram Mapk3, Sumo3, Prkca, Irs1, Stxbp1, Ubc, Shank1, Shank3, Dlg4, Homer1 e Grip1. 


\subsection{Validação dos resultados de DNA microarray por qPCR}

A partir da seleção de alguns genes diferencialmente expressos encontrados nas análises de DNA microarray, buscamos validar os resultados desses genes utilizando a técnica de qPCR. Foram desenhados primers para os genes selecionados utilizando o programa Primer $3^{\circledR}$. Esses genes e seus respectivos primers estão contidos no Quadro 6.

\section{Quadro 6 - Genes diferencialmente expressos nas análises de DNA microarray que foram selecionados para posterior validação por qPCR.}

\begin{tabular}{|c|c|c|}
\hline Genes & Nome dos Primers & Sequencia (5' para 3') \\
\hline \multirow{2}{*}{ Map2k4 } & MAP2K4 FW & GTGGACAGCTCGTGGACTCTAT \\
\cline { 2 - 3 } & MAP2K4 RV & TCATACCCTTGTCTTGATGCAC \\
\hline \multirow{2}{*}{ Prkca } & PRKCA FW & ATGCTCATGTTTCCAGTCTGC \\
\cline { 2 - 3 } & PRKCA RV & CTGATAGAGTGCCAGTGTGTGG \\
\hline \multirow{2}{*}{ Agtrap } & AGTRAP FW & CAAAGAAGACAAGAAGCCCAAG \\
\cline { 2 - 3 } & AGTRAP RV & AGCGCTCTACCACTGAGCTAAA \\
\hline \multirow{2}{*}{ Ccl2 } & CCL2 FW & CCTGTTGTTCACAGTTGCTGCC \\
\cline { 2 - 3 } & CCL2 RV & TCTACAGAAGTGCTTGAGGTGGTTG \\
\hline \multirow{2}{*}{ Mmp9 } & MMP9 FW & CCCCACTTACTTTGGAAACGC \\
\cline { 2 - 3 } & MMP9 RV & ACCCACGACGATACAGATGCTG \\
\hline
\end{tabular}

Os resultados encontrados por qPCR foram de acordo com os encontrados nos experimentos de DNA microarray, corroborando os resultados de expressão gênica diferencial desses genes. Os resultados comparativos entre os experimentos de DNA microarray e qPCR encontram-se na Figura 27. 
57

Figura 27 - Validação dos resultados de DNA microarray por qPCR.

DNA microarray results

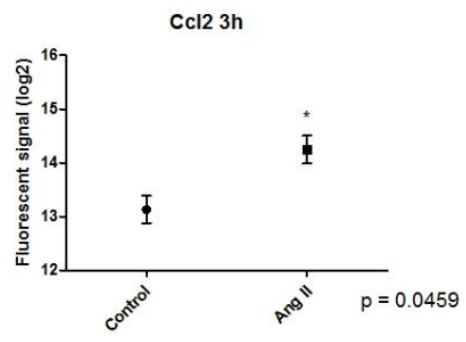

Prkca 3h

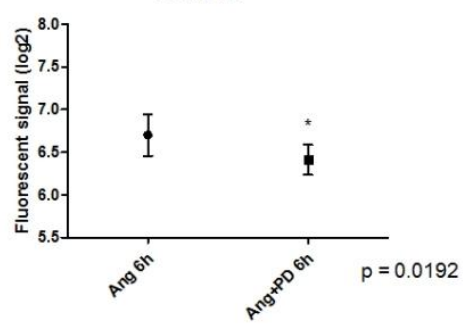

Map2k4 3h

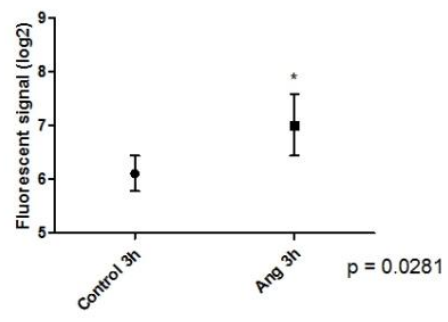

Agtrap 3h

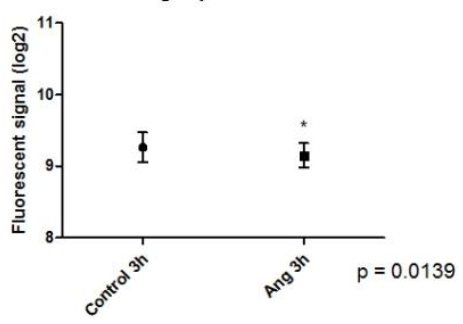

Mmp9 3h

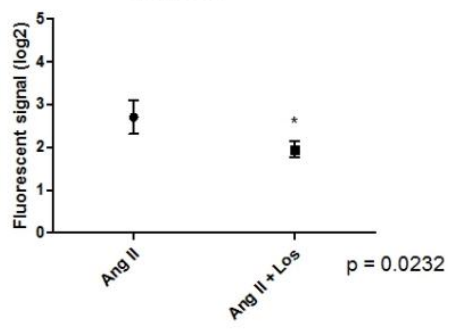

qPCR Results

$\mathrm{Ccl} 23 \mathrm{~h}$

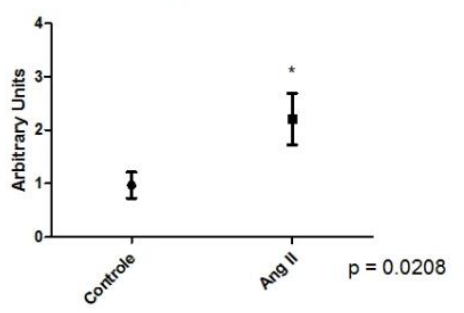

Prkca 3h

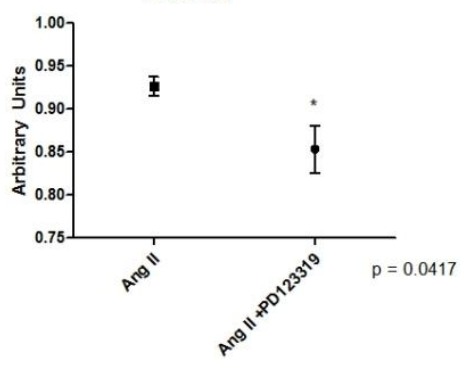

Map2k4 3h

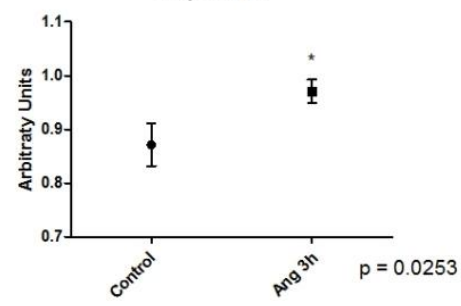

Agtrap

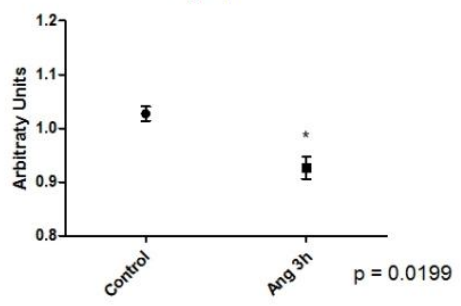

Mmp9 3h

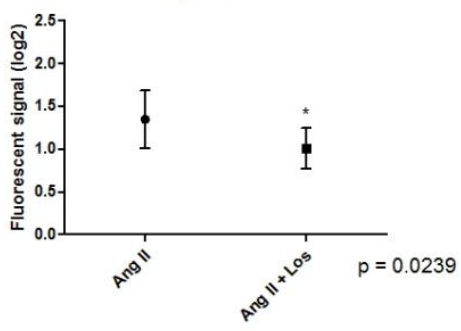

Comparação entre os resultados obtidos nos experimentos de DNA microarray e qPCR para os genes Ccl2, Prkca, Map2k4, Agtrap e Mmp9. 


\section{DISCUSSÃo}

\subsection{Análise funcional do transcriptoma induzido pela ativação global dos receptores AT1 e AT2 de Ang II}

Conforme visto na seção anterior, os processos biológicos mais relevantes categorizados em GO nos intervalos de 3 e 6 horas (Ang x Controle) foram regulação da transcrição, ciclo e divisão celular, transporte de proteínas, ubiquitinação de proteínas, fosforilação de proteínas, organização do citoesqueleto de actina, desenvolvimento do cérebro, regulação da proliferação celular e da apoptose, reparo do DNA, regulação da migração celular, vias em câncer e doença de Parkinson. Já as vias de sinalização mais relevantes categorizadas em KEGG foram: MAP cinases, adesão focal, quimiocinas, ErbB, neurotrofinas, insulina, TGF$\beta$, PPAR, mTOR e Notch.

O achado da hiperexpressão de genes relacionados à via ubiquitinaproteossomal indica que a Ang II pode interferir diretamente na regulação do ciclo celular a partir da utilização dessa via. As transições de fase (mitose-intérfase) durante o ciclo celular são controladas pela ativação das cinases dependentes de ciclinas. Por conseguinte, a via ubiquitina-proteossomal, ao sinalizar a degradação das ciclinas, gera uma oscilação periódica que é capaz de realizar as mudanças entre mitose e intérfase (WASCH et al., 2005), levando por fim a um aumento na taxa de proliferação do tumor. Assim, pode-se admitir a hipótese de que o aumento da proliferação promovida pela Ang II em células C6 encontrado por Rivera et al. (2001) poderia ser ocasionado em parte pela hiperexpressão de genes da via ubiquitina-proteossomal. Entretanto, estudos confirmatórios centrados nessa via molecular devem ser realizados para comprovar essa hipótese.

Temas relacionados ao reparo do DNA também foram identificados. Estudos recentes têm sugerido que a resistência ao agente alquilante temozolomida (TMZ), quimioterápico que sensibiliza as células do glioma à radioterapia, pode estar relacionada à expressão de genes envolvidos no reparo do DNA, sendo que a inibição dos mecanismos de reparo do DNA é capaz de aumentar a resposta a TMZ, sobrepujando a resistência inicial observada (GOELLNER, 2011). De fato, o silenciamento epigenético da enzima de reparo de DNA MGMT é o mais forte 
marcador prognóstico preditivo nos pacientes tratados com TMZ (FUKUSHIMA; TAKESHIMA; KATAOKA, 2009). Assim, a Ang II ao promover a expressão de genes envolvidos nos processos biológicos de reparo do DNA poderia aumentar a resistência a drogas alquilantes tais como o TMZ e, portanto, reduzir a possibilidade de eficácia dessa classe de medicamentos.

A identificação em KEGG de genes diferencialmente expressos envolvidos no tema "Doença de Parkinson" no intervalo de 6 horas de tratamento com Ang II indica que o transcriptoma regulado pela Ang II pode também estar relacionado a mecanismos deficientes na neuroproteção. Os genes hipoexpressos pela Ang II nesse tema codificam proteínas dos sistemas citocromo c oxidase e NADH desidrogenase, ambos os sistemas relacionados à fisiologia mitocondrial. A partir da hipoexpressão desses genes, a Ang II poderia causar a disfunção mitocondrial nos astrócitos, aumentando a quantidade de espécies reativas de oxigênio e contribuindo para a morte celular. Como os astrócitos são responsáveis pela nutrição e proteção de neurônios dopaminérgicos, a morte desses astrócitos promoveria a morte subsequente de neurônios dopaminérgicos (MERTENS, 2010).

Além da regulação da transcrição, a fosforilação e o transporte de proteínas foram temas que apresentaram grande quantidade de genes hiperexpressos no intervalo de $6 \mathrm{~h}$ de tratamento com a Ang II. Pode-se inferir a partir dessa observação que a Ang II poderia modificar a localização e a atividade de proteínas na célula tumoral. Como a fosforilação de proteínas é o principal mecanismo envolvido na transdução de sinal, provavelmente os genes pertencentes a esses temas apresentem função importante nos mecanismos moleculares decorrentes da ação da Ang II em gliomas. Alguns exemplos de genes hiper-regulados pela ação da Ang II são citados a seguir. Map4k3, por exemplo, é capaz de induzir a ativação de mTORC1, sendo que um mutante de Drosophila para Map4k3 apresentou crescimento retardado e atividade reduzida de mTORC1 (YAN et al., 2010). A família das cinases da qual a SGK1 pertence apresenta alta homologia com a família das cinases AKT, apresentando similares ativadores a jusante e a montante. As SGKs foram implicadas na regulação do crescimento, proliferação, sobrevivência e migração, processos desregulados em câncer. Ademais, as SGKs são ativadas pela sinalização de PI3K e interagem em vários níveis com a sinalização Ras/Raf/Erk (BRUHN et al., 2010). Tbk1, por outro lado, ativa Akt por fosforilação direta (XIE et 
al., 2011), além de mediar um crosstalk entre a resposta imune inata e a autofagia e também ser um mediador de angiogênese (CZABANKA et al., 2008). Ademais, TBK1 participa de vias de sinalização que têm impacto na transformação celular e progressão tumoral (CLEMENT; MELOCHE; SERVANT, 2008). Mst4, por fim, media - crescimento celular e a transformação maligna pela modulação de Erk independente de Ras/Raf (LIN et al., 2001). A atividade desta cinase (MST4) é estimulada significativamente pelos ligantes do receptor do fator de crescimento epidermal (EGFR), o qual promove o crescimento de células de câncer de próstata (SUNG et al., 2003).

A hiper-representação dos temas "organização do citoesqueleto" e "migração celular", por sua vez, ressalta a característica dos gliomas de disseminação pelo cérebro, sendo que determinantes celulares da migração incluem, por exemplo, a reestruturação do citoesqueleto de actina. Assim, a Ang II ao induzir a hiperexpressão de proteínas associadas à organização do citoesqueleto de actina tais como Mapk1, Arfgap1, Pdgfc e Kras poderiam favorecer a motilidade e invasão dessas células, conferindo um maior grau de malignidade para esses tumores.

Um dos temas mais hiper-representados em KEGG nos intervalos de 3 e 6 horas de tratamento com Ang II foi o da via de sinalização das MAP cinases. Essa via apresenta papel relevante na migração e proliferação celular de GBMs (ZOHRABIAN et al., 2009), sendo que a proposição de inibidores dessa via para combater tumores é corrente (CHAPPELL et al., 2011). Dessa maneira, a hiperexpressão de genes relacionados a essa via pode favorecer o comportamento invasivo dos gliomas. Nessa linha de raciocínio, outras vias de sinalização que favoreçam a ativação das MAP cinases podem também favorecer o comportamento invasivo dos gliomas. Assim, a Ang II ao reduzir a expressão de genes associados à via de mTOR pode ativar a via das MAP cinases, pois a inibição de mTOR está associada a uma hiperativação da via das MAP cinases (ALBERT et al., 2009).

A via de sinalização de PPAR também apresentou genes hipoexpressos pela ação da Ang II. Agonistas dessa via de sinalização apresentam efeitos antineoplásicos em linhagens celulares de gliomas e modelos animais (GROMMES et al., 2010). Portanto, a Ang II ao modular a expressão de genes associados a via de PPAR poderia impedir os efeitos antitumorais associados a essa via. 
A via de sinalização Notch também foi hiper-representada nessa análise. Essa via contribui para o crescimento e sobrevivência dos GBMs (KANAMORI et al., 2007). Foi também descrito que essa via está desregulada em células tronco presentes em gliomas, levando ao crescimento tumoral a partir da geração ou expansão dessas células. A via de Notch também foi envolvida na resposta à hipóxia e angiogênese, as quais correspondem a características típicas dos GBMs. A inibição dessa via, portanto, é uma estratégia promissora para o futuro desenvolvimento de terapias para GBMs (LINO et al., 2010).

Outro tema hiper-representado foi o da via de sinalização da insulina. A insulina é um alvo interessante no contexto de tumores por a transdução de sinal induzida por essa proteína ou por IGFs (insulin-like growth factors) permite tanto a regulação da proliferação celular como a modulação da glicogênese, dois eventos importantes durante a progressão dos tumores. (TROJAN et al., 2007).

As análises de interatoma a partir das comparações Ang $x$ Controle nos intervalos de 3 e 6 horas revelaram hubs que foram selecionados para discussão posterior. Kras e Grb2, por exemplo, participam da via de sinalização associada à Raf e estão associados respectivamente a indução e comportamento maligno de gliomas em modelos animais (LYUSTIKMAN et al., 2008; PRIGENT et al., 1996). Gja1, por sua vez, é capaz de regular o fenótipo indiferenciado de células-tronco em glioma (YU et al., 2012). Já Akt1 possui papel bem descrito na sobrevivência e crescimento celular.

Calm2 media a sinalização de cálcio em diferentes sistemas biológicos. Sua hiperexpressão foi relatada em linfomas, sugerindo que essa sinalização intracelular pode estar associada à oncogênese desses tumores. Já Gipc1 e Ywhah são proteínas adaptadoras envolvidas na interação e regulação de vias de sinalização. Esta última proteína apresenta deleções homozigóticas identificadas em GBMs (SENG et al., 2005).

Mapk1 é parte da via das MAP cinases, importante via de sinalização relacionada à proliferação de tumores (GLASSMANN et al., 2011). Cdk5, por sua vez, media a migração induzida por fatores de crescimento em células de glioma (LIU et al., 2008). Já Sumo1 inibe a migração dessas células (WANG et al., 2010). 


\subsection{Análise funcional do transcriptoma regulado pelo receptor AT1 de Ang II}

De acordo com o descrito na seção de Resultados, os processos biológicos e vias de sinalizações mais relevantes encontrados nas comparações Ang+Los x Ang foram: ciclo celular, mitose, divisão celular, transporte de proteínas, ubiquitinação de proteínas, regulação do crescimento celular, vias metabólicas, replicação e reparo do DNA, diferenciação celular, migração celular, regulação do citoesqueleto de actina, adesão focal, processamento de proteínas no retículo endoplasmático, via de sinalização de p53, regulação da apoptose, vias de sinalização de MAP cinases, PPAR, mTOR e das quimiocinas.

Genes envolvidos com divisão celular, mitose e ciclo celular foram encontrados hipoexpressos no grupo pré-tratado com Losartan, sugerindo que 0 bloqueio do receptor AT1 é capaz de inibir a expressão desses genes. Alguns desses genes inclusive já foram relacionados como marcadores de prognóstico ou associados a biologia de gliomas tais como Cdc25b (NAKABAYASHI; HARA; SHIMIZU, 2006) e Chek2 (SIMON et al., 2006).

A sinalização da adesão focal, tema hiper-representado nesse estudo por genes hipoexpressos como Itga6, Bcar1 e Vegfa já foi descrita em glioblastomas (NATARAJAN, 2003). A adesão das células à matriz extracelular (ECM) por meio das adesões focais é um passo-chave durante sua migração através dos tecidos. Essa sinalização pode agir em glioblastomas como um alvo a jusante da sinalização de fatores de crescimento e integrinas, levando por fim a progressão do ciclo e migração celular (RIEMENSCHNEIDER et al., 2005). Assim, o efeito do Losartan em reduzir a expressão de genes associados à adesão focal é um mecanismo interessante que deve ser estudado em trabalhos futuros.

A hiper-representação do tema "migração celular" ocorreu a partir dos genes Bcar1, Kctd13, Gsk3a e Bambi. Bcar1 é uma proteína envolvida com migração celular que já foi descrita por sua participação na migração de células de gliomas dependentes de fatores de crescimento (EVANS et al., 2011). Também foi demonstrado que a sinalização decorrente da ativação de receptores de integrinas nas adesões focais é dependente dessa proteína e que essa sinalização promove a proliferação celular de astrocitomas (WANG et al., 2000). 
As análises de interatoma a partir das comparações Ang+Los $x$ Ang demonstraram os hubs mais relevantes associados a essas redes. Alguns desses hubs são discutidos a seguir. Tp53 é um gene supressor de tumor cuja via de sinalização apresenta mutação em $87 \%$ dos gliomas (YIN; VAN MEIR, 2009). Já Myc regula a proliferação e sobrevivência de células-tronco em gliomas (WANG et al., 2008). Sdc2, por sua vez, influencia a sensibilidade de GBMs à quimioterapia com semustina (ZHAO et al., 2011).

Ngfr é um fator de crescimento que regula o crescimento, diferenciação e apoptose no sistema nervoso, e possui expressão em astrocitomas humanos (ASSIMAKOPOULOU et al., 2007). Irs1, por sua vez, transmite o sinal dos receptores de insulina para as vias de PI3K e MAP cinases, induzindo a proliferação celular. Por fim, Dlg4 participa da família de proteínas Dlg (Discs-large), às quais estão relacionadas à migração celular (O’NEILL et al., 2011).

\subsection{Análise funcional do transcriptoma regulado pelo receptor AT2}

Conforme visto na seção anterior, os principais temas hiper-representados a partir das comparações entre os grupos Ang + PD x Ang foram: regulação da transcrição, diferenciação celular, regulação da apoptose e da proliferação celular, adesão celular, angiogênese, metabolismo de purinas, adesão focal, regulação do citoesqueleto de actina, vias em câncer, fosforilação e transporte de proteínas, ciclo celular, desenvolvimento do cérebro, resposta inflamatória. Ademais, as vias de sinalização hiper-representadas em KEGG foram ErbB, MAP cinases, mTOR e via de sinalização das neurotrofinas.

Temas envolvidos com a apoptose e via de p53 foram hiper-representados pela ação da Ang II em gliomas via AT2. Assim, pode-se sugerir que o receptor AT2 possui função pró-apoptótica tal como discutido por Arrieta et al. (2008). Entretanto, a hiper-representação de temas associados a ciclo celular e proliferação indica um papel dúbio para esse receptor, o qual deve ser explorado em futuros estudos.

O achado da hiper-representação das vias de sinalização de mTOR e ErbB realçou a importância dessas vias de sinalização e a possível participação de AT2 na modulação dessas vias. Foi demonstrado que mTOR é capaz de exercer um papel importante na tumorigênese e no controle do ciclo celular (NAKAMURA et al., 
2008). De fato, essa via de sinalização tem sido estudada para a terapia alvo específica de gliomas (FAN; WEISS, 2010), sendo que a relação entre mTOR e ErbB também tem sido avaliada (FAN et al., 2009). ErbB, por sua vez, é também alvo corrente em muitos estudos associados a gliomas de alto grau, pois essa sinalização desencadeada por fatores de crescimento promove a proliferação, antiapoptose e migração celular (BEREZOWSKA et al., 2011)

Por fim, a hiper-representação da via de sinalização de neurotrofinas a partir do tratamento com PD123319 corrobora as evidências crescentes relativas da expressão de receptores de neurotrofinas na patogênese da astrocitomas (ASSIMAKOPOULOU et al., 2007).

A análise dos interatomas obtidos a partir das comparações Ang+PD x Ang revelou alguns hubs importantes tais como Prkca, Itgb1, Sumo3, Stxbp1 e Homer1. Prkca é uma cinase envolvida na migração de células C6 (HU et al., 2010). Itgb1 também está associada à adesão celular e difusão de células tumorais (EDWARDS et al., 2011).Já Sumo3 está implicada na gênese da doença mieloproliferativa transiente (HAEMMERLING et al., 2012). Interessantemente, Sumo3 está associada a diversos genes hipoexpressos nessa rede, por exemplo, Hspa8, Arf2m Nup93, Myh9 e Msn. Stxbp1, por sua vez, é co-purificada com a cinase cdc2-like (envolvida no ciclo celular) e está expressa em gliomas (KALIDA et al., 2000). Por fim, Homer1 é uma proteína adaptadora associada a sinalização promovida pelos receptores glutamatérgicos, sendo que sua expressão foi associada ao feocromocitoma maligno (SUH et al., 2009).

\subsection{Similaridades e diferenças dos papéis dos receptores AT1 e AT2}

A partir das análises realizadas por diagramas de Venn, foi possível identificar quais genes são regulados pela Ang II via receptor AT1 e/ou AT2. De maneira geral, muitas similaridades foram observadas entre os genes diferencialmente expressos regulados pelos receptores AT1 e AT2. Temas comuns categorizados em GO e KEGG foram: proliferação celular, apoptose, transporte, migração celular, vias de sinalização de ErbB, mTOR, Insulina, quimiocinas, Hedgehog, Wnt, regulação do citoesqueleto de actina, leucemia, câncer de tireoide, lisossomos e ritmo circadiano. 
Em contrapartida, alguns temas específicos hiper-representados pelos genes diferencialmente expressos regulados pelo receptor AT1 foram: ubiquitinação de proteínas, processamento de RNA e reabsorção de água regulada pela vasopressina. O receptor AT2, por sua vez, modulou a expressão de genes associados a temas específicos como via de sinalização de MAP cinases, processamento de proteínas no retículo endoplasmático, transporte de RNA, junções apertadas e peroxissomos. Assim, das similaridades e diferenças observadas entre os genes diferencialmente expressos regulados por esses receptores, pode-se concluir que ambos os receptores da Ang II regulam genes associados a funções biológicas pró-tumorais, sendo que ambos podem ser complementares em suas funções de induzir um fenótipo maligno em gliomas. Nesse sentido, considerando o ponto de vista evolutivo da célula tumoral, a visão fisiológica antagônica descrita para os receptores AT1 e AT2 não se aplicaria, pois a célula tumoral cooptaria a partir de mutações e alterações genéticas progressivas o receptor AT2 para a realização de funções também pró-tumorais.

\subsection{Análise integrada da Ang II sobre o transcriptoma das células C6}

A abordagem sistemática para o estudo da biologia tem sido cada vez mais corrente na literatura, pois permite a análise global das funções de um determinado agonista em detrimento da análise específica de uma função no contexto tumoral. Nesse trabalho, os diferentes tratamentos realizados permitiram identificar que ambos os receptores da Ang II podem apresentar importantes funções pró-tumorais em gliomas. A observação de que ambos os receptores regulam genes envolvidos em temas funcionais tais como proliferação celular, regulação da apoptose, regulação do ciclo celular, mitose, migração celular, resposta inflamatória, metabolismo celular, entre outros, sugere que o mecanismo de ação da Ang II em gliomas possui a participação de genes envolvidos em diferentes processos celulares.

Notavelmente, a observação de que genes envolvidos nas cascatas de sinalização de PTEN/PI3K/Akt/mTOR e Ras/Raf/MEK/ERK foram regulados pela Ang II e seus receptores condiz com a literatura sobre o tema, em que essas 
sinalizações emergem como principais alvos terapêuticos a serem estudados (LEFRANC et al., 2009).

A maior parte dos genes diferencialmente expressos encontrados aqui apresentou expressão relativa aumentada ou diminuída na faixa entre 1,2 e 3. Esses resultados estão de acordo com o observado em outro trabalho utilizando uma linhagem de câncer de mama (RODRIGUES-FERREIRA et al., 2012), no qual foi mostrado que a Ang II estimula uma resposta fraca e ampla no transcriptoma de células tumorais de mama em detrimento de uma ativação forte de um grupo restrito de genes. Essa observação ressalta que talvez a Ang II regule a expressão de genes associados à regulação da transcrição, tema hiper-representado em algumas das comparações realizadas nesse trabalho. Os autores desse trabalho com câncer de mama também demonstraram que a Ang II modula a expressão de genes envolvidos na proliferação celular, apoptose, adesão celular e migração, inflamação, sinalização de GTPase, sinalização de MAP cinases e vias metabólica, representando uma convergência entre os resultados desses autores e do presente trabalho.

Outro estudo avaliou a contribuição da Ang II e do receptor AT1 na atividade transcricional de células de câncer de próstata (TAKAHASHI et al., 2012). Esse estudo encontrou que bloqueadores do receptor AT1 atenuaram o crescimento do câncer de próstata por meio da inibição de genes associados à via das MAP cinases e também a partir da ativação de genes associados a apoptose. Esses resultados também estão de acordo com os resultados do presente trabalho, pois a via das MAP cinases foi também uma das principais vias hiper-representadas neste projeto.

Apesar dos resultados comuns observados entre nosso trabalho e os dois últimos estudos descritos, mudanças na expressão gênica específicas a gliomas também foram observadas. A hiper-representação de vias de sinalização como ErbB, Akt/mTOR e Notch revela a especificidade do sinal induzido pela Ang II dependendo do tipo celular testado.

Análises utilizando diagramas de Venn auxiliaram a identificar os genes comuns e exclusivos dentre as comparações realizadas. Foi observado que a maior parte dos genes diferencialmente expressos encontrados apresentaram expressão gênica diferencial transiente, refletindo a complexidade do sinal promovido pela Ang II. Nesse contexto, estudos funcionais utilizando os genes comuns encontrados nos 
intervalos de 3 e 6 horas devem ser realizados com o intuito de se avaliar os efeitos pró-tumorais decorrentes do transcriptoma diferencial persistente ao longo do tempo. Também, a partir da análise utilizando diagramas de Venn, foi possível detectar genes regulados pela Ang II por meio do receptor AT1 e por meio do receptor AT2, de maneira que as funções dos genes regulados por esses receptores foram identificadas.

A análise dos interatomas nas diferentes comparações realizadas revelou os principais nós de cada rede, sendo que algumas destas proteínas já foram descritas por seu papel na proliferação, migração, angiogênese e invasão de gliomas. Interessantemente, nos interatomas oriundos da comparação Ang x Control a maior parte dos genes cujas proteínas estão representadas se encontram hiperexpressos, enquanto que nas comparações envolvendo a utilização dos antagonistas de AT1 e AT2, a maior parte das proteínas encontra-se hipo-expressas, demonstrando a capacidade de inibição da expressão gênica dos antagonistas Losartan e PD1223319.

A análise dessas redes biológicas e sua topologia representa uma ferramenta poderosa para a compreensão das respostas biológicas (SHARAN et al., 2006; SOMEREN et al., 2012), pois trata-se uma maneira de simplificar e abstrair os modelos estudados. Para se avaliar a arquitetura de uma rede biológica e sua capacidade de resposta a estímulos, experimentos devem deliberadamente perturbar o modelo estudado. Isso é necessário para se identificar se quando o tumor é interrogado por um estímulo extracelular como a Ang II, os genes e processos biológicos consequentemente ativados podem apresentar função para a evolução do tumor (IRISH et al., 2004). Nesse sentido, experimentos complementares devem ser realizados para confirmar os resultados in vitro e in silico obtidos nesse trabalho. Diferentes períodos de tratamento com a Ang II e seus antagonistas podem confirmar os resultados obtidos nesse trabalho. Além disso, esses resultados poderiam alimentar os interatomas gerados, permitindo um melhor entendimento das redes de proteínas moduladas pela Ang II. Assim, a abordagem utilizada neste trabalho contribuiu para o aumento do conhecimento sobre as ações da Ang II em gliomas e forneceu resultados iniciais para investigações subsequentes nessa relevante linha de pesquisa. 


\section{CONCLUSÕES}

- No modelo experimental estudado os receptores AT1 e AT2, quando ativados pela Ang II nos intervalos de 3 e 6 horas, foram capazes de modular a expressão de genes participantes de processos biológicos e vias de sinalização relacionados a progressão de gliomas, tais como ciclo celular, mitose, crescimento, invasão e migração celular, regulação de citoesqueleto de actina, entre outros;

- as similaridades e diferenças observadas entre os genes diferencialmente expressos regulados pelos receptores AT1 e AT2, revelam que ambos os receptores são complementares em suas funções de induzir um fenótipo maligno em gliomas. Nesse caso, a visão fisiológica antagônica dos receptores AT1 e AT2 não se aplica, pois a célula tumoral coopta a partir de mutações e alterações genéticas progressivas, ambos os receptores para a realização de funções pró-tumorais;

- a expressão diferencial de genes envolvidos nas vias de sinalização Ras/Raf/Erk e $\mathrm{PI}$ 3K/AKT/mTOR corrobora a relevância dessas vias em GBMs e sugere que a Ang II por meio da ativação dos receptores AT1 e AT2 pode potencializar o efeito de fatores de crescimento como EGF e PDGF na proliferação, migração, invasão, angiogênese e outros processos relevantes para o desenvolvimento do tumor;

- foram encontradas outras vias de sinalização com genes modulados pela Ang II ou pelos antagonistas dos receptores AT1 e AT2: Notch, VEGF, neurotrofinas, insulina, TGF- $\beta$, e p53. Isso sugere que a Ang II apresenta mecanismo de ação que envolve múltiplas vias de sinalização em gliomas;

- as análises dos diagramas de Venn sugerem que a maioria das alterações de expressão gênica encontradas foram transientes. Estudos funcionais com os genes que apresentaram mudanças duradouras na expressão gênica devem ser realizados com o intuito de se verificar possíveis funções pró-tumorais desses genes;

- as análises dos interatomas permitiram identificar hubs com funções centrais em suas respectivas redes. Esses genes devem ser posteriormente estudados em detalhe para avaliar de que maneira a Ang II regula os mesmos e qual o resultado fenotípico da modulação da expressão gênica desses alvos. 


\section{PERSPECTIVAS DE TRABALHO}

- Estabelecer um modelo in vitro de gliomas que hiperexpresse os receptores AT1 e AT2;

- realizar análises temporais de expressão gênica no modelo do item anterior para verificar como as redes associadas aos genes diferencialmente expressos se comportam;

- estudar o efeito dos antagonistas dos receptores de Ang II e também de inibidores de vias de sinalização identificadas nas análises de DNA microarray em ensaios in vitro de proliferação, migração, invasão e/ou angiogênese utilizando o modelo de hiperexpressão de AT1 e AT2;

- investigar o efeito dos antagonistas dos receptores de Ang II e também de inibidores de vias de sinalização identificadas nas análises de DNA microarray em modelo experimentais in vivo de glioma;

- avaliar os genes diferencialmente expressos entre GBMs humanos com alta e baixa expressão dos receptores AT1 e AT2;

- estudar em gliomas humanos possíveis mutações, amplificações e variações no número de cópias dos receptores AT1 e AT2 que ocasionem a hiperexpressão desses receptores em um subgrupo de GBMs humanos. 


\section{REFERÊNCIAS*}

ALBERT, L. et al. Inhibition of mTOR activates the MAPK Pathway in Glioblastoma Multiforme. Cancer Genomics Proteomics, v. 6, n. 5, p. 255-261, 2009.

ARRIETA, O. et al. Blockage of angiotensin II type I receptor decreases the synthesis of growth factors and induces apoptosis in C6 cultured cells and C6 rat glioma. British Journal of Cancer, v. 92, n. 7, p. 1247-1252, 2005.

ARRIETA, O. et al. Expression of AT1 and AT2 angiotensin receptors in astrocytomas is associated with poor prognosis. British Journal of Cancer, v. 99, n. 1 p. 160-166, 2008.

ASSIMAKOPOULOU, M. et al. Neurotrophin receptors expression and JNK pathway activation in human astrocytomas. BMC Cancer, v.7, p.202, 2007.

ATEEQ, B.; TOMLINS, S. A.; CHINNAIYAN, A. M. AGTR1 as a therapeutic target in ER-positive and ERBB2-negative breast cancer cases. Cell Cycle, v. 8, n. 23, p. 3794-3795, 2009.

BARTH, R. Rat brain tumors models in experimental neurooncology. The 9L, C6, T9, F98, RG 2, (D 74), RT-2, and CNS-1 gliomas. Journal of Neurooncology, v. 36, p. 91-102, 1998.

BERETTA, F. et al. The GluR2 subunit inhibits proliferation by inactivating Src-MAPK signaling and induces apoptosis by means of caspase $3 / 6$-dependent activation in glioma cells. European Journal of Neuroscience, v. 30, n.1, p. 25-34, 2009.

BEREZOWSKA, S.; SCHLEGEL, J. Targeting ErbB receptors in high-grade glioma. Current Pharmaceutical Design, v. 17, n. 23, p. 2468-2487, 2011.

BIE, L. et al. The accuracy of survival time prediction for patients with glioma is improved by measuring mitotic spindle checkpoint gene expression. Plos One, v. 6, n. 10, p. e25631, 2011.

BROGNARD, J. et al. Cancer-associated loss-of-function mutations implicate DAPK3 as a tumor-suppressing kinase. Cancer Research, v. 71, n. 8, p. 3152-3161, 2011.

BRUHN, M. A.; PEARSON, R. B.; HANNAN, R. D.; SHEPPARD, K. E. Second AKT: the rise of SGK in cancer signaling. Growth Factors, v. 28, n. 6, p. 394-408, 2010.

BUYSSACHERT et al. Genetic, epigenetics and pharmaco-(epi), genomics in angiogenesis. Journal of Cellular and Molecular Medicine, v. 12, p. 2533-2551, 2009.

\footnotetext{
* De acordo com: ASSOCIAÇÃO BRASILEIRA DE NORMAS TÉCNICAS. NBR 6023: informação e documentação: referências: elaboração. Rio de Janeiro, 2002.
} 
CHAPPELL, W. H. et al. Ras/Raf/MEK/ERK and PI3K/PTEN/Akt/mTOR inhibitors: rationale and importance to inhibiting these pathways in human health. Oncotarget, v. 2, n. 3, p.135-164, 2011.

CHAKRAVARTI, A. et al. The prognostic significance of phosphatidylinositol 3-kinase pathway activation in human gliomas. Journal of Clinical Oncology, v. 22, n. 10, p. 1926-1933, 2004.

CHAMBERLAIN, M. C. et al. Early necrosis following concurrent Temodar and radiotherapy in patients with glioblastoma. Journal of Neurooncology, v. 82, n. 1, p. 81-83, 2006.

CHEN, L. et al. $\beta$-catenin/Tcf-4 complex transcriptionally regulates AKT1 in glioma. International Journal of Oncology, v. 39, n. 4, p. 883-890, 2011.

CHIPITSYNA, G. et al. Induction of monocyte chemoattractant protein-1 expression by angiotensin II in the pancreatic islets and beta-cells. Endocrinology, v. 148, n. 5, p. 2198-2208, 2007.

CHITTENDEN, T. W. et al. Therapeutic implications of GIPC1 silencing in cancer. Plos One, v. 5, n. 12, p. e15581, 2010.

CLEMENT, J. F.; MELOCHE, S.; SERVANT, M. J. The IKK-related kinases: from innate immunity to oncogenesis. Cell Research, v. 18, n. 9, p. 889-899, 2008.

CLERE, N. et al. Deficiency or blockade of Angiotensin II type 2 receptor delays tumorigenesis by inhibiting malignant cell proliferation and angiogenesis. International Journal of Cancer, v. 127, n. 10, p. 2279-2291, 2010.

CRETU, A. Human and rat glioma growth, invasion and vascularization in a novel chick embryo brain tumor model. Clinical and Experimental Neurooncology, v. 22, p. 225-236, 2005.

CZABANKA, M. et al. Influence of TBK-1 on tumor angiogenesis and microvascular inflammation. Frontiers in Bioscience, v. 13, p. 7243-7249, 2008.

CZERWENKA, K. F. et al. Comparative analysis of two-dimensional protein patterns in malignant and normal human breast tissue. Cancer Detection and Prevention, v. 25 , n. 3, p. 268-279, 2001.

DA FONSECA, C. O. et al. Recent advances in the molecular genetics of malignant gliomas disclose targets for antitumor agent perillyl alcohol. Surgical Neurology, v. 65, p. S2-S8, 2006.

DEANGELIS, L.M. Brain tumors. New England Journal of Medicine, v. 344, p. 114-123, 2001.

DOMINSKA, K. et al. The involvement of the renin-angiotensin system (RAS) in cancerogenesis. Postepy Biochemii, v. 54, n. 3, p. 294-300, 2008. 
EDWARDS, L. A. et al. Effect of brain- and tumor-derived connective tissue growth factor on glioma invasion. Journal of the National Cancer Institute, v. 103, n. 15, p. 1162-1178, 2011.

ESCOBAR, E. et al. Angiotensin II, cell proliferation and angiogenesis regulator: biologic and therapeutic implications in cancer. Current Vascular Pharmacology, v. 2, n. 4, p. 385-399, 2004.

EVANS, I. M. et al. Neuropilin-1 signaling through p130Cas tyrosine phosphorylation is essential for growth factor-dependent migration of glioma and endothelial cells. Molecular Cell Biology, v. 31, n.6, p.1174-1185, 2011.

FAN, Q. W. et al. EGFR signals to mTOR through PKC and independently of Akt in glioma. Science Signaling, v.2, n.55, p.ra4, 2009.

FAN, Q. W.; WEISS, W. A. Targeting the RTK-PI3K-mTOR axis in malignant glioma: overcoming resistance. Current Topics in Microbiology and Immunology, v. 347, p. 279-296, 2010.

FEIG, L. A.; BAST, R. C.; KNAPP, R. C.; COOPER, G. M. Somatic activation of rasK gene in a human ovarian carcinoma. Science, v. 223, n. 4637, p. 698-701, 1984.

FIGARELLA-BRANGER, D. et al. Classification histologique et moléculaire des gliomes. Histological and molecular classification of Gliomas. Revue Neurologique, v.164, p. 505-515, 2008.

FUKUSHIMA, T.; TAKESHIMA, H.; KATAOKA, H. Anti-glioma therapy with temozolomide and status of the DNA-repair gene MGMT. Anticancer Research, v. 29, n. 11, p. 4845-4854, 2009.

FUJITA, M. et al. Blockade of angiotensin AT1a receptor signaling reduces tumor growth, angiogenesis, and metastasis. Biochemical and Biophysical Research Communications, p. 441-447, 2002.

GLASSMANN, A. et al. Pharmacological targeting of the constitutively activated MEK/MAPK-dependent signaling pathway in glioma cells inhibits cell proliferation and migration. International Journal of Oncology, v. 39, n.6, p.1567-1575, 2011.

GOELLNER, E.M. et al. Overcoming temozolomide resistance in glioblastoma via dual inhibition of NAD+ biosynthesis and base excision repair. Cancer Research, v. 71, n. 6 , p. 2308-2317, 2011.

GROBBEN, B. et al. Rat C6 glioma as experimental model system for the study of glioblastoma growth and invasion. Cell Tissue Research, v. 310, n.3, p. 257-270, 2002.

GROMMES, C. et al. Inverse association of PPARY agonists use and high grade glioma development. Journal of Neurooncology, v. 100, n. 2, p. 233-239, 2010. 
HAEMMERLING S. et al. A $15 q 24$ microdeletion in transient myeloproliferative disease (TMD) and acute megakaryoblastic leukaemia (AMKL) implicates PML and SUMO3 in the leukaemogenesis of TMD/AMKL. British Journal of Haematology, $v$. 157, n. 2, p. 180-187, 2012.

HAQUE, T. et al. Gene expression profiling from formalin-fixed paraffin-embedded tumors of pediatric glioblastoma. Clinical Cancer Research, v. 13, n. 21, p. 62846292, 2007.

HANISCH, A. et al. Timely anaphase onset requires a novel spindle and kinetochore complex comprising Ska1 and Ska2. EMBO Journal, v. 25, n. 23, p. 5504-5515, 2006.

HANSEN, K. et al. Autophagic cell death induced by TrkA receptor activation in human glioblastoma cells. Journal of Neurochemistry, v. 103, n. 1, p. 259-275, 2007.

HEER, R. et al. Fibroblast growth factor 17 is over-expressed in human prostate cancer. Journal of Pathology, v. 204, n. 5, p. 578-586, 2004.

HENRIKSSON, R. et al. Impact of therapy on quality of life, neurocognitive function and their correlates in glioblastoma multiforme: a review. Journal of Neurooncology, v. 104, n. 3, p. 639-646, 2011.

HERR et al. Potencial role of Renin-Angiotensin-system for tumor angiogenesis in receptor negative breast cancer. Gynecologic Oncology, v. 109, p. 418-425, 2008.

HOLLAND, J. T. et al. Targeting brain cancer: advances in the molecular pathology of malignant glioma and medulloblastoma. Nature Reviews Cancer, v.10, p. 319331, 2010.

HORIUCHI, M. et al. Crosstalk between angiotensin II type 1 and type 2 receptors: cellular mechanism of angiotensin type 2 receptor-mediated cell growth inhibition. Hypertension Research, v.22, n.2, p. 67-74, 1999.

$\mathrm{HU}, \mathrm{J}$. G. et al. Activation of PKC-alpha is required for migration of C6 glioma cells. Acta Neurobiologiae Expimentalis, v. 70, n. 3, p. 239-245, 2010.

HUI, A. B. et al. Detection of multiple gene amplifications in glioblastoma multiforme using array-based comparative genomic hybridization. Laboratory Investigation, v. 81, n. 5, p. 717-723, 2001.

IDEKER, T.; KROGAN, N. J. Differential network biology. Molecular System Biology, v. 8, p. 565, 2012.

IRISH, J. M. Single cell profiling of potentiated phospho-protein networks in cancer cells. Cell, v. 118, n. 2, p. 217-228, 2004.

KANAMORI, M. et al. Contribution of Notch signaling activation to human glioblastoma multiforme. Journal of Neurosurgery. v. 106, n. 3, p. 417-427, 2007. 
KASCHINA, E.; UNGER, T. Angiotensin AT1/AT2 receptors: regulation, signalling and function. Blood Pressure, p. 70-88, 2003.

KLEIHUES, P. et al. The WHO classification of tumors of the nervous system. Journal of Neuropathology and Experimental Neurology, v. 61, p. 215-225, 2002.

KNOBBE, C. B.; REIFENBERGER, G. Genetic alterations and aberrant expression of genes related to the phosphatidyl-inositol-3'-kinase/protein kinase B (Akt) signal transduction pathway in glioblastomas. Brain Pathology, v. 13, n. 4, p. 507-518, 2003.

LEFRANC, F. et al. Present and potential future adjuvant issues in high-grade astrocytic glioma treatment. Advances and Technical Standards in Neurosurgery, v. 34, p. 3-35, 2009.

LESNIAK, M.S. et al. Local delivery of doxorubicin for treatment of malignant brain tumors in rats. Anticancer Research, v. 25, n. 6, p. 3825-3831, 2005.

LI, X. C.; ZHUO, J. L. Intracellular ANG II directly induces in vitro transcription of TGF-beta1, MCP-1, and NHE-3 mRNAs in isolated rat renal cortical nuclei via activation of nuclear AT1a receptors. American Journal of Physiology. Cell Physiology, v. 294, n. 4, p. 1034-1045, 2008.

LIN, J. L. et al. MST4, a new Ste20-related kinase that mediates cell growth and transformation via modulating ERK pathway. Oncogene, v. 20, n. 45, p. 6559-6569, 2001.

LINO, M. M. et al. Notch signaling in glioblastoma: a developmental drug target? BMC Medicine, v. 8, p. 72, 2010.

LINO, M. M.; MERLO, A. PI3Kinase signaling in glioblastoma. Journal of Neurooncology, v. 103, n. 3, p. 417-427, 2011.

LIU, R. et al. Cdk5-mediated regulation of the PIKE-A-Akt pathway and glioblastoma cell invasion. Proceedings of the National Academy of Science. 105, v. 21, p. 7570-7575, 2008.

LYUSTIKMAN, Y. et al. Constitutive activation of Raf-1 induces glioma formation in mice. Neoplasia, v. 10, n. 5, p. 501-510, 2008.

MARTIN, A., et al. BisoGenet: a new tool for gene network building, visualization and analysis. BMC Bioinformatics, v. 11, p. 91, 2010.

MAGGIO, W. W. Rodent glioma models. In: PEREZ-POLO, J. R. (Ed.). Methods in neurosciences, paradigms of neural injury, San Diego: Academic Press Inc.; 1996. vol. 30. p. 81-96. 
MARIE et al. Maternal embryonic leucine zipper kinase transcript abundance correlates with malignancy grade in human astrocytomas. International Journal of Cancer, v. 122, p. 807-815, 2008.

MENG et al. 9L Gliosarcoma cell proliferation and tumor growth in rats are suppressed by N-Hydroxy-N-(4-butyl-2-methylphenol). Foramadine (HET0016) a selective inhibitor of CYP4A. The Journal of Pharmacology and Experimental Therapeutics, v. 317, p. 97-111, 2006.

MERTENS, B. et al. The role of the central renin-angiotensin system in Parkinson's disease. Journal of the Renin Angiotensin Aldosterone System, v. 11, n. 1, p. 4956, 2010.

MISCHEL, P.S. et al. Molecular analysis of glioblastoma: pathway profiling and its implications for patient therapy. Cancer Biology \& Therapy. v. 2, n. 3, p. 242-247, 2003.

MIURA, S. et al. Molecular mechanisms of the antagonistic action between. Biochemical and Biophysical Research Communications, v. 391, n.1, p. 85-90, 2010.

MOLINA-PINELO, S. et al. Down-regulation of spinophilin in lung tumours contributes to tumorigenesis. Journal of Pathology, v. 225, n. 1, p. 73-82, 2011.

NAKAMURA, J. L. et al. S6K1 plays a key role in glial transformation. Cancer Research, v. 68, n. 16, p. 6516-6523, 2008.

NAGER, M. et al. $\beta$-Catenin Signalling in Glioblastoma Multiforme and GliomaInitiating Cells. Chemotherapy Research and Practice, p. e192362, 2012.

NAKABAYASHI, H.; HARA, M.; SHIMIZU, K. Prognostic significance of CDC25B expression in gliomas. Journal of Clinical Pathology. v. 59, n. 7, p. 725-728, 2006.

NATARAJAN, M. et al. FAK signaling in anaplastic astrocytoma and glioblastoma tumors. Cancer Journal, v. 9, n. 2, p. 126-33, 2003.

OLIVEIRA et al. Contribution of gap junctional communication between tumor cells and astroglia to the invasion of the parenchyma by human glioblastomas. BioMed Central, v. 6, p. 1-17, 2005.

O'NEILL A. K. et al. Protein kinase Ca promotes cell migration through a PDZdependent interaction with its novel substrate discs large homolog 1 (DLG1). Journal of Biological Chemistry, v. 286, n. 50, p. 43559-43568, 2011.

PERRY, A. Pathology of low-grade gliomas: an update of emerging concepts. Neuro Oncology, v. 5, n. 3, p. 168-178, 2003.

PRIGENT, S. A. Enhanced tumorigenic behavior of glioblastoma cells expressing a truncated epidermal growth factor receptor is mediated through the Ras-Shc-Grb2 pathway. Journal of Biological Chemistry, v. 271, n. 41, p. 25639-25645, 1996. 
RHODES, D.R. et al. AGTR1 overexpression defines a subset of breast cancer and confers sensitivity to Losartan, an AGTR1 antagonist. Proceedings of the National Academy of Sciences, v.106, n. 25, p. 10284-10289, 2009.

RICKMAN, D.S. et al. Distinctive molecular profiles of high-grade and low-grade gliomas based on oligonucleotide microarray analysis. Cancer Research, v. 61, n. 18, p. 6885-6891, 2001.

RIEMENSCHNEIDER, M. J. et al. In situ analysis of integrin and growth factor receptor signaling pathways in human glioblastomas suggests overlapping relationships with focal adhesion kinase activation. American Journal of Pathology, v. 167, n. 5, p. 1379-1387, 2005.

RIVERA, E. et al. AT1 receptor is present in glioma cells; its blockage reduces the growth of rat glioma. British Journal of Cancer, v. 85, n. 9, p.1396-1399, 2001.

RODRIGUES-FERREIRA, S. et al. Angiotensin II facilitates breast cancer cell migration and metastasis. Plos One, v. 7, n. 4, p. e35667, 2012.

RUST, R. et al. High expression of calcium-binding proteins, S100A10, S100A11 and CALM2 in anaplastic large cell lymphoma. British Journal of Hematology, v. 131, n. 5, p. 596-608, 2005.

SCHROEDER, A. et al. The RIN: an RNA integrity number for assigning integrity values to RNA measurements. BMC Molecular Biology, v. 7, n. 3, 2006.

SCRIDELI, C. A. et al. Gene expression profile analysis of primary glioblastomas and non-neoplastic brain tissue: identification of potential target genes by oligonucleotide microarray and real-time quantitative PCR. Journal of Neurooncology, v. 88, p. 281-291, 2008.

SHARAN, R.; IDEKER, T. Modeling cellular machinery through biological network comparison. Nature Biotechnology, v. 24, p. 427-433, 2006.

SIBENALIER Z. A. et al. Genetic Characterization of Commonly Used Glioma Cell Lines in the Rat Animal Model System. Neurosurgical Focus, v. 19, n.4, p. E1, 2005.

SIMON, M. et al. Variant of the CHEK2 gene as a prognostic marker in glioblastoma multiforme. Neurosurgery, v. 59, n. 5, p. 1078-1085, 2006.

SOUSA, P. et al. Gliomas del tronco encefálico. Neurocirurgía, v. 15, p. 56-66,2004. STUPP, R. et al. Radiotherapy plus concomitant and adjuvant temozolomide for glioblastoma. New England Journal of Medicine, v. 352, p. 987-996, 2005.

STUPP, R. et al. Effects of radiotherapy with concomitant and adjuvant temozolomide versus radiotherapy alone on survival in glioblastoma in a randomised phase III study: 5-year analysis of the EORTC-NCIC trial. Lancet Oncology, v. 10, p. 459-466, 2009. 
SUH, I. et al. Candidate genes associated with malignant pheochromocytomas by genome-wide expression profiling. Annals of Surgery, v. 250, n. 6, p. 983-990, 2009.

SUNG, V. et al. The Ste20 kinase MST4 plays a role in prostate cancer progression. Cancer Research, v. 63, n. 12, p. 3356-3363, 2003.

SUZUKI, T. et al. Genetic analysis of human glioblastomas using a genomic microarray system. Brain Tumor Pathology, v. 21, n. 1, p. 27-34, 2004.

TAKAHASHI, S. et al. Therapeutic targeting of angiotensin II receptor type 1 to regulate androgen receptor in prostate cancer. Prostate, v. 72, n. 14, p. 1559-1572, 2012.

TROJAN, J. et al. Insulin-like growth factor type I biology and targeting in malignant gliomas. Neuroscience, v. 145, n. 3, p. 795-811, 2007.

VALERA, E. T. et al. Pediatric glioblastoma cell line shows different patterns of expression of transmembrane $A B C$ transporters after in vitro exposure to vinblastine. Children Nervous System, v. 25, p. 39-45, 2009.

VAN SOMEREN, E. P. et al. Genetic network modeling. Pharmacogenomics, v. 3, p. 507-525, 2002.

VOLKNANDT, W. et al. Expression and allocation of proteins of the exo-endocytotic machinery in U373 glioma cells: similarities to long-term cultured astrocytes. Cellular and Molecular Neurobiology, v. 22, n. 2, p. 153-169, 2002.

WANG, Y. et al. Trk A, B, and C are commonly expressed in human astrocytes and astrocytic gliomas but not by human oligodendrocytes and oligodendroglioma. Acta Neuropathologica, v. 96, n. 4, p. 357-364, 1998.

WANG, D. et al. p125 focal adhesion kinase promotes malignant astrocytoma cell proliferation in vivo. Journal of Cell Science, v. 23, p. 4221-4230, 2000.

WANG, J. et al. c-Myc is required for maintenance of glioma cancer stem cells. Plos One, v. 3, n. 11, p. e3769, 2008.

WANG, Y. et al. Icariin exterts negative effects on human gastric cancer cell invasion and migration by vasodilator-stimulated phosphoprotein via Rac1 pathway. European Journal of Pharmacology, v. 635, n. 3, p. 40-48, 2010.

WASCH, R.; ENGELBERT, D. Anaphase-promoting complex-dependent proteolysis of cell cycle regulators and genomic instability of cancer cells. Oncogene, v. 24, n. 1, p. 1-10, 2005.

WESSELS, P. H. et al. 10q25.3 (DMT1) Copy number changes in astrocytoma grades II and IV. Genes, Chromosomes \& Cancer, v. 39, p. 22-28, 2004. 
WHITTLE, I. R. et al. Can experimental models of rodents implantation glioma be improved? A study of pure and mixed glioma cells line tumours. Journal of Neurooncology, v. 36, p. 231-242, 1998.

WONG, M. L. et al. Targeting malignant glioma survival signaling to improve clinical outcomes. Journal of Clinical Neuroscience, v. 14, p. 301-308, 2007.

WROBEL, G. et al. Microarray-based gene expression profiling of benign, atypical and anaplastic meningiomas identifies novel genes associated with meningioma progression. International Journal of Cancer, v. 114, n. 2, p. 249-256, 2005.

XIE, X. et al. IkappaB kinase epsilon and TANK-binding kinase 1 activate AKT by direct phosphorylation. Proceedings of the National Academy of Science, v. 108, n. 16, p. 6474-6479, 2011.

YEH, W.L. et al. Leptin induces migration and invasion of glioma cells through MMP13 production. Glia, v. 57, n. 4, p. 454-64, 2009.

YIN, L. et al. The mechanisms on apoptosis by inhibiting VEGF expression in human breast cancer cells. International Immunopharmacology, v. 9, p. 389-395, 2009.

YAMADA, T. et al. "Angiotensin II type 2 receptor mediates programmed cell death." Proceedings of the National Academy of Sciences, v. 93, n.1, p. 156-160, 1996.

YAN, L. et al. Nutrient regulation of mTORC1 and cell growth. Cell Cycle, v. 9, n. 13, p. 2473-2474, 2010.

YANG, Y. H. et al. Normalization for cDNA microarray data: a robust composite method addressing single and multiple slide systematic variation. Nucleic Acids Research, v. 30, n. 4, p. e15, 2002.

YIN, S.; VAN MEIR, E. G. p53 pathway alterations in brain tumors. In: VAN MEIR, E. G. (Ed.). CNS cancer: models, markers, prognostic factors, targets and therapeutic approaches. New York: Human Press, 2009. p. 283-314.

YU, S. C. et al. Connexin 43 reverses malignant phenotypes of glioma stem cells by modulating E-cadherin. Stem Cells, v. 30, n. 2, p. 108-120, 2012.

ZHAO, Z. et al. Candidate genes influencing sensitivity and resistance of human glioblastoma to Semustine. Brain Research Bullets, v. 86, n. 3, p.189-194, 2011. ZOHRABIAN, V. M. et al. Rho/ROCK and MAPK signaling pathways are involved in glioblastoma cell migration and proliferation. Anticancer Research, v. 29, n. 1, p. 119-123, 2009. 


\section{APÊNDICES}

\section{APÊNDICE A - Quadros suplementares contendo os genes presentes em cada tema hiper-representado nas comparações realizadas}

\section{Quadro S1 - Genes diferencialmente expressos enriquecidos em KEGG no intervalo de 3 horas de tratamento com Ang II.}

\begin{tabular}{|c|c|}
\hline Categoria - KEGG & Genes hiperexpressos \\
\hline $\begin{array}{l}\text { MAPK signaling } \\
\text { pathway }\end{array}$ & $\begin{array}{c}\text { Mapk1, Cdc25b, Akt1, Kras, Map2k4, Mapkapk2, Mecom, } \\
\text { Map2k5, Ppp3r1, Elk1, Rras, Ppp5c, Gna12 }\end{array}$ \\
\hline Chemokine signaling pathway & Shc3, Mapk1, Akt1, Kras, Cxcl10, Cxcl12, Gnai3, Prex1, Gnb2 \\
\hline Regulation of actin cytoskeleton & Mapk1, Apc, Kras, Myl9, Rras, Fgd1, Pdgfc, Gna12, Git1 \\
\hline Tight junction & Akt1, Kras, Magi3, Gnai3, Myl9, Inadl, Rras, Pard6b, Llgl1 \\
\hline ErbB signaling pathway & Shc3, Mapk1, Akt1, Kras, Map2k4, Elk1, Nck2 \\
\hline Neurotrophin signaling pathway & Shc3, Mapk1, Akt1, Kras, Mapkapk2, Map2k5, Sh2b1 \\
\hline Ubiquitin mediated proteolysis & Keap1, Ube2e3, Pias1, Mgrn1, KIhl13, Anapc10, LOC68922 \\
\hline Insulin signaling pathway & Shc3, Mapk1, Akt1, Kras, Elk1, Rhoq \\
\hline Chronic myeloid leukemia & Shc3, Mapk1, Akt1, Kras, Mecom, E2f1 \\
\hline Cell cycle & Cdc25b, Mcm5, Mcm6, Tfdp2, Anapc10, E2f1 \\
\hline Glioma & Shc3, Mapk1, Akt1, Kras, E2f1 \\
\hline $\begin{array}{l}\text { VEGF signaling pathway } \\
\text { Gap junction }\end{array}$ & $\begin{array}{c}\text { Mapk1, Akt1, Kras, Mapkapk2, Ppp3r1 } \\
\text { Mapk1, Kras, Gnai3, Map2k5, Pdgfc }\end{array}$ \\
\hline Categoria - KEGG & Genes hipoexpressos \\
\hline $\begin{array}{l}\text { Protein processing in } \\
\text { endoplasmic reticulum }\end{array}$ & Stub1, Ganab, Bag1, Tram1, Ckap4, Man1b1, Wfs1 \\
\hline Axon guidance & Sema3c, Nfat5, Efn4, Ephb6, Unc5a, Slit1 \\
\hline ECM-receptor interaction & Lama5, Cd47, Col1a1, Col5a3 \\
\hline TGF-beta signaling pathway & Ep300, Gdf7, Ltbp1, Tgfb2 \\
\hline PPAR signaling pathway & Dbi, Slc27a4, Scd4, Slc27a1 \\
\hline mTOR signaling pathway & Rps6ka2, Ins1, Tsc2 \\
\hline Notch signaling pathway & Ep300, Ncstn, Psen2 \\
\hline $\begin{array}{l}\text { Aldosterone-regulated sodium } \\
\text { reabsorption }\end{array}$ & Ins1, Prkca, Scnn1a \\
\hline $\mathrm{N}$-Glycan biosynthesis & Ganab, Alg11, Man1b1 \\
\hline
\end{tabular}




\section{Quadro S2 - Genes diferencialmente expressos enriquecidos em GO no intervalo de 3 horas de tratamento com Ang II.}

Processo Biológico - GO

cell cycle

cell division

cell growth

protein transport

intracellular signal transduction small GTPase mediated signal transduction

protein folding

protein ubiquitination /

polyubiquitination

actin cytoskeleton organization

MyD88-dependent toll-like

receptor signaling pathway

Wnt receptor signaling pathway

response to DNA damage stimulus

response to ionizing radiation
Genes hiperexpressos

Apc, Ccng1, Nucks1, Rab11b, Sept9, Rgs2, Mapk1, Cdc25b, Cgref1, Mecom, Thap1, Specc1l, Ankrd54, Lzts, E2f1, Pdcd6ip Cdc25b, Ccng1, Gnai3, Specc1l, LZts2, Pdcd6ip, Sept9

Akt1, Cxcl12, Map2k5, Taf9

Nutf2, Sec13, Atp6v1e1, Ipo9, Chchd4, Pex5, Chmp1a, Pdcd6ip, Exoc5, Ykt6, Atp6v1a, Rab11b

Shc3, Mapk1, Akt1, Def8, Dnmbp, PRerx1, Blnk, Grb15,Sh2b1

Mapk1, Kras, Rnd2, Rras, Arl6, Rab11b, Rhoq, Gnai3, Gfm2, Gna12

Fkbp4, Ranbp2, Ppil4, Dnajc11, Ptges3, Grpel1, St13

Akt1, Mgrn1, Klhl13, Rnf187, Zfp364, March2, Ube2e3, Ube2v1, Mgrn1, Rnf187, LOC689226

Kras, Fhl3, Fgd1, Llgl1, Cap1, Rhoq

Mapk1, Map2k4, Mapkapk2, Ube2v1, Elk1

Wif1, Apc, Ldb1, Lzts2

Mapk1, Apc, Apbb1, Paxip1, Obfc2b

Cxcl10, Vcam1, Paxip1, Obfc2b

Processo Biológico - GO

Genes hipoexpressos

ion transport

brain development

protein transport

heart development

negative regulation of cell proliferation

negative regulation of apoptosis

response to hypoxia

axon guidance

protein folding

negative regulation of cell growth cell migration
Steap3, Tmem37, Scnn1a, Kcnh3, Kcnk3, Gabrd, Slc22a18, Cacna1i, Slc22a23, Slc12a6

Ptprg, Dbi, Cdk5rap1, Nkx2-1, Cdk5rap2, Kcnk3, Bcr, Slc7a11, Slit1, Hrh3

Steap3, Aagab, Dnm2, Mcoln1, Cox18, Apoc2, Col1a1, Lca5, Tram1, Psen

Rps6ka2, Sox9, Ep300, Gja1, Tsc2, Oxt, Sema3c, Sox18, Tgfb2

Sox9, Gja1, Grm4, Igfbp3, Prkca, Tsc2, Serpine2, S2f7, Tgfbp2

Sox9, Grm4, Bag1, Cln8, Tex11, Psen2, Tgfb2, Wfs1

Ep300, Pnmt, Tsc2, Kcnk3, Agtrap, Adsl, Psen2, Tgfbp2

Gdf7, Nkx2-1, Neurog2, Unc5a, Slit1, Tgfb2

Ganab, Bag1, RGD1565752, Dnajc17, Fxbp10, Man1b1

Dnajc2, Serpine2, Ndufa13, Slit1, Tgfb2

Lama5, Cd47, Lamb1, Mdk, Tgfb2 


\section{Quadro S3 - Genes diferencialmente expressos enriquecidos em KEGG no intervalo de 6 horas de tratamento com Ang II.}

\begin{tabular}{|c|c|}
\hline Categoria - KEGG & Genes hiperexpressos \\
\hline Cell cycle & $\begin{array}{c}\text { Chek2, Ccna2, Bub1b, Ccnb1, Ywhaq, Skp2, Smc3, Mcm4, Hdac1, } \\
\text { Anapc1, Stag2, Cdc7, MGC112830, Anapc10, Cdk2, Cdc26, } \\
\text { Cdkn2c, Cdkn2d, Cdc20 }\end{array}$ \\
\hline Pathways in cancer & $\begin{array}{l}\text { Mapk1, Smo, Ctbp1, Skp2, Hdac1, Pias1, Stk36, Col4a2, Cdk2, } \\
\text { Tcf7, Mapk9, Ccdc6, Grb2, Mlh2, Sos2, Mmp9 }\end{array}$ \\
\hline RNA transport & $\begin{array}{l}\text { Nup107, Eif4e, Eif4a1, Thoc3, Ncbp1, Pabpc4, Sumo1, } \\
\text { RGD1306195, Nup205, Eif4e2, Gemin7, Sumo2, Thoc4 }\end{array}$ \\
\hline MAPK signaling pathway & $\begin{array}{c}\text { Mapk1, Mapk4k3, Hspa8, Hspa1l, Ntf4, Map2k4, Pak2, Elk1, } \\
\text { Mapk9, Chp, Grb2, Sos2 }\end{array}$ \\
\hline Focal adhesion & $\begin{array}{c}\text { Mapk1, Capn2, Pak2, Vcl, Col4a2, Elk1, Vasp, Itga8, Mapk9, Grb2, } \\
\text { Sos2 }\end{array}$ \\
\hline Insulin signaling pathway & Mapk1, Eif4e, Elk1, Eif4e2, Prkag2, Mapk9, Calm2, Grb2, Sos2 \\
\hline $\begin{array}{l}\text { Protein processing in } \\
\text { endoplasmic reticulum }\end{array}$ & $\begin{array}{c}\text { Nploc4, Hspa8, Hspa1I, Hsph1, Capn2, Man1a2, Ube2j2, Mapk9, } \\
\text { Eif2ak2 }\end{array}$ \\
\hline Spliceosome & Hspa8, Hspa1I, Thoc3, Snrpd1, Ncbp1, Ism6, Pcbp1, Plrg1, Thoc4 \\
\hline $\begin{array}{l}\text { Ubiquitin mediated } \\
\text { proteolysis }\end{array}$ & $\begin{array}{l}\text { Skp2, Ube2q1, Ube2j2, Pias1, Anapc1, Anapc10, Ube2l3, Cdc26, } \\
\text { Cdc20 }\end{array}$ \\
\hline Proteasome & Psme3, Pomp, Psma1, Psmd14 \\
\hline ErbB signaling pathway & Mapk1, Map2k4, Pak2, Abl2, Elk1, Mapk9, Grb2, Sos2 \\
\hline $\begin{array}{l}\text { Neurotrophin signaling } \\
\text { pathway }\end{array}$ & Mapk1, Ywhaq, Ntf4, Nfkbie, Mapk9, Calm2, Grb2, Sos2 \\
\hline p53 signaling pathway & Chek2, Ccnb1, Ei24, Cdk2, Zmat3 \\
\hline Adherens junction & Mapk1, Yes1, Vcl, Ctnnd1, Tcf7 \\
\hline Chronic myeloid leukemia & Mapk1, Ctbp1, Hdac1, Grb2, Sos2 \\
\hline Categoria - KEGG & Genes hipoexpressos \\
\hline Parkinson's disease & $\begin{array}{c}\text { Cox6a2, Cyc2, Ndufs2, Ube2g2, Ube2l6, Ndufa12, Ndufa6, } \\
\text { Ndufv3, Ndufa3 }\end{array}$ \\
\hline Mineral absorption & Slc31a1, Slc39a3, Slc26a6, Hmox2 \\
\hline $\begin{array}{l}\text { Cytosolic DNA-sensing } \\
\text { pathway }\end{array}$ & Ripk3, Ifna4, RGD1562552, Polr3g \\
\hline $\begin{array}{l}\text { Pantothenate and CoA } \\
\text { biosynthesis }\end{array}$ & Coasy, Ppcs, Enpp3 \\
\hline Protein export & Srp19, Srpr, Sec61g \\
\hline Riboflavin metabolism & Acp5, Enpp3 \\
\hline
\end{tabular}




\section{Quadro S4 - Genes diferencialmente expressos enriquecidos em GO no intervalo de 6 horas de tratamento com Ang II.}

Processo Biológico - GO

Genes hiperexpressos

protein phosphorylation

negative regulation of apoptosis

positive regulation of apoptosis

proteasomal ubiquitindependent protein catabolic process

negative regulation of cell proliferation

cell cycle

cell division

nervous system development

DNA repair

actin cytoskeleton organization

DNA replication

protein ubiquitination

Mitosis

RNA splicing
Chek2, Nek2, Wnk1, Mapk1, Cdk5, Map4k3, Camk1, Cdk12, YEs1, Ccnb1, Dyrk1a, Map2k4, Pak2, Sgk1, Tbk1, Lrrk2, Stk36, Abl2, Pxk, Mst4, Nek6, Spag9, Cdc7, Vrk1, Cdk2, Pik3r4, Mapk9, Eif2ak2

Dffa, II6r, Serbp1, Glp1r, Smo, Fnta, Accn1, Fignl1, Gata6, Hells, Htt, Skp2, Sgk1, Hdac1, Apbb2, Serpinb9, Pea15a, Taf9, Rtn4, Twist1

Dffa, Cdk5, Aldh1a3, Map2k4, Gata6, Skp2, Ing4, Sav1, Apbb2, RGD1309922, Top2a, Mapk9, Eif2ak2

Bub1b, Ccnb1, Psme3, Ube2v2, Psmd5, Psma1, Irrk2, Sumo1, Fbxl5, Psmd14, Anapc1, Anapc10, Trim13, Cdc26, Taf9, Cdc20, Ppp2r5c, Gipc1

Phb2, Cd9, Igfbp5, Tinf2, Ing4, Hdc1, Sav1, Lrrk2, Brip1, Cdkn2c, Eif2ak2, Dlc1, Slc9a3r1, Mfn2, Inppl1, Ppp2r5c

Ccna2, Clasp2, Mapk1, Cdk5, Kif2c, Smc3, Arhgef2, Nek6, Spast, Cdk2, Cdc26, Calm2, Cdc20, Mlh1

Ccna2, Clasp2, Cdk5, Kif2c, Ccnb1, Smc3, Arhgef2, nek6, Top2a, Spast, Cdk2, Cdc26, Cdc20, Top1

Myo1b, Camk1, Dyrk1a, Accn1, Ube2v2, Dpf3, Lrrk2, Ophn1, Spast, Kctd11, LOC606294, Rtn4, Nrn1, Ppp1r9b

Polk, Wrnip1, Ube2v2, Polq, Fbxo18, Rbbp8, Fto, Smc3, Pole, Rev3I, Recql, Rnf168, Mlh1, Parg

Cdk5, Mk1, Sipa1l1, Coro1b, Capzb, Abl2, Ophn1, Ehd2, Vasp, Dlc1, Slc9a3r1, Cap1, Capza1

Wrnip1, Map2k4, Polq, Mcm4, Ing4, Pole, Rev3l, Recql, Cdc7, Cdk2, Helb, Top1

Rnf34, Skp2, Rnf2, Fbxl5, Anapc1, Anapc10, Rfws3, Ube2I3, Trim13, Cdc26, Rnf168, Ccnb1, Psme3, Psmd5, Psma1, Irrk2, Psmd14, Tbc1d7, Cdc20

Clasp2, Kif2c, Ccnb1, Jtb, Smc3, Arhgef2, Nek6, Cdk2, Cdc26, Cdc20

Cdk13, Snrpd1, Cd2bp2, Ncbp1, Hnrnpa2b1, Srek1, Plrg1, Thoc4, Polr2f 


\begin{tabular}{|c|c|}
\hline Processo Biológico - GO & Genes hipoexpressos \\
\hline apoptosis & $\begin{array}{c}\text { Psmd9, Acsbg1, Ripk3, Prkcb, Cycs, Aqp2, Ncstn, Psmg2, Actc1, } \\
\text { Fastk, Arhgef4, Ciapin1, Plekhf1, Trim39, Traf2, Aen, Itgb3bp, Scrip, } \\
\text { Pdcd2, Dapk3, Aifm1, Plg }\end{array}$ \\
\hline protein transport & $\begin{array}{c}\text { Pgap2, Arfgap1, Abra, Vps36, Snx17, Rabif, Chmp2b, Chmp7, } \\
\text { Efcab4b, Arfgap3, Gorasp1, Vps33b, Pex14, Snap23, Scamp2, Vps25, } \\
\text { LOC681989, Fxc1, Rab27b, Sec31a }\end{array}$ \\
\hline intracellular protein transport & $\begin{array}{c}\text { Vamp1, Abra, Ipo4, Napg, Ipo7, Srpr, Snupn, Tom112, Tom1, Sar1a, } \\
\text { Xpo5, Scamp2, LOC683402 }\end{array}$ \\
\hline & Zfp91, Ube2g2, Rnf146, Uhrf2, Traf2, Tri32, Klhl21, Cbll1, Mdm2, \\
\hline ubiquitin-dependent protein & $\begin{array}{l}\text { Ube3a, Herc6, Anapc13 } \\
\text { Usp2, Usp4, Usp15, Rnf146, Uhrf2, Trim32, Mdm2, Ube3a, Herc6, }\end{array}$ \\
\hline catabolic process & Usp48 \\
\hline response to oxidative stress & Abcc1, Coq7, Cycs, Ndufs2, Ndufa12, Ppp1r15b, Lias, Ndufa6, Hmox2 \\
\hline vesicle-mediated transport & $\begin{array}{c}\text { Arfgap1, Vamp1, Sar1a, Vamp4, Arfgap3, Vps33b, Snap23, } \\
\text { LOC683402, Sec31a }\end{array}$ \\
\hline protein targeting & Optn, Srp19, Strada, Mdm2, Srpr, Xpo5, Pmpcb, Pex14, Fxc1 \\
\hline $\begin{array}{l}\text { positive regulation of cell } \\
\text { migration }\end{array}$ & Abcc1, Acp5, Trim32, Cbll1, Srpx2, Cxcl16, Ager, Vegfa \\
\hline cytoskeleton organization & Cdc42bpa, Uxt, Bbs4, Tekt4, Tubgcp2, MAST1, Ablim2, Trpv4, Rhoq \\
\hline
\end{tabular}


Quadro S5 - Genes diferencialmente expressos enriquecidos em KEGG no intervalo de 3 horas de tratamento com Ang II e Losartan.

\begin{tabular}{|c|c|}
\hline Categoria - KEGG & Genes hiperexpressos \\
\hline Metabolic pathways & $\begin{array}{c}\text { Ndst2, Hsd17b1, B3gnt1, Polrf3f, Etnk1, Rdh12, Chpf, } \\
\text { Pigu, Alg11, Alg9, Rfk, Rpe }\end{array}$ \\
\hline Lysosome & Mcoln1, Aga, Abca2 \\
\hline Acute myeloid leukemia & Myc, Rps6kb2 \\
\hline Steroid hormone biosynthesis & Sts, Hsd17b1 \\
\hline N-Glycan biosynthesis & Alg11, Alg9 \\
\hline Categoria - KEGG & Genes hipoexpressos \\
\hline Cell cycle & Chek2, Cdc25b, Rp53, Anapc5, Mcm5, Smc1a \\
\hline p53 signaling pathway & Chek2, Tp53, Tsc2 \\
\hline $\begin{array}{l}\text { Amino sugar and nucleotide } \\
\text { sugar metabolism }\end{array}$ & Gale, Amdhd2, Gmppa \\
\hline beta-Alanine metabolism & Acadm, Aldh2 \\
\hline Propanoate metabolism & Acadm, Aldh2 \\
\hline $\begin{array}{l}\text { Glycine, serine and threonine } \\
\text { metabolism }\end{array}$ & Shmt2, Gcat \\
\hline $\begin{array}{l}\text { Vasopressin-regulated water } \\
\text { reabsorption }\end{array}$ & Dctn6, Dynll1 \\
\hline DNA replication & Mcm5, Pola1 \\
\hline
\end{tabular}


Quadro S6 - Genes diferencialmente expressos enriquecidos em GO no intervalo de 3 horas de tratamento com Ang II e Losartan.

\begin{tabular}{|c|c|}
\hline Processo Biológico - GO & Genes hiperexpressos \\
\hline $\begin{array}{c}\text { protein transport } \\
\text { positive regulation of apoptosis } \\
\text { steroid metabolic process } \\
\text { inflammatory response } \\
\text { tumor necrosis factor-mediated signaling pathway } \\
\text { positive regulation of cell migration } \\
\text { intracellular protein kinase cascade }\end{array}$ & $\begin{array}{c}\text { Lman1, Unc50, Mcoln1, Tram1, Atg9a } \\
\text { Jak2, Myc, TIr4, Stk4 } \\
\text { Lcat, Sts, Hsd17b1, Scap } \\
\text { Tnfrsf1b, Tnfrsf4, Tlr4, Jak, Ccl24, Zyx, Cd276 } \\
\text { Tnfrsf1b, Jak2, Tnfrsf4 } \\
\text { Jak2, Ccl24, Lamb1, Ccl2 } \\
\text { Jak2, Stk4 }\end{array}$ \\
\hline Processo Biológico - GO & Genes hipoexpressos \\
\hline $\begin{array}{c}\text { cell cycle / division and mitosis } \\
\text { regulation of cell cycle } \\
\text { DNA repair } \\
\text { carbohydrate metabolic process } \\
\text { protein homooligomerization } \\
\text { cell migration } \\
\text { negative regulation of signal transduction }\end{array}$ & $\begin{array}{c}\text { Cdc25b, Avpi1, Ppp1c, Anapc5, Kifc1, Mtus1, } \\
\text { RGD1306730, Smc1a, Arl2, Mlh1 } \\
\text { Cdc37, Tp53, Tsc2, Bop1 } \\
\text { Fbxo18, Kctd13, Smc1a, Mlh1, Pola1 } \\
\text { Gale, Ppp1c, Amdhd2, Chst5 } \\
\text { Acadm, Tsc2, Kctd13, Shmt2 } \\
\text { Bcar1, Kctd13, Gsk3a, Bambi } \\
\text { Tsc2, Erbb3, Gsk3a, Rfng }\end{array}$ \\
\hline $\begin{array}{l}\text { DNA damage response, signal transduction } \\
\text { resulting in induction of apoptosis }\end{array}$ & Chek2, Tp53, Mlh1 \\
\hline $\begin{array}{l}\text { circadian rhythm } \\
\text { insulin receptor signaling pathway }\end{array}$ & $\begin{array}{c}\text { Nfil3, Erbb3, Arntl } \\
\text { Eif4ebp1, Bcar1, Gsk3a }\end{array}$ \\
\hline $\begin{array}{l}\text { anaphase-promoting complex-dependent } \\
\text { proteasomal ubiquitin-dependent } \\
\text { protein catabolic process }\end{array}$ & Psmd9, Psme3, Anapc5 \\
\hline $\begin{array}{l}\text { neuroblast proliferation } \\
\text { TOR sianaling cascade }\end{array}$ & Tp53, Racgap1, Sox2 \\
\hline $\begin{array}{l}\text { positive regulation of epithelial } \\
\text { to mesenchymal transition }\end{array}$ & Wwtr1, Bambi \\
\hline cytokinesis & Incenp, Racgap1 \\
\hline $\begin{array}{c}\text { Rho protein signal transduction } \\
\text { negative regulation of Wnt receptor signaling } \\
\text { pathway }\end{array}$ & $\begin{array}{l}\text { Kctd13, Cdc42ep1 } \\
\text { Tsc2, Sox2 }\end{array}$ \\
\hline
\end{tabular}


Quadro S7 - Genes diferencialmente expressos enriquecidos em KEGG no intervalo de 6 horas de tratamento com Ang II e Losartan.

Categoria - KEGG

RNA transport

Cell cycle

Peroxisome

Pyrimidine metabolism

p53 signaling pathway

Proteasome

Riboflavin metabolism

Homologous recombination

RNA polymerase
Genes hiperexpressos

Eif4e, Ube2i, Pop4, Nup35, Gemin6, Pigz, Gemin2

Chek1, Ccne1, Cdc45, Mad211, Gadd45b

Pxmp4, Pex19, Eci2, Pex11b

Uck1, Cmpk2, Polr3k, Polr3gl

Chek1, Ccne1, Gadd45b

Psmb9, Psbm4, Psmb1

Acp5, Acp6

Rad54b, Rpa2

Polr3k, Polr3gl
Categoria - KEGG

Focal adhesion

Regulation of actin cytoskeleton

Chemokine signaling pathway

Lysosome

Axon guidance

PPAR signaling pathway

Adherens junction

Aminoacyl-tRNA biosynthesis

Biosynthesis of unsaturated fatty acids

Vitamin digestion and absorption

\section{Genes hipoexpressos}

Bcar1, Ptk2, Itgb4, Pak1, Myl9, Flnb, Itgb6, Actn4, Vegfa

Bcar1, Ptk2, Itgb4, Pak1, Myl9, Itgb6, lqgap1, Actn4

Plcb1, Stat3, Bcar1, Ptk2, Pak1, Gngt2

Ctsh, Cdig2, Gga2, Ctsa, Abcb9

Ptk2, Pak1, Sema3c, Sema3f, Slit2

Acsl1, Scd4, LOC681458, Gk

Smad2, Ssx2ip, Iqgap1, Actn4

Aars, Farsb, Wars

Scd4, LOC681458

Tcn2, Cubn 


\section{Quadro S8 - Genes diferencialmente expressos enriquecidos em GO no intervalo de 6 horas de tratamento com Ang II e Losartan.}

\begin{tabular}{|c|c|}
\hline Processo Biológico - GO & Genes hiperexpressos \\
\hline protein ubiquitination & $\begin{array}{l}\text { Psmb9, Arrb2, Ube2i, Ube2t, Psmb4, Rnf168, } \\
\text { Psmb1, Arrb2, Mad211, Birc5 }\end{array}$ \\
\hline $\begin{array}{l}\text { proteasomal ubiquitin-dependent } \\
\text { protein catabolic process }\end{array}$ & $\begin{array}{l}\text { Psmb9, Arrb2, Ube2i, Mad2l1, Jkamp, Psmb4, } \\
\text { Psmb1 }\end{array}$ \\
\hline mitotic cell cycle & Eif4e, Psmb9, Mad2l1, Psmb4, Birc5, Psmb1 \\
\hline DNA repair & Chek1, Gen1, Alkbh2, Rpa2, Rnf168 \\
\hline regulation of cell growth & Cd44, Exosc9, Ccdc85b, Ulk1, Zfp639 \\
\hline cell division & Ube2i, Ccne1, Cdc45, Spast, Birc5 \\
\hline cellular process involved in reproduction & Sep15, Arrb2, Nkx2-1, Syt6, Zfp639 \\
\hline cell cycle process & Psmb9, Mad2l1, Psmb4, Birc5, Psmb1 \\
\hline response to peptide hormone stimulus & Prss8, Aqp2, Prlh, Birc5 \\
\hline Processo Biológico - GO & Genes hipoexpressos \\
\hline signal transduction & $\begin{array}{c}\text { Chd4, Cdh13, Grin2c, Ngfr, ll1rl1, Itpr3, Xpr1, } \\
\text { Aars, Srebf2, Arhgap28, Fert2, Scara5, Ngf, } \\
\text { lqgap1, Vapb, Arhgap10 }\end{array}$ \\
\hline cell differentiation & $\begin{array}{c}\text { Egr2, Klf4, Sox9, Ngfr, Plcb1, Ptk2, Jag1, } \\
\text { Clip3, Cd276, Slit2, Zmiz1, Sohlh1, Srf, Ascl1, } \\
\text { Dhh }\end{array}$ \\
\hline response to organic substance & $\begin{array}{l}\text { Abcc4, Cdh13, Stat3, Acsl1, Fosl1, Ptk2, Sdc2, } \\
\text { Smad2, Pak1, Srebf2, Ngf, Slit2, Pea15a, } \\
\text { Hspd1, GK } \\
\text { Nra1 Sox9, Abcc4 Cdh13, Nafr. Irs1.Ptk2 }\end{array}$ \\
\hline regulation of cell proliferation & $\begin{array}{c}\text { Ngf, Zmiz1, Sox4, Apln, Nolc1, Vegfa, Nr2f2, } \\
\text { Klf4, Jag1 }\end{array}$ \\
\hline negative regulation of apoptosis & $\begin{array}{l}\text { Nrg1, Sox9, Cdh13, Ngfr, Dnajb9, Ptk2, Lrp1, } \\
\text { Ngf, Pea15a, Sox4, Hspd1, Ascl1, Vegfa }\end{array}$ \\
\hline response to stress & $\begin{array}{l}\text { Adh5, Ubqln1, Dnajb9, Sdc2, Aars, Pak1, } \\
\text { Scara5, Sox4, Vapb, Actn4, Hspd1, Gk, Vegfa }\end{array}$ \\
\hline regulation of signal transduction & $\begin{array}{l}\text { Klf4, Avpi1, Cdh13, Ngfr, Irs1, Jag1, Smad2, } \\
\text { Pak1, Ngf, Sulf2, Slit2, Ascl1, Vegfa }\end{array}$ \\
\hline cell surface receptor linked signaling pathway & $\begin{array}{l}\text { Plcb1, Spn, Stat3, Acsl1, Bcar1, Gfra1, Il1rap, } \\
\text { II1r11, Itgb4, Fcgr2b, Itgb6, Slit2 }\end{array}$ \\
\hline cell adhesion & $\begin{array}{c}\text { Nrg1, Cdh13, Bcar1, Ptk2, Itgb4, Fert2, Pcdh9, } \\
\text { Ssx2ip, Itgb6, Omd }\end{array}$ \\
\hline
\end{tabular}


Quadro S9 - Genes diferencialmente expressos enriquecidos em KEGG no intervalo de 3 horas de tratamento com Ang II e PD123319.

\begin{tabular}{|c|c|}
\hline Categoria - KEGG & Genes hiperexpressos \\
\hline $\begin{array}{l}\text { Purine metabolism } \\
\text { Steroid hormone biosynthesis }\end{array}$ & $\begin{array}{l}\text { Gucy1b2, Pfas, Polr2i } \\
\text { Ugt1a6, Cyp1b1 }\end{array}$ \\
\hline Retinol metabolism & Ugt1a6, Dhrs3 \\
\hline $\begin{array}{l}\text { Metabolism of xenobiotics } \\
\text { by cytochrome P450 }\end{array}$ & Ugt1a6, Cyp1b1 \\
\hline Drug metabolism - other enzymes & Ugt1a6, Ces2a \\
\hline N-Glycan biosynthesis & Ganab, Man1c1 \\
\hline Categoria - KEGG & Genes hipoexpressos \\
\hline Pathways in cancer & $\begin{array}{c}\text { Pik3ca, Itgb1, Myc, Prkca, Fgf9, Axin2, Hdac1, } \\
\text { Cbl, Birc5, Sos2 }\end{array}$ \\
\hline MAPK signaling pathway & $\begin{array}{c}\text { Dusp6, Myc, Prkca, Fgf9, Rasa1, Pak2, Ppp3r1, } \\
\text { Rras, Sos2 }\end{array}$ \\
\hline Regulation of actin cytoskeleton & $\begin{array}{c}\text { Ppp1r12a, Pik3ca, Itgb1, Fgf9, Pak2, Itga4, Rras, } \\
\text { Sos2 }\end{array}$ \\
\hline ErbB signaling pathway & Pik3ca, Myc, Prkca, Hbegf, Areg, Pak2, Cbl, Sos2 \\
\hline Focal adhesion & $\begin{array}{l}\text { Ppp1r12a, Pik3ca, Itgb1, Prkca, Pak2, Itga4, } \\
\text { Sos2 }\end{array}$ \\
\hline Axon guidance & Itgb1, Rasa1, Pak2, Ppp3r1 \\
\hline VEGF signaling pathway & Pik3ca, Prkca, Ppp3r1 \\
\hline
\end{tabular}




\section{Quadro S10 - Genes diferencialmente expressos enriquecidos em GO no intervalo de 3 horas de tratamento com Ang II e PD123319.}

\begin{tabular}{|c|c|}
\hline Processo Biológico - GO & Genes hiperexpressos \\
\hline $\begin{array}{l}\text { cell differentiation } \\
\text { angiogenesis }\end{array}$ & $\begin{array}{l}\text { Igfbp3, Gpsm1, Ggn, Sox18, Lrp6, Nr0b1, Mdk } \\
\text { Ecm1, Cyp1b1, Ccl24, Sox18, Pnpla6, Ccl2 }\end{array}$ \\
\hline response to peptide hormone stimulus & Ugt1a6, Pnmt, Lrp6, Nr0b1 \\
\hline embryo development & Foxn3, Ccno, Foxj2, Fzd2 \\
\hline $\begin{array}{c}\text { regulation of sequence-specific DNA binding } \\
\text { transcription factor activity }\end{array}$ & Lrp6, Foxn3, Foxj2, Nr0b1 \\
\hline vasculature development & Cypb1, Sox18, Fzd2 \\
\hline canonical Wnt receptor signaling pathway & Lrp6, Fzd2, Bambi \\
\hline Processo Biológico - GO & Genes hipoexpressos \\
\hline cell differentiation & Dusp6, Bzw2, Fgf9, Snai2, Rasa1, Axin2, Areg, \\
\hline negative regulation of apoptosis & $\begin{array}{l}\text { Ppp3r1, Rora, Runx2, Sh2b3, Fhl2, Ctgf, Dhh } \\
\text { Pik3ca, Myc, Serbp1, Rasa1, Zc3hc1, Hdac1, Api5, }\end{array}$ \\
\hline positive regulation of cell proliferation & $\begin{array}{c}\text { Itgb1, Myc, Prkca, Hbegf, Fgf9, Areg, Hdac1, Etv5, } \\
\text { Aggf1. Runx2, Ctaf }\end{array}$ \\
\hline ossification & $\begin{array}{c}\text { Mmp13, Fgf9, Snai2, Axin2, Areg, Impad1, Nab2, } \\
\text { Runx2, Fhl2, Ctgf }\end{array}$ \\
\hline negative regulation of cell proliferation & $\begin{array}{c}\text { Gtpbp4, Itgb1, Prkca, Emd, Eif2ak1, Axin2, Hdac1, } \\
\text { Eif2ak2 }\end{array}$ \\
\hline cell adhesion & $\begin{array}{c}\text { Cdh17, Itgb1, Rasa1, Tnfrsf12a, Aggf1, Itga4, Ctgf, } \\
\text { Cdhr1 }\end{array}$ \\
\hline canonical Wnt receptor signaling pathway & Emd, Fgf9, Snai2, Axin2, Hdac1, Lats2, Cyld \\
\hline regulation of signal transduction & Dusp6, Zfp91, Prkca, Fgf9, Slc7a1, Hdac1, Runx2 \\
\hline regulation of cell proliferation & Myc, Prkca, Hbegf, Emd, Fgf9, Etv5, Eif2ak2 \\
\hline aging & Lonp1, Prkca, Eno3, Canx, Ctgf, Tfrc \\
\hline dephosphorylation & Dusp6, Ppp1r12a, Acp2, Ppp3r1, Impad1, Pdp1 \\
\hline regulation of mitotic cell cycle & Myc, Cyld, Brd4, Birc5, Pim3, LOC690728 \\
\hline
\end{tabular}




\section{Quadro S11 - Genes diferencialmente expressos enriquecidos em KEGG no intervalo de 6 horas de tratamento com Ang II e PD123319.}

\begin{tabular}{|c|c|}
\hline Categoria - KEGG & Genes hiperexpressos \\
\hline $\begin{array}{c}\text { Peroxisome } \\
\text { mTOR signaling pathway }\end{array}$ & $\begin{array}{l}\text { Phyx, Pex19, Paox, Crot, Mlycd } \\
\text { Cab39l, Eif4b, Ulk1, Rps6kb2, Pgf }\end{array}$ \\
\hline Cytosolic DNA-sensing pathway & Nfkbia, Mavs, Ikbke, Polr2e \\
\hline Sphingolipid metabolism & Sphk1, Galc, Ppap2a \\
\hline $\begin{array}{l}\text { SNARE interactions in vesicular } \\
\text { transport }\end{array}$ & Vamp1, Vamp4, Stx8 \\
\hline Categoria - KEGG & Genes hipoexpressos \\
\hline MAPK signaling pathway & $\begin{array}{l}\text { Dusp6, Bndf, Hspa8, Ppp3ca, Prkca, Gadd45a, Mapkapk2, } \\
\text { Pak1, Mecom, Dusp16, Rapgef2, Ngf, Rps6ka5, Rras2, Max, } \\
\text { Stk3 }\end{array}$ \\
\hline Pathways in cancer & $\begin{array}{c}\text { Cdk6, Pik3ca, Prkca, Stat5b, Arnt, Igf1r, E2f3, Skp2, Mecom, } \\
\text { Pias1, Traf3, Rad51, Max, Bid, Ccdc6 }\end{array}$ \\
\hline Focal adhesion & $\begin{array}{c}\text { Pik3ca, Prkca, Bcar1, Igf1r, Capn2, Mylk3, Pak1, Myl9, Vcl, } \\
\text { Dock1, Myl12b, Ccnd2 }\end{array}$ \\
\hline Regulation of actin cytoskeleton & $\begin{array}{c}\text { Pik3ca, Bcar1, Myh9, Mylk3, Pak1, Myl9, Vcl, Dock1, Rras2, } \\
\text { Myl12b, Nckap, Msn }\end{array}$ \\
\hline Cell cycle & $\begin{array}{c}\text { Cdk6, Cdc25a, Gadd45a, E2f3, Skp2, Ccna, Mcm4, Cdc6, } \\
\text { Anapc10, Ccnd2, Mad111 }\end{array}$ \\
\hline Neurotrophin signaling pathway & $\begin{array}{l}\text { Pdk1, Pik3ca, Bdnf, Camk2d, Irs1, Mapkapk2, Ngf, Rps6ka5, } \\
\text { Sh2b3 }\end{array}$ \\
\hline RNA transport & $\begin{array}{c}\text { Eif4ebp1, Eif4e, Eif4a1, Nup93, Eif3a, Tmem48, Eif5, Pigz, } \\
\text { Nup98 }\end{array}$ \\
\hline ErbB signaling pathway & Eif4ebp1, Pik3ca, Camk2d, Prkca, Stat5b, Hbegf, Pak1 \\
\hline p53 signaling pathway & Cdk6, Serpine1, Gadd45a, Ei24, Ccnd2, Bid \\
\hline Glioma & Cdk6, Pik3ca, Camk2d, Prkca, Igf1r, E2f3 \\
\hline Apoptosis & Cflar, Pik3ca, Ppp3ca, Capn2, Ngf, Bid \\
\hline $\begin{array}{l}\text { Progesterone-mediated oocyte } \\
\text { maturation }\end{array}$ & Pik3ca, Cdc25a, Igf1r, Ccna1, Anapc10, Mad111 \\
\hline Ribosome biogenesis in eukaryotes & Cirh1a, Mphosph10, Utp15, Heatr1, Xrn2, Gar1 \\
\hline mTOR signaling pathway & Eif4ebp1, Eif4e, Pik3ca, Prkaa1 \\
\hline Circadian rhythm - mammal & Npas2, Csnk1e, Csnk1d, Bhlhe40 \\
\hline Steroid biosynthesis & Hsd17b7, Nsdhl, Soat1 \\
\hline
\end{tabular}




\section{Quadro S12 - Genes diferencialmente expressos enriquecidos em GO no intervalo de 6 horas de tratamento com Ang II e PD123319.}

\begin{tabular}{|c|c|}
\hline Processo Biológico - GO & Genes hiperexpressos \\
\hline $\begin{array}{l}\text { positive regulation of } \\
\text { cell proliferation }\end{array}$ & $\begin{array}{l}\text { Sphk1, Il11, Casr, Erbb2, Stat5a, Ccnb1, Rogdi, Cd47, Myd88, } \\
\text { Tbx18, Sox4, Cyba }\end{array}$ \\
\hline protein transport & $\begin{array}{c}\text { Dnajc14, Exoc3, Dnm2, Mcoln1, Nutf2, Tmed3, Duoxa1, Chmp1a, } \\
\text { Gorasp1, Psen2, Sec16b }\end{array}$ \\
\hline brain development & $\begin{array}{c}\text { Stxbp3, Sphk1, Dmbx1, Tmem57, Bbc3, Fzd1, Tulp3, Cdk5rap3, } \\
\text { Sharpin, Synj2 }\end{array}$ \\
\hline regulation of cell proliferation & Sphk1, Ndrg2, Erbb2, Mitf, Nfkbia, Ifi30, Creb3, Myd88, Cyba \\
\hline $\begin{array}{l}\text { vesicle-mediated transport } \\
\text { inflammatorv resnonse }\end{array}$ & Stxbp3, Vamp1, Sar1a, Vamp4, Chmp1a, Stx8, Sec16b \\
\hline $\begin{array}{l}\text { cell surface receptor linked } \\
\text { signaling pathway }\end{array}$ & Erbb2, Fcer1g, Cd47, Myd88, Itga10, Plxnb1 \\
\hline $\begin{array}{l}\text { I-kappaB kinase/ } \\
\text { NF-kappaB cascade }\end{array}$ & Nfkbia, Ltbr, Myd88, Mavs, Ikbke, Sharpin \\
\hline $\begin{array}{l}\text { chromatin modification } \\
\text { innate immune response }\end{array}$ & $\begin{array}{l}\text { Apbb1, Suv420h2, Smarcal1, Smarcd2 } \\
\text { Myd88, Sp110, Mavs, Cyba }\end{array}$ \\
\hline $\begin{array}{l}\text { response to stress / } \\
\text { oxygen levels }\end{array}$ & Ccnb1, Ndrg1, Bbc3, Asl \\
\hline Processo Biológico - GO & Genes hipoexpressos \\
\hline protein phosphorylation & $\begin{array}{c}\text { Nek2, Cdk6, Pdk1, Pik3ca, Cdk12, Prkca, Igf1r, Mapkpk2, Mylk3, } \\
\text { Pak1, Lmtk2, Lats2, Mast4, Pdik1l, Rps6ka5, MSt4, Nek7, Vrk2, } \\
\text { Riok3, Mdfic, Epha2, Bmx, Gsk3a, Csnk1e, Csnk1d, Stk3, Prkaa1, } \\
\text { Hipk2, Plk2 }\end{array}$ \\
\hline signal transduction & $\begin{array}{c}\text { Stat5b, Il1rl1, Ahr, Rtkn, Ngf, Asap1, Traf3, Siva1, Syde1, Rras2, } \\
\text { Stard13, Gsk3a, Pdpn, Ramp2, Arhgap17, Stk3, Arhgap10, Akap12, } \\
\text { Gnb5, Plk2, Hmga2, Bpm7 }\end{array}$ \\
\hline apoptosis & $\begin{array}{l}\text { Slah2, Hip1, Ahr, Nlrp3, Rtkn, Ngf, Fam82a, Nlrp1a, Bag4, Aen, } \\
\text { Siva1, Pea15a, Epha2, Dap, Bid, Stk3 }\end{array}$ \\
\hline protein transport & $\begin{array}{c}\text { Stxb1, Myh9, Abra, Nup93, Lmtk2, Ipo9, Rufy1, Tmem48, Rab6b, } \\
\text { Pex14, Timm10, Vps45, Arf2, Nup98, Sec31a }\end{array}$ \\
\hline $\begin{array}{l}\text { negative regulation of } \\
\text { apoptosis }\end{array}$ & $\begin{array}{c}\text { Cflar, Pik3ca, Bdnf, Stat5b, Igf1r, Skp2, Btg2, Rtkn, Ngf, Ndufaf4, } \\
\text { Siva1, Pea15a, Hipk3, Rtn4, Cat, Serpine1, Accn1, Cd44, Nes, } \\
\text { Fignl1, Btg2, Ung, Tfap4, Wfs1, Bmp7 }\end{array}$ \\
\hline $\begin{array}{l}\text { response to organic } \\
\text { cyclic compound }\end{array}$ & $\begin{array}{l}\text { Dusp6, Bdnf, Eno2, Prkca, Cd44, Ahr, Homer1, Btg2, Ngf, Atf1, Ctgf, } \\
\text { Ccdnd2 }\end{array}$ \\
\hline regulation of cell proliferation & $\begin{array}{l}\text { Cdk6, Serpine1, Prkca, Stat5b, Hbgef, Plcd3, Skp2, Mecom, Atp2b1, } \\
\text { Mfn2, Bid, Rbpj }\end{array}$ \\
\hline $\begin{array}{l}\text { cell cycle } \\
\text { response to estrogen stimulus }\end{array}$ & $\begin{array}{c}\text { Cdk6, Siah2, Cdc25a, Ppp6c, Ahr, Spc25, Ccdc99, Thap1, Specc1l, } \\
\text { Pdpn, Rgs2 } \\
\text { Eno2, Serpine1, Prkca, Stat5b, Ahr, Rbbp5, Ramp2, Ctgf, Ccnd2, } \\
\text { Bid, Bmp7 }\end{array}$ \\
\hline
\end{tabular}


DNA replication regulation of apoptosis nervous system development response to stress
Rfc2, Cdc25a, Kctd13, Mcm4, Clspn, Pole, Blm, Cdc6, Ctgf, Nup98 Cflar, Hip1, Mllt11, Deptor, Mst4, Traf3, Pea15a, Bid, Wfs1 Bdnf, Hbgef, Nes, Kat2a, Fnbp1I, Epha2, Slc7a5, Pdpn, Bhlhe40, Rtn4

Bdnf, Cat, Hspa8, Serpine1, ppp3ca, Ahr, Homer1, Rps6ka5, Pdpn, Ctgf 